\begin{abstract}
Universidade de São Paulo
Faculdade de Filosofia, Letras e Ciências Humanas

Departamento de Letras Modernas

Programa de Pós-Graduação em Língua, Literatura e Cultura Italianas

Antonio Carlos Olivieri

Princípios da ciência moral de Antonio Rosmini: tradução de uma obra filosófica italiana para o português
\end{abstract}

Versão corrigida

São Paulo

2016 
ANTONIO CARLOS OLIVIERI

\title{
Princípios da ciência moral de Antonio Rosmini: tradução de uma obra filosófica italiana para o português
}

Dissertação e tradução apresentadas à Faculdade de Filosofia, Letras e Ciências Humanas da Universidade de São Paulo para a obtenção do título de Mestre

\author{
De acordo: \\ Orientador: Prof. Dr. Luiz Antônio Lindo
}

Versão Corrigida

São Paulo

2016 


\section{Informação}

A versão original se encontra disponível na Biblioteca da Faculdade de Filosofia e Ciências humanas, bem como na Biblioteca Digital de Teses e Dissertações da USP. 
A todos os ítalo-paulistanos com que convivi desde a infância e especialmente a dona Lida Palmieri di Dalia, ex-colega de trabalho na sucursal de São Paulo da ANSA - Agenzia Nazionale Stampa Associata, que, desde 1991, muito me honra com sua carinhosa amizade 


\section{Agradecimentos}

Expresso aqui minha profunda gratidão ao meu orientador, Prof. Dr. Luiz Antônio Lindo, que aceitou meu projeto e acreditou em minha capacidade de realizá-lo, contribuindo para isso com a sua leitura atenta, comentários e sugestões. 


\title{
Resumo
}

Este trabalho se compõe de duas partes. Primeiramente, um estudo introdutório sobre o autor, Antonio Rosmini, sobre sua obra filosófica e, mais especificamente, sobre o livro Principi della scienza morale, que, na segunda parte, traduzimos para o português. $\mathrm{Na}$ introdução, expomos brevemente o sistema filosófico rosminiano e o contextualizamos no âmbito histórico-filosófico. Além disso, apresentamos o percurso por nós desenvolvido para obter uma tradução filologicamente correta do texto original, incluindo um breve glossário dos termos filosóficos empregados pelo autor.

\begin{abstract}
This work is composed of two parts. Firstly, there is an introductoty study on the author, Antonio Rosmini, on his phylosophical system and, more specifically, on the book Principi della scienza morale, which we have translated to Portuguese, in the second part. In the introduction, we expose briefly the rosminian phylosofical system and we place it in its historical-phylosofical context. Furthermore, we show the path we've followed to reach a phylologically correct translation from the original text, including a brief glossary of phylosophical terms employed by the author.
\end{abstract}




\section{Sumário}

\section{$1^{\text {a }}$. Parte - Estudo sobre o autor e a obra}

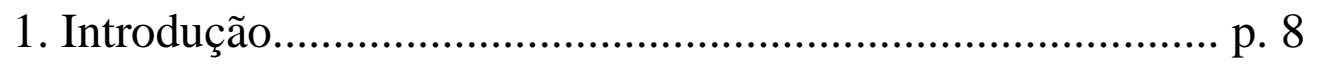

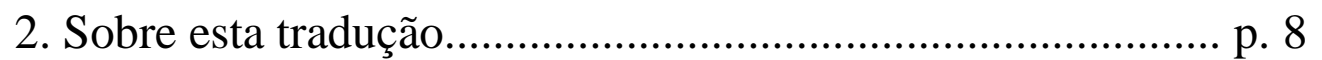

$3 \mathrm{O}$ autor e a importância de traduzi-lo..................................... p. 14

$3.1 \mathrm{O}$ sistema filosófico rosminiano........................................... p. 20

3.2 Novo ensaio sobre a origem das ideias............................... p. 22

4. Ética ou filosofia da prática.................................................. p. 26

4.1 Ethos social e debate ético contemporâneo.......................... p. 30

4.2 Os Princípios da ciência moral............................................. p. 32

4.3 A atualidade da ética rosminiana.......................................... p. 39

4.4. Coda filosófico-literária........................................................ p. 44

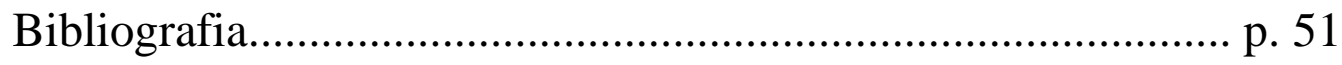

$2^{\text {a }}$. Parte - Tradução

Princípios da ciência moral...................................................... p. 54

Anexo I - Glossário................................................................ p. 208

Anexo II - Principi della scienza morale (texto original) ....... p. 216 


\section{Introdução}

O intuito de nosso trabalho é apresentar ao leitor de língua portuguesa o pensamento de um filósofo italiano importante e original: o padre Antonio Rosmini (Rovereto, 1787 - Stresa, 1855), que desenvolveu uma extensa obra filosófica e teológica, além de ter tido importante participação política nos debates do período imediatamente anterior à Unificação da Itália, conhecido como Risorgimento (Ressurgimento). Não é possível afirmar com absoluta certeza, mas até onde conseguimos pesquisar apenas uma pequena obra sua, Ragionamento sul comunismo e socialismo, teve edição para o português, pela extinta Editora Convívio, em 1967.

Optamos pela tradução de Principi della scienza morale, reputada a mais importante de suas obras sobre ética, dada a necessidade dos estudos éticos na sociedade contemporânea. Para tanto, utilizamos o texto estabelecido no volume 23 da edição das obras completas de Rosmini publicadas conjuntamente pelo Istituto di Studi Filosofici (Roma), o Centro di Studi Rosminiani (Stresa) e a Città Nuova Editrice (Roma).

Neste estudo introdutório, vamos expor, inicialmente, algumas questões relativas à tradução de um texto filosófico e mais especificamente da obra que escolhemos. Em seguida, traçaremos um síntese biográfica do autor e faremos um estudo expositivo de seu sistema filosófico e uma análise dos Princípios da ciência moral, com o intuito de mostrar sua atualidade e justificar nossa tradução.

\section{Sobre esta tradução}

Conforme Bassnett (2003), numa obra já clássica dos estudos da tradução:

"De acordo com uma abordagem estritamente linguística, a tradução consistia em transferir o 'sentido' contido num conjunto de signos linguísticos para outro conjunto de signos linguísticos, através do recurso competente ao dicionário e à gramática; contudo o processo envolve 
também um vasto conjunto de critérios extralinguísticos" [Op. cit., p. 35].

Particularmente, no caso de uma obra filosófica, talvez se possa dizer que entre os critérios extralinguísticos se encontra a essência do discurso filosófico: o pensamento do autor. Nesse sentido, são especialmente válidas as palavras do humanista Leonardo Bruni Aretino, em "Da tradução correta" (Scientia Traduccionis, 2011), acerca da tradução filosófica, segundo o qual "o bom tradutor se transformará com toda a mente, alma e determinação no autor primeiro do escrito e de modo algum o transformará tratando de expressar a forma, a postura e a textura do discurso, a cor e os diversos matizes. (...) deverá se adaptar ao estilo de cada um”.

Em outras palavras, não cabe ao tradutor de um tex to filosófico tomar liberdades com as palavras do autor, de quem ele deve ser eminentemente apenas um porta-voz, passando para sua língua com exatidão o que foi dito pelo autor, cuja soberania para expressar seu pensamento tem de ser reverenciada e obedecida.

Para tanto, a pesquisa realizada acerca do livro que traduzimos precisou incidir fundamentalmente nos conceitos que Rosmini apresenta e articula. Contudo, apesar de o conceito ser normalmente indicado por um nome ou palavra, ele "não é o nome, já que diferentes nomes podem exprimir o mesmo conceito, ou diferentes conceitos podem ser indicados, por equívoco, pelo mesmo nome" (Abbagnano, 2000). De fato, há tradutores de filosofia que afirmam trabalhar "com conceitos e argumentos e não com palavras" (Daiber, 2007). Não chegamos, absolutamente, a esse extremo, mas reconhecemos que o principal problema com que nos defrontamos encontrava-se no aspecto conceitual do texto, expresso evidentemente por meio do vocabulário.

Ao mesmo tempo, não se pode deixar de mencionar a extensão dos períodos ou dos parágrafos rosminianos, que sempre requerem do tradutor uma especial atenção para evitar equívocos. Nesse sentido, numa tentativa de resolver o problema, recorremos inicialmente a cotejar o original com a sua tradução inglesa ${ }^{1}$, cujo caráter é, antes de tudo, didático, visando deixar claro o pensamento do autor, sem grande preocupação com a literalidade textual. Se isso nos ajudou, gradualmente, a entender as ideias de Rosmini, muito pouco nos serviu para realizar a tradução para o português com a fidelidade aludida por Bruni.

\footnotetext{
${ }^{1}$ http://www.rosmini-in-english.org/Webpe/PE_Conts.htm
} 
Para dar um exemplo concreto da dificuldade enfrentada, vamos transcrever um parágrafo do texto rosminiano, seguido de sua tradução para o inglês, a qual, posteriormente, traduziremos ipsis litteris para o português para evidenciar a defasagem linguística existente entre o original italiano e a versão inglesa. Não há nisso, fique claro, nenhuma intenção de desmerecer o trabalho do tradutor britânico, cujo objetivo não era o mesmo do nosso, mas o de simplificar didaticamente a linguagem do autor para tornar seu pensamento mais acessível aos leitores anglófonos:

a) Texto original:

"Questa osservazione sola rimuove grande quantità d'equivoci, e recide un gran numero d'errori, ne' quali s'involgono altre teorie, che divinizzano l'uomo o l'abbrutiscono. Conciossiaché alcuni, osservando l'eccellenza e l'infalibilità del lume della ragione, confondono questo lume colla ragione, che é la potenza che l'usa, e rendono la ragione umana baldanzosa e superba, l'uomo legislatore e Dio, nell'universo morale; alcuni altri osservando all'opposto la fallacia della ragione umana, e disconescendo quell'elemento divino che in lei risplende (l'idea dell'essere), calcano l'uomo stesso al basso, condannandolo o a un perpetuo errore, o ad andar tentone nelle tenebre in cerca della verità senza mai sicurezza di rinvenirla, né levandolo a vero stato morale. E se non consente la brevitá di quest'opera, ch'io persegua questi erronei sistemi, che rovesciano quinci e quindi negli estremi viziozi; non traslascerò tuttavia di accenarli, e di discreverli siccome scogli, accioché possano essere evitati."

b) Tradução inglesa:

"This observation alone eliminates many of the equivocations and errors of other theories, which make human beings either gods or animals. If reason, which is the power using the light, is confused with the light, it falsely takes on the excellence and infallibility of the light. Reason becomes proud and self-reliant; the human being becomes both legislator and God in the moral universe. On the other hand, to note the fallibility of reason but ignore its divine element (the idea of 
being) is to debase human beings by denying them a true moral state. They are either condemned to perpetual error, or to groping in the darkness for the truth they can never be certain of finding."

\section{c) Versão para o português da tradução inglesa:}

"Essa observação somente elimina muitos dos equívocos e erros das outras teorias, que fazem dos seres humanos deuses ou animais. Se a razão, que é a potência usando a luz, é confundida com a luz, ela falsamente adquire a excelência e a infalibilidade da luz. A razão se torna orgulhosa e autoconfiante; o ser humano se torna ao mesmo tempo legislador e Deus no universo moral. Por outro lado, perceber a falibilidade da razão, mas ignorar seu elemento divino (a ideia do ser) é rebaixar os seres humanos por lhes negar um estado moral verdadeiro. Ambas estão condenadas ao erro perpétuo, ou a tatear na escuridão pela verdade, cuja certeza de encontrar jamais terão."

Apesar da falta de literalidade, foi a partir da tradução inglesa, contudo, que começamos a nos aproximar do pensamento rosminiano, produzindo um texto em português que parecia mais próximo do original italiano, mas ainda deixava a desejar quanto à literalidade que desejávamos alcançar. Segue a primeira versão que fizemos do mesmo parágrafo:

\section{d) Primeira versão de nossa tradução:}

“Essa observação por si só afasta um grande número de equívocos e revoga um grande número de erros nos quais incorrem outra teorias que ou divinizam ou embrutecem o homem. É assim que alguns, observando a excelência e a infalibilidade do lume da razão, confundem esse lume com a razão, que é a potência que o usa, e tornam a razão humana temerária e soberba, bem como o homem legislador e Deus no universo moral. Alguns outros, observando ao contrário a falácia da razão humana e desconhecendo aquele elemento divino que nela resplende (a idéia do ser), calcam o homem lá para baixo, condenando-o a um erro perpétuo ou a andar às 
apalpadelas, procurando nas trevas a verdade, sem nunca ter a certeza de encontrá-la. Mas, se não consente a brevidade desta obra que eu esmiuce esses sistemas errôneos que caem nesses extremos viciosos, não devo deixar de apontá-los e descrevêlos, para que possam ser evitados.”

Esse procedimento, apesar de algumas ligeiras alterações no texto italiano, nos permitiu, num primeiro momento, avançar na tradução, para depois chegarmos a uma versão definitiva, mais afinada com o discurso original, mantendo ao máximo o objetivo de uma tradução literal:

\section{e) Versão definitiva de nossa tradução:}

"Só essa observação afasta um grande número de equívocos e revoga um grande número de erros nos quais incorrem outras teorias que ou divinizam o homem ou o embrutecem. É assim que alguns, observando a excelência e a infalibilidade do lume da razão, confundem esse lume com a razão, que é a potência que o usa, e tornam a razão humana temerária e soberba, o homem legislador e Deus no universo moral; alguns outros, observando ao contrário a falácia da razão humana e desconhecendo aquele elemento divino que nela resplende (a ideia do ser), calcam o homem lá para baixo, condenando-o a um erro perpétuo ou a andar às apalpadelas nas trevas em busca da verdade, sem nunca ter a certeza de encontrá-la, nem o levando a um verdadeiro estado moral. Mas, se não consente a brevidade desta obra que eu persiga esses sistemas errôneos que despejam uns e outros em extremos viciosos, não me eximirei, todavia, de apontá-los e descrevêlos, para que possam ser evitados."

A propósito, cremos ser adequado mencionar aqui uma obra da Antiguidade, que também nos serviu de baliza no que se refere à tradução de um texto filosófico. Trata-se de "As núpcias de Filologia e Mercúrio", de Marciano Capella, retórico latinoafricano do século $\mathrm{V}$, que nos apresenta o seguinte mito: os deuses do Olimpo, preocupados com o celibato prolongado de Mercúrio, divindade-símbolo da linguagem e de suas capacidades significativas e criadoras, resolveram discipliná-lo, providenciando seu casamento com uma virgem mortal, Filologia, que representa a 
expressão ordenada e disciplinada do logos. Desse modo, segundo Capella, consagrouse para a eternidade a união definitiva entre o potencial infinito da linguagem e sua administração expressiva cientificamente ordenada. Em outras palavras, acreditamos que ao tradutor cabe o papel filológico da ordenação do texto na língua de chegada, desviando-se o mínimo possível em relação ao da língua de partida.

Evidentemente, o fato de as duas línguas em questão aqui serem derivadas do Latim facilitou nossa tarefa, de modo que mais uma vez voltamos ao ponto de partida: compreender o pensamento do autor e as circunstâncias em que sua obra foi produzida revelou-se mais importante do que os aspectos propriamente linguísticos da tradução, ainda que deles não descurássemos. Enfim, concordamos com Bassnett (op. cit. p. 129) que há:

"Uma estreita relação entre a teoria e a prática da tradução", que "o tradutor que não faz nenhuma tentativa para entender o como que subjaz ao processo de tradução é como o condutor de um automóvel que não faz a mínima ideia do que faz o veículo andar".

Contudo, no nosso caso específico, era essencial, antes de mais nada, conhecer o modelo e o ano do veículo, descobrir as engrenagens que colocavam em marcha seu motor, para poder dar a partida e seguir a estrada até o fim, sem grandes incidentes de percurso.

Por razões de ordem editorial, optamos por apresentar a pesquisa conceitual que procedemos sob a forma do breve glossário que segue abaixo, uma vez que os Princípios da ciência moral contam com um grande número de notas de rodapé de autoria do próprio Rosmini, algumas das quais muito extensas. Assim, se apuséssemos juntamente com as notas do autor as nossas próprias explicações conceituais, que muitas vezes também não são breves, forçaríamos a interrupção da leitura da obra com uma frequência que perturbaria o acompanhamento da evolução dos raciocínios do roveretano. Assim, organizamos as notas de rodapé do seguinte modo:

1) as notas do autor são indicadas no texto por algarismos arábicos e vêm apresentadas ao final de cada artigo em que se subdividem os capítulos do livro, sempre precedidas da abreviatura N.A. (Nota do Autor).

2) As notas de nossa autoria, que inserimos no corpo do texto rosminiano, são indicadas por algarismos romanos. Quando se referem a um conceito, limitam-se a indicar a página em que ele se encontra no Glossário, que se encontra ao fim da 
tradução. Em outros casos, quando são breves referências aos títulos de obras citadas pelo autor ou a qualquer outra informação sumária que auxilie a compreensão do leitor, nossas notas se intercalam com as notas do autor, vindo ao final dos artigos, sempre indicadas por algarismos romanos e precedidas pela abreviatura N.T. (Nota do Tradutor).

3) Além disso, como em alguns poucos casos as notas do autor exigiram algum esclarecimento ou referência, precisamos recorrer à inclusão de uma N.T. no interior de uma N.A. e, nesses casos, nós a indicamos com um ou mais asteriscos (*).

Temos certeza de que esse procedimento editorial há de mostrar sua lógica e praticidade quando o leitor for se deparando com cada uma das notas em seu devido local de inserção.

Finalmente, cumpre mencionar a existência no original de conjunções, pronomes e advérbios em desuso no italiano contemporâneo e que exigiram pesquisa em diversos dicionários, especialmente o de Battaglia (2004). A título de exemplo, podemos apresentar:

1) Accioché: conj. a fim de que, para que;

2) Adunque: conj. e adv. portanto, pois, logo, por isso;

3) Conciossiaché: conj. sendo que, desde que;

4) Costoro: pron. demonstrativo plural, esses;

5) Egli: pron. pessoal de $3^{\mathrm{a}}$. pessoa, ele;

6) Eziandioché: se bem que, mesmo que;

7) Imperciocché: conj. porque, por causa de;

8) Ivi: ali, lá;

9) Perocché: conj. em razão de, porque;

10) Posciaché: conj. pois que, já que

\section{O autor e a importância de traduzi-lo}

Ao propor a tradução para o português de um livro sobre Ética de um filósofo italiano da primeira metade do século XIX, de quando a Itália ainda nem se unificara, como é o caso de Antonio Rosmini, não se pode deixar de formular algumas questões iniciais e básicas como: por que traduzir esse filósofo? Em que medida seus pensamentos - e, no caso de Rosmini, melhor seria falar de seu sistema filosófico, permanecem atuais e têm algo a dizer ao leitor brasileiro contemporâneo? Contudo, 
antes de responder essas questões, outra pergunta, ainda mais preliminar, se coloca, como aquela feita na introdução da "História da filosofia italiana" (Garin, 1966, p. 22]: é lícito falar de filosofias nacionais, dada uma suposta antinomia entre a "universalidade" da filosofia e a "particularidade" de um pensamento nacional? Não estaria a história da filosofia mais ligada ao tempo do que ao espaço?

De fato, Garin prossegue afirmando que não se pode falar de uma matemática grega, árabe, indiana ou chinesa, mas só de uma única matemática e, se é assim, essa concepção não valeria também para a filosofia? Até certo ponto, sim, mas a filosofia, por sua própria constituição como disciplina, "tem sempre ligações com situações históricas definidas e, à realidade do filosofar, sempre importará uma referência específica a dimensões espaço-temporais, a uma determinada comunidade espiritual entre os homens de um determinado tempo e lugar".

Por isso - e acrescentando ao raciocínio de Garin o de outro destacado estudioso de filosofia da Itália contemporânea:

"não se faz justiça a um filósofo se as suas afirmações são isoladas do contexto biográfico, psicológico, cultural, social e literário em que elas adquiriram significado, julgandoas somente em si mesmas como enunciados isolados a qualquer referência ao contexto" (Abbà, 2011, p.58).

Disso decorre que, ainda antes de responder as questões inicialmente propostas, cumpre apresentar ao leitor brasileiro o autor da obra que agora se traduz, o que se pode começar a fazer pela transcrição da abertura do verbete sobre Antonio Rosmini, na Enciclopedia Italiana Treccani, redigido em 2012 por Luciano Malusa, professor de filosofia da Universidade de Gênova:

"Antonio Rosmini-Serbati é considerado o maior filósofo italiano do século XIX. Não importa qual seja o juízo sobre o seu sistema, assentado na tradição platônico-cristã, o papel que teve na cultura italiana é relevante. A vastidão de suas pesquisas, a coerência da constituição especulativa, a complexidade do pensamento são dotes reconhecidos até por filósofos 'laicos' como Bertrando Spaventa, Francesco Fiorentino, Donato Jaja e Giovanni Gentile. Seus méritos no pensamento e na ação em favor da causa da independência nacional tornaram-se mais claros na atualidade: em papel 
diplomático, cumpriu em 1848 uma importante negociação com o fim de realizar a unificação dos Estados da Itália de forma federativa" 2 .

Após este juízo de valor altamente favorável e no intuito de se aprofundar o conhecimento sobre o autor avaliado, o melhor a fazer agora é passar aos fatos, apresentando-os em um breve perfil biográfico rosminiano. Antonio Rosmini nasceu em 23 de março de 1797, em Rovereto, cidade de população italiana, no Tirol. Na época, fazia parte do Império Austríaco. Hoje é uma comuna da região italiana do Trentino-Alto Adige. De família aristocrática e católica, desde a juventude Rosmini manifestou sua vocação para o sacerdócio. Depois dos estudos primários e secundários, seguiu para a Universidade de Pádua para estudar Teologia. Em 1821, ainda antes de se graduar, ordenou-se padre.

Desde o início de sua formação intelectual, mostrou-se avesso às consequências da Revolução Francesa na Europa, de modo geral, e contrário às ideias do Empirismo e do Iluminismo. Contudo, não era um reacionário. Politicamente, esteve alinhado com os liberais italianos de sua época. Filosoficamente, é melhor defini-lo com suas próprias palavras: "Para se restaurar o amor e o respeito à filosofia, entendo que será necessário, por um lado, um retorno aos ensinamento dos antigos; por outro, dar a esses ensinamentos os benefícios do método moderno" (Teodiceia, art. 148, apud Clearly, 1992). Sua filosofia, contudo, será tratada com maior minúcia mais à frente.

Ainda no plano biográfico, devemos dizer que Rosmini não se dedicou a levar uma vida exclusivamente contemplativa e reflexiva. Foi um homem de ação e, enquanto escrevia suas primeiras obras filosóficas, entre 1829 e 1831, também passou a desenvolver o projeto de fundação de uma nova ordem religiosa: o Instituto da Caridade, que só veio a receber plena aprovação papal em 1839. Inicialmente, o Instituto funcionou junto à igreja do Sacro Monte Calvário, da comuna de Domodossola, expandindo-se depois para a comuna de Stresa, ambas no Piemonte. A ordem, segundo Rosmini, tem como "bandeira aquela que é dada por nosso Mestre: a universalidade da caridade". Por essa expressão, o autor entendia, conforme dispõe na Regra de Vida do Instituto, três tipos de caridade:

- A temporal ou material, que se traduz na ajuda aos necessitados.

\footnotetext{
2 http://www.treccani.it/enciclopedia/antonio-rosmini-serbati_\%28IlContributo-italiano-alla-storia-del-Pensiero:-Filosofia\%29/
} 
- A espiritual ou moral, que visa a salvação do homem pela difusão da fé e dos sacramentos.

- A intelectual, que deve libertar a mente das trevas da ignorância e iluminá-la com a luz da verdade.

Ao estudioso do filósofo, chama a atenção esse terceiro tipo, pois a ele Rosmini dedicou uma extensa obra, cumprindo aliás uma orientação recebida do papa Pio VIII (cujo pontificado, vale a pena informar, foi brevíssimo, de março de 1829 a dezembro de 1830): "é vontade de Deus que vos ocupeis de escrever livros: tal é a vossa vocação... Tende certeza: poderei ajudar muito mais o próximo ocupando-vos em escrever, do que exercendo qualquer outra obra do sacro ministério" (apud Garin, 1966, p. 1105). Assim, a filosofia para Rosmini faz parte de sua missão religiosa. No entanto, desde já, deve ficar claro que a religiosidade cristã a orientar seu pensamento não compromete o caráter iminentemente filosófico de seus escritos. Vale para o roveretano o que argumenta Abbá (2011, p. 57) sobre a filosofia de modo mais geral:

"Mesmo quando - como veremos - pressupõe teses cristãs, a investigação continua sendo filosófica, porque argumenta dialeticamente em favor da sensatez de pressupor tais teses; e, em filosofia, uma argumentação sempre deve ser exposta na mesma intensidade com que outras filosofias pretendem refutá-la".

Retomando, contudo, o perfil biográfico que aqui se esboça, cumpre-nos mencionar ainda que o Instituto da Caridade incomodou a Companhia de Jesus, provavelmente por esta considerar a nova ordem como concorrente. Os jesuítas criticaram a doutrina rosminiana e publicaram obras condenando-a. A disputa intensificou-se e só se conteve - ao menos por algum tempo - por ordem expressa do papa Gregório XVI, que pontificou entre 1831 e 1846. Antes de seguir em frente, porém, não se pode deixar de mencionar que, além da disputa com os jesuítas, Rosmini entrou em polêmica com outro importante filósofo e patriota italiano do Risorgimento, Vincenzo Gioberti, que em 1841 publicou a obra "Os erros filosóficos de Antonio Rosmini”. Mas a polêmica e o debate faziam parte da natureza do roveretano, de quem se disse: "vossa vida literária é uma contínua e implacável invectiva..." (Apud Garin, 1966, p. 1112).

Com a entronização de um novo papa, Pio IX, tido como liberal, Rosmini acreditou poder levar adiante algumas propostas de reforma da Igreja e, nesse sentido, 
publicou, em 1848, o opúsculo "As cinco chagas da Igreja católica”. Neste livro, o autor denuncia a separação do clero dos fieis na liturgia, a educação insuficiente dos sacerdotes, a falta de unidade entre os bispos, a interferência da autoridade política nas nomeações episcopais e os problemas derivados da posse de bens materiais pela Igreja. A obra foi uma das mais traduzidas entre as escritas pelo autor, sendo vertida para o alemão, o catalão, o espanhol, o inglês, o romeno e o russo. Foi publicada simultaneamente com um livro político de Rosmini, “A Constituição segundo a Justiça Social", que confrontava as constituições da França revolucionária e a da Inglaterra, esboçando uma Constituição para uma futura monarquia parlamentar italiana.

Com este trabalho, alinhava-se a liberais como o escritor Alessandro Manzoni, o político e educador Rafaello Lambruschini, o político e escritor Cesare Balbo, o linguista Niccolò Tommaseo e até a Vincenzo Gioberti, integrando a corrente de pensamento conhecida como Cristianismo liberal, para a qual os direitos de liberdade política, de consciência e de pensamento brotavam de valores cristãos. Contudo, essas duas obras rosminianas reacenderam a rivalidade que o sacerdote sofria no interior da Igreja e ambas acabaram sendo incluídas no Index Librorum Prohibitorum, em 1849.

Convém lembrarmos aqui que os anos de 1848 e 1849, na península Itálica, são marcados pela primeira guerra de Independência conta o Império austríaco. A guerra à Áustria se estendeu de março de 48 a março de 49. Foi declarada pelo rei Carlo Alberto di Savoia, do Reino da Sardegna, que incluía o ducado de Savoia, o condado de Nizza, a Ligúria e Piemonte. Rosmini foi enviado a Roma pelo Reino Sardo, para cooptar o pontífice para a causa da Independência e da unificação italiana, que, segundo o projeto rosminiano, se daria sob a forma de uma confederação de Estados, mantendo-se assim a soberania temporal do papa nos Estados Pontifícios. Todavia a proposta não agradou nem os sardos nem o papa.

De qualquer modo, a relutância de Pio IX de aderir à causa italiana e o clima revolucionário que vigorava na região resultou na impossibilidade de o pontífice se manter em Roma, onde uma revolução estabeleceu uma República de breve duração, praticamente durante o ano de 1849. Pio IX fugiu para uma fortaleza na comuna de Gaeta, no Reino das Duas Sicílias, de onde, apelando aos próprios austríacos, aos franceses e aos espanhóis, foi restabelecido no trono pontifício em 1850. Solidário ao papa, Rosmini o acompanhou no exílio, mas foi rapidamente excluído da corte pontifícia pelo cardeal Giacomo Antonelli, secretário de Estado de Pio IX, que queria 
encarregar-se pessoalmente definir a política da Santa Sé, colocando-a em direção contrária às conquistas liberais e à unidade nacional.

Rosmini retornou a Stresa, onde se dedicou especialmente a rebater os renovados ataques que passou a sofrer por parte dos jesuítas. No entanto, Pio IX renovou o preceito de silêncio estabelecido por seu antecessor, Gregório XVI, e encarregou a Congregação do Índice a examinar toda a obra rosminiana até então publicada, o que se estendeu de 1851 a 1854 e terminou com a aprovação da obra do roveretano. Rosmini, empenhado na escritura de sua obra metafísica Teosofia, mal teve tempo de comemorar a vitória, pois acometido por uma doença insidiosa no fígado, perdeu paulatinamente as forças e faleceu em $1^{\circ}$. de julho de 1855 , aos 58 anos.

Para piorar, com a publicação de uma série de obras póstumas de Rosmini, ocorreu uma nova reavaliação de seu pensamento e 40 de suas teses foram consideradas contrárias ao pensamento tomista, que o papa Leão XIII definira como a filosofia oficial das escolas católicas. Em decorrência disso, as teses rosminianas passaram a ser olhadas com suspeição, como doutrinas de cunho eclético e de caráter fortemente filosófico e especulativo.

Assim, o Decretum Post Obitum, emitido por Leão XIII em 1887, condenou o pensamento rosminiano, que só veio a ser reabilitado pela Congregação para a Doutrina da Fé, sob a direção do então cardeal Joseph Ratzinger ${ }^{3}$, em 1998, depois de o papa João Paulo II ter declarado na encíclica Fides et Ratio ${ }^{4}$, de 1998, que Rosmini se encontrava "entre os pensadores mais recentes nos quais se realiza um fecundo encontro entre o saber filosófico e a palavra de Deus" (§ 74). Com isso, abriu-se caminho para sua beatificação, o que veio a ocorrer no papado de Bento XVI, em 18 de novembro de 1897.

Este breve esboço biográfico é suficiente para esclarecer o papel de Rosmini enquanto personagem da história italiana e da Igreja católica. Deixa muito a desejar, no entanto, do ponto de vista filosófico e é nele que se concentrará agora o nosso foco, destacando, em primeiro lugar, uma observação que sobre ele faz o historiador da filosofia Michelle Federico Sciacca, realçando o caráter atual do pensamento rosminiano:

3

http://www.vatican.va/roman_curia/congregations/cfaith/documents/rc_con_cfaith_do c_20010701_rosmini_po.html

${ }^{4}$ http://w2.vatican.va/content/john-paul-ii/pt/encyclicals.index.html 
“Certamente, sua formação intelectual [de Rosmini] tem raízes na tradição e na metafísica platônico-agostiniana, além de aristotélico-tomista, mas isso não o impede de repensála originalmente e de recolocá-la no interior da problemática do pensamento moderno. Nem ele se opõe a este último, fideisticamente, só porque contrastante com a verdade de sua fé católica; opõe-se a ele em nome de uma investigação especulativa mais exigente e crítica. [...] Rosmini tinha a mente aberta a todas as sugestões da filosofia e sabia bem que uma restauração espiritualista, após a evolução do pensamento europeu a partir do Renascimento e de Descartes, não podia significar um retorno ao pensamento tradicional. Era necessário adotar as exigências do pensamento moderno, repensar por meio dele o pensamento tradicional e, com base nesse repensamento, recolocar em questão as conclusões a que haviam chegado quatro séculos de especulação.” (Sciacca, 1955, p. 13, tradução nossa.)

\subsection{O sistema filosófico rosminiano}

Em segundo lugar, o próprio Rosmini nos apresenta um versão abreviada de sua concepção de filosofia em seu Discorso degli studi dell'Autore, datado de 1850, que resumiremos a seguir. Segundo o que ali se encontra, a filosofia tem duas funções em particular: 1) combater o erro; 2) sistematizar a verdade. Só desse modo ela pode servir de base à ciência e à teologia. No combate ao erro, portanto, o filósofo deve distinguir claramente as formas das dificuldades, que podem variar ao longo do tempo ou das gerações, e formular questões que possibilitem ver seus antecedentes históricos e os princípios envolvidos em sua solução. Ninguém, afirma Rosmini, erra porque quer e a tradição filosófica constitui uma lição objetiva do movimento em direção à verdade e à eliminação do erro. De qualquer modo, não é possível ir em frente sem errar, pois o movimento rumo a níveis mais altos de reflexão enfrenta desníveis.

O combate ao erro, contudo, é um aspecto negativo da filosofia e que não lhe é suficiente. $\mathrm{O}$ aspecto positivo é o da sistematização da verdade, ou seja, mostrar como 
se passa de princípios gerais e autoevidentes para níveis mais particulares do conhecimento. Rosmini considera que o conhecimento evolui do geral para o particular e dá para isso um exemplo retirado do cotidiano: a mãe ensina para o filho pequeno, em primeiro lugar, o termo flores, só depois ela irá ensinar termos mais específicos como rosa, margarida ou violeta. Ora, o ser é a mais geral de todas as noções e o princípio universal do conhecimento, do que decorre que a verdade é o ser enquanto conhecido. Por outro lado, a aplicação universal da noção de ser nunca é vista de imediato e completamente, mas é preferível procurá-la do que acumular fatos desconexos.

Enquanto base para os vários ramos do conhecimento, a filosofia é o estudo das "razões finais" de todas as coisas. Para atingi-las, ela deve partir da noção geral de "ser", que é o "lume da razão" humana, e não pela devoção ao ato de raciocinar, como fizeram os racionalistas, empiristas e iluministas, que, somando a isso o sensismo e a atitude subjetivista, deslocaram o eixo da filosofia para o âmbito do erro. Entretanto, não é esse o momento de aprofundar a crítica rosminiana a essas escolas filosóficas, o que será feito logo mais, ao tratarmos de duas obras específicas do autor, Il nuovo saggio sull'origine delle idee e Principi della scienza morale, esta última o objeto de nossa tradução. Por enquanto, lembremos somente que Rosmini vê na fragmentação da filosofia e na sua consequente separação da teologia uma consequência do pensamento sensista. Na sua concepção, entretanto, a Revelação não cancela a razão. Antes, a enobrece e, de resto, a filosofia colabora com a teologia, demostrando de modo lógico certas verdades da fé.

Finalmente, Rosmini advoga a liberdade da filosofia, considerando o erro o seu principal obstáculo. Segundo o roveretano, o erro decorre fundamentalmente do assentimento a preconceitos errôneos e não a quaisquer preconceitos. Pelo contrário, raciocinamos, de modo geral, de maneira preconceituosa ou preconceitual, com juízos formados apressadamente que nos permitam agir e responder as exigências da vida e a grande quantidade de coisas com que nos defrontamos; o filósofo deve, pois, examinar o preconceito e descobrir o que ele tem de verdade, de modo a estabelecer uma persuasão racional sobre o conhecimento que o preconceito traz. De resto, negar verdades não comprovadas, como as da fé, é anular a possibilidade de filosofar, pois é possível ter a solução para um problema, antes de conhecer as razões dessa solução.

Posto isto, a fé não é um empecilho à filosofia e nem só os descrentes podem filosofar. Além disso, sistemas filosóficos diferentes podem ser conciliados, desde que 
se baseiem em princípios verdadeiros e independentemente de suas diferenças acidentais. A conciliação depende exclusivamente da concordância de princípios. Com isso se encerra a exposição da visão que o próprio Rosmini expressa sobre a filosofia no Discorso degli studi dell'Autore. Agora, para complementar a compreensão desse sistema filosófico e, ao mesmo tempo, mostrá-lo em seu primeiro momento de construção, devemos nos ater à primeira obra filosófica rosminiana, Il nuovo saggio sull'origine delle idee, escrito mais de duas décadas antes do Discorso e publicado em 1830. Compreendê-la é indispensável para entender os Principi della scienza morale e mesmo para traduzi-los. Com esse intuito, seguiremos basicamente a exposição que Clearly (1992) fez do texto, acrescentando, porém, alguns excertos do próprio Rosmini.

\subsection{Novo ensaio sobre a origem das ideias}

Antes de mais nada, diga-se que o título do Nuovo saggio remete diretamente à obra de John Locke, An essay concerning the human understanding (normalmente traduzido por "Ensaio sobre o entendimento humano", sem o artigo indefinido que precede o substantivo "ensaio", em inglês). Assim, o ensaio de Rosmini é novo porque se contrapõe a um ensaio anterior. No entanto, não é somente o pioneiro da escola empírica britânica que o roveretano tem em mira, mas também seus seguidores como Condillac, Reid e Dugald Stewart, de um lado; bem como Kant, de outro. Para enfrentar esses expoentes do pensamento moderno, Rosmini se fundamenta na filosofia da Antiguidade: dos pré-socráticos a Platão e Aristóteles, assim como, no âmbito da filsofia cristã, em Agostinho, Tomás de Aquino e outros escolásticos.

Segundo Rosmini, para explicar os fatos relativos ao espírito humano, não podemos fazer nem menos suposições nem mais do que as necessárias para explicá-los. $\mathrm{Ou}$, em suas próprias palavras, no primeiro capítulo da obra:

"Os princípios que queremos ter diante de nossos olhos nesses nossos raciocínios são dois.

"Primeiro: 'Na explicação dos fatos do espírito humano não se deve presumir menos do que o necessário para explicá-los'.

“A razão disso é evidente: enquanto não assumir tudo o que é necessário, não se pode jamais afirmar ter chegado a uma razão suficiente, ou seja, uma razão que realmente explique. Assim, suponhamos, quem observa esses dois fatos da 
sensibilidade humana, a sensação das cores e a dos sons, e pretende explicá-las dando ao homem um só sentido, isto é, ou só a audição ou só a visão, ora, ele não pode dar a razão completa de ambos os fatos; pois se quiser reduzir ambos ao ver, jamais poderá fazer entender como os olhos sentem os sons; e se quiser reduzir tudo à audição, não há como explicar, de modo válido a sensação das cores.

“O segundo princípio é: 'Não se deve presumir mais do que o necessário para explicar os fatos ${ }^{5}$.

"Tudo o que se assume que é mais que necessário à explicação torna-se supérfluo e gratuito; o que significa dizer que, tão gratuitamente quanto se afirma, tão gratuitamente se pode refutar e negar. A título de exemplo, quem tomasse dois sentidos e os desse ao homem unicamente para explicar com eles uma única espécie de sensação tornar-se-ia ridículo, atribuindo a um único gênero de fatos duas razões, uma das quais se torna evidentemente supérflua e introduzida insensatamente".

Pois bem, tendo como base esses dois princípios, o roveretano considera Locke, Condillac, Reid e Stewart entre aqueles cuja explicação dos fatos é deficiente pois se baseia exclusivamente nas sensações; por outro lado relaciona Platão, Aristóteles, Leibniz e Kant entre aqueles cuja explicação peca, muitas vezes, pelo excesso. Por exemplo, Kant postula a existência de 12 categorias a priori do entendimento (basicamente relacionadas à quantidade, qualidade, relação e modalidade), além de duas formas de intuição (espaço e tempo). Para Rosmini, no entanto, o entendimento humano depende de uma única ideia inata ou a priori: a ideia do "ser". Sem ela, nada é inteligível, pois não podemos pensar o que não é. Por conseguinte, é pela ideia geral do "ser" e por suas determinações possíveis, trazidas pelos sentidos, que se podem explicar todos os princípios e ramificações do pensamento.

De resto, pode-se retirar tudo de qualquer pensamento, mas, mesmo assim, permanece sempre a ideia do "ser". Evidentemente, vamos nos limitar aqui à concepção de ser de acordo com Rosmini, uma vez que essa palavra "constitui tanto o termo mais utilizado pela filosofia quanto sua questão mais radical” [Zarader, 2007 - tradução nossa]. Rosmini considera que a ideia de "ser" possui os atributos divinos da

5 “É fácil perceber que esses dois princípios, considerados conjuntamente, são apenas o princípio da razão suficiente, dividido nas duas partes de que se compõe”. (Rosmini, 2003, p. 115) 
universalidade, infinidade, necessidade e possibilidade. Desse modo ela age na mente, mas não é parte dela: é uma luz intelectual, que ilumina, mas que se origina fora da mente. E ela ilumina sem revelar sua fonte, assim como a luz natural pode ser percebida sem que olhemos para o Sol. Mais que isso, ela é, nas palavras de Dante, "a luz entre a verdade e o teu intelecto" (Purgatório, VI, 45, tradução nossa).

A objetividade do "ser" é dada pelas sensações, que determinam a ideia do ser, que, por sua vez, é a forma do entendimento. Assim, o conhecimento consiste primeiramente na intuição do "ser” em geral e, em seguida, numa série de juízos ou percepções diretas, através das quais sujeitos inteligentes afirmam a existência real do que eles experimentam por meio dos sentidos. Essas percepções ou conhecimento direto não podem errar, embora a reflexão sobre eles e uma subsequente série de juízos possam se tornar uma fonte de erro. Em suma, Rosmini sustenta que o conhecimento básico, consistindo da ideia de "ser" e de suas determinações imediatas, fornece tudo o que é necessário para o pensamento objetivo. Contra os idealistas, ele reduz os requisitos formais do pensamento à intuição do "ser". Contra os sensistas, ele sustenta a incapacidade de os sentidos, exclusivamente, oferecerem ao pensamento mais do que a matéria de reflexão.

Portanto, a objetividade é essencialmente uma característica do que é conhecido. Certeza, sob o ponto de vista rosminiano, é uma característica da pessoa que conhece e pode ser definida como "uma persuasão firme e razoável que se conforma à verdade" (Rosmini, 2003, seção VI, cap. 1, § 1044, tradução nossa). Nesse sentido, podemos estar certos somente do conhecimento e não do erro, porque, de acordo com o filósofo, conhecer e conhecer a verdade são a mesma coisa. A pessoa que não conhece a verdade simplesmente não conhece. Por outro lado, não há dúvida de que é possível ser persuadido e firmemente persuadido do erro. Mas a persuasão racional do erro atingida pelo próprio raciocínio não é possível. Neste caso, ou a premissa está errada ou o raciocínio é falacioso. Por outro lado, a persuasão necessita firmeza. A certeza não é obtida sem energia dirigida à persuasão.

A certeza requer que saibamos que algo é verdadeiro, que é o que é, que estamos persuadidos de que é o que sabemos que é, e que temos as razões adequadas para nossa persuasão. E, precisamente porque o erro implica alterar o ser das coisas, o erro formal não pode se enraizar no intelecto, nem nos sentidos, nem na reflexão involuntária. Ele começa na vontade, a única faculdade humana capaz de conduzir a razão a inventar o que ela não vê ou a negar o que vê. Sob a pressão da vontade, a razão pode afirmar 
falsamente que o ser não é ou negar que o ser é. Mas deixemos de lado, por enquanto, qualquer consideração sobre a vontade, cujo papel na ética rosminiana supera o que tem na epistemologia.

Apenas, antes de prosseguir em direção à moral, tema deste estudo, é inevitável arriscar uma avaliação sobre o Nuovo saggio, livro que resumimos sumariamente. Nosso juízo de valor baseia-se, exclusivamente, sobre a validade do raciocínio que tecemos, cuja solidez cabe ao leitor avaliar. A nosso ver, ao responder a questão epistemológica - que se tornou o centro da filosofia após Descartes, os empiristas britânicos e Kant - com uma afirmação ontológica, Rosmini trouxe de volta o eixo da filosofia à questão do ser, à ontologia e à metafísica, com um enorme pioneirismo e com uma radicalidade que só encontrará paralelo em Heidegger, no século XX. Nesse sentido, a verdadeira dimensão de suas investigações filosóficas ainda não encontrou o seu devido lugar na história da filosofia.

Parece-nos que reforça esta nossa posição as seguintes avaliações:

1) "É dupla, portanto, a sua [de Rosmini] importância: uma nacional, enquanto contribui (juntamente com Galluppi) para fazer os italianos pensarem com a própria cabeça e se transportarem para um nível europeu; e uma outra universal, enquanto no interior do pensamento europeu, aprofunda a instância crítica, sob um novo plano, que consentia com a superação do epistemologismo, seja nas formas do empirismo e do racionalismo, seja naquela kantiana" (Sciacca, 1955, p. 13, tradução nossa).

2) "Seu grande mérito é repensar as exigências metafísicas do pensamento tradicional sob a base do princípio da autoconsciência redescoberto pelo pensamento moderno, de modo a construir criticamente um novo espiritualismo. Para cumprir esse dever, ele indaga a possibilidade de descobrir um ponto de vista especulativo tal que possa superar o empirismo, com seus desenvolvimentos sensistas e materialistas, e o idealismo, não só na forma 'empírica' de Berkeley, mas também nas formas transcendentais do criticismo a partir de Kant. Rosmini vê a realização desse fim condicionada à solução de um problema fundamental: a objetividade da consciência. 
(...) Portanto, a nosso ver, a teoria do conhecimento de Rosmini e para Rosmini tem dentro de si uma metafísica implícita, que permanece sempre seu primeiro problema, aquela metafísica espiritualista, que tanto sofrera nas teorias iluministas e a que Kant negou o título secular de "ciência"'. (Sciacca, 1955, p. 55/56, tradução nossa.)

Contudo, deixemos de lado hipóteses cuja demonstração ultrapassariam os limites não só deste trabalho, mas também da própria capacidade de seu autor, que só pôde pedir a Sciacca algum apoio. Passemos, pois, à perspectiva da Ética, refazendo a questão com que abrimos esta reflexão sobre a obra de Rosmini: por que traduzir para o portugês os Principi della scienza morale? O que eles têm de atual e em que medida contribuem com os debates atuais acerca da Ética? Infelizmente, a resposta às questões exige, como antes, outras digressões.

\section{4. Ética ou filosofia da prática}

Não se trata de fazer aqui uma história da Ética, a partir de Aristóteles, que a definiu e estabeleceu seus limites, mas de refletir sobre o que é a Ética ou filosofia moral, que tipo de investigação lhe cabe, quais seus pontos de partida e de chegada, e como procede para atingir os seus objetivos. Para tanto, tomaremos como base as reflexões feitas por Abbá (2011) nos três primeiros capítulos de sua obra sobre o tema. Segundo este autor, é evidente que, quando iniciamos uma pesquisa em filosofia moral, já possuímos previamente uma experiência moral, proveniente da relação com os outros e com nós mesmos. No entanto, essa experiência nos impõe questões, às quais não é nada simples responder.

Nestes termos, é inevitável que a pesquisa moral se inicie in media res, ou seja, com o veículo em andamento, de modo que constantemente tomaremos como ponto de referência nossa própria experiência moral pré-filosófica e, à luz dela, interrogaremos as filosofias morais já existentes, bem como podemos trilhar também o caminho inverso. Tendo essa circunstância em mente, podemos agora definir a experiência moral como uma prática, ou seja, o exercício do conhecimento voltado para o agir, o que consiste em deliberar sobre os prós e os contras das opções ao nosso dispor, com base em nossos valores pessoais ou compartilhados com um grupo social; ou ainda, em 
decidir com base em nossas emoções ou crenças e convicções; ou finalmente em avaliar e praticar a nossa própria ação.

A prática, ressalva Abbà, é eminentemente pessoal, mas, do ponto de vista da sua origem, aquela do grupo social antecede a da pessoa ou do indivíduo, que nasce no seio de uma comunidade, a qual já possui um ethos social, constituído pelos costumes compartilhados pelo grupo, aos quais se atém, e que regulamentam a prática individual dos seus integrantes. Mas o estudioso vai além nessa consideração sobre o ethos, de modo que preferimos transcrever suas próprias palavras:

"É decisivo reconhecer que os costumes dos grupos humanos se caracterizam por um sentido a eles imanentes, isto é, por uma racionalidade prática graças à qual um certo tipo constante de comportamento é exigido como idôneo para realizar certos fins compartilhados, para assegurar certos bens comuns, apreciados e desejados pelo grupo. (...) A racionalidade prática imanente ao ethos torna-se explicitamente reconhecível quando se expressa nas leis, nas normas, nas histórias, nas celebrações dos eventos e dos personagens que definem a identidade moral do grupo.” (Abbà, 2011, p. 28)

Pois bem, a sucessão das gerações exige que os novos membros do grupo sejam educados de modo a transmitir-lhes o ethos comunitário ou social. Por um lado, isso requer uma pedagogia impositiva, em que as normas são prescritas com autoridade e sancionadas por meio de incentivos e penalidades. Por outro, para efetivamente suscitar nos jovens uma consciência moral pessoal é forçoso também fazer recurso ao convencimento, mediante o debate e a argumentação. Ressalte-se que essa consciência moral pessoal é requerida para resolver os problemas específicos com que o indivíduo fatalmente se defronta em sua vida, como também pelos dilemas que se originam do pluralismo inerente ao ethos das sociedades em geral, as quais estão em constante evolução, em transformações cujo ritmo pode ser mais lento ou mais rápido, como comprova a História.

Evidentemente, podem surgir tensão e conflitos sociais entre o ethos social e a consciência pessoal, que, evidentemente, não se trata de um simples conflito de opiniões, como exemplifica o caso de Sócrates, condenado à morte pela pólis ateniense. De fato, os conflitos morais não são embates de pouca importância ou intensidade. Ao contrário, são frequentemente dramáticos, envolvendo as mais fortes emoções, sejam 
do grupo ou da pessoa consciente: a admiração ou a indignação, o elogio ou a repreensão, a gratidão e o rancor. Lembremos, a propósito, a compreensão do grande filósofo espanhol Ortega Y Gasset sobre a dramaticidade da vida humana, por não podermos nos separar de um mundo que não escolhemos para viver:

"Isto dá à nossa vida um gosto terrivelmente dramático. Viver não é entrar em um lugar previamente escolhido por gosto, como se escolhe um teatro depois de um jantar - senão que é encontrar-se, de pronto e sem saber como, caído, submerso e projetado em um mundo" (Ortega, 1997).

Portanto, "muito de nossa felicidade e de nossa miséria, da nossa prosperidade e da nossa ruína, da nossa salvação e da nossa perdição depende da boa e da má conduta de nós mesmos e dos outros" (Abbà, 2011, p. 34). Se uma filosofia moral anula a dramaticidade da prática moral suas propostas tornam-se irrelevantes. Os filósofos greco-romanos e os teólogos cristãos da Idade Média refletiram sobre a prática moral a partir de um ponto de vista interno à ela, a partir de uma perspectiva do sujeito que é o autor da prática e também o seu ator, mediante a mesma prática, propondo o que Abbà chamou de ética da primeira pessoa.

A partir do século XIV, prossegue o estudioso, afirmou-se outro tipo de leitura da prática moral, sob a perspectiva do jurista (questão que examinaremos mais adiante). E, depois de Hobbes e de Hume, deixou-se de compreender a experiência moral como prática, passando-se a entendê-la como fato a ser explicado conforme o modelo da nova ciência da natureza, do que resultou uma ética da terceira pessoa. Contudo, Abbà conclui que somente o ponto de vista da primeira pessoa é perfeitamente apropriado à prática moral, em função de sua própria essência e de sua inerente dramaticidade.

Para encerrar a exposição de Abbà sobre a experiência e a filosofia moral - que terá grande utilidade não só para nós, mas também para o leitor avaliar a ética de Rosmini - é preciso acrescentar que o conhecimento chamado prático não é intuitivo, mas discursivo, pois conecta princípios e conclusões, sendo que os primeiros consistem nos bens desejados e reconhecidos como tal e as últimas são as ações ou omissões do agente, em razão de sua escolha. Além disso, o conhecimento prático que exercitamos como autores e atores em nossa conduta pessoal é passível de desenvolvimento e esclarecimento, seja pela consciência pessoal, seja pela representação narrativa ou teatral, ou ainda pela especulação filosófica.

Acrescenta o autor: 
"Esclarecidos os princípios noéticos do conhecimento prático, a filosofia pode proceder à crítica e à verificação das conclusões mais ou menos imediatamente práticas, de modo a comprovar sua coerência com os princípios e, conforme o resultado do exame, refutá-las, corrigi-las ou recebê-las como bem fundamentadas, ou ainda propor-lhes alternativas. Por este caminho, a filosofia moral contribui com a crítica e com o melhoramento da racionalidade prática imanente ao ethos social e à consciência pessoal moral”. (Abbà, 2011, p. 44)

Por fim, essa situação da filosofia moral em relação à prática moral, tal como se revela em nossa própria experiência moral, é decisiva para o sucesso e a validade da reflexão filosófica. Se a filosofia moral desvela a racionalidade imanente, a experiência moral, por sua vez, é normativa para a verdade da filosofia moral: uma filosofia moral é verdadeira, válida, bem-sucedida na medida em que consegue dar razão de todos os aspectos da experiência moral, sem descuidar ou deformar qualquer um deles. De resto:

"Não existe filosofia moral perene a ser exposta e defendida. Existem diversas figuras históricas e diversas tradições de filosofia moral: não é possível esquivar-se das configurações históricas para julgá-las a partir de um ponto de vista superior, neutro, com base em razões compartilhadas por todos. A pretensão de lograr isso, típica do Iluminismo, naufragou numa multiplicidade de teorias incompatíveis entre si: a razão iluminista demonstrou não ser a razão de todos os homens, mas a razão do homem ocidental moderno, hoje em dia cada vez mais submetida à crítica pelas igualmente multicolores correntes do pensamento pós-moderno" (Abbà, 2011, p. 57).

\subsection{Ethos social e debate ético contemporâneo}

É difícil discordar da avaliação de que:

"O ethos das sociedades ocidentais hoje é um conjunto heterogêneo de resíduos de variada procedência: da moral 
judaico-cristã, das morais secularizadas de orientação kantiana e utilitarista, da crítica às ideologias e à moral, da psicologia humanista da autorrealização, da psicanálise freudiana, da filosofia dos valores". (Abbà, 2011, p. 31)

Isso para não falar de sistemas religioso-morais orientalizantes e esotéricos. Simultaneamente, esse juízo do estudioso italiano citado, com o qual concordamos totalmente, se coaduna à perfeição com a constatação de Rodrigues Alves (2015) de que "vivemos uma grave crise moral, determinada por um desproporcionado subjetivismo e relativismo" (p. 27), que convive com uma variedade de sistemas éticos como jamais houve na história da filosofia. Prossegue R. Alves e com ele anuímos:

"Os discursos éticos proliferam, em velocidade proporcional à crise ética. Nesse contexto cultural, observa-se a necessidade de afirmar regras de convivência social, sem querer fundá-las em algo de último. As regras e as leis morais se multiplicam cada vez mais e se tem a sensação de que elas carecem de um valor determinante" (R. Alves, 2015, p. 27).

Isso o leva esse autor a perguntar - por sinal, notamos, como Rosmini:

"Se realmente é possível uma ética sem metafísica, ou seja, sem a afirmação do valor ontológico do conhecimento humano. Se a inteligência humana é incapaz de conhecer o ser real, tal qual é na realidade, pode formular preceitos que respeitem a realidade mesma?" (R. Alves, 2015, p. 27)

Estamos totalmente de acordo com a resposta de R. Alves, que formularemos a seguir, com excertos de seu livro, conquanto apresentados em ordem diversa à seguida pelo autor, mas que explicita a interpretação que dela fazemos:

"Exatamente porque boa parte da cultura contemporânea considera que não haja um vínculo essencial entre verdade, bem e liberdade, torna-se primordial a possibilidade de tais ligames. Pode-se aceitar pacificamente o ceticismo e o niilismo de boa parte de nossa cultura? Parecenos que não. De fato, são muitos os estudiosos que atualmente dirigem sua atenção a autores clássicos - Platão, Aristóteles, Agostinho, Tomás de Aquino -, procurando, senão as soluções, 
ao menos as sugestões para um crescimento mais humano na nossa cultura" (R. Alves, 2015, p. 18).

R. Alves lembra ainda que:

"o retorno ao estudo desses autores deve-se à influência de importantes filósofos do século passado, tais como F. Brentano, E. Husserl, M. Heidegger, J. Gadamer”, acrescentando que "posteriormente, vários participantes dos cursos sobre a filosofia aristotélica, ministrados por Heidegger, nos anos 20, deram origem na Alemanha à chamada 'reabilitação da filosofia prática" e enfatizando ser "bem conhecido que Heidegger denunciou o esquecimento do ser na filosofia e constatou a íntima relação do ser com a verdade e a liberdade. De fato, " esquecimento do ser tende a causar o esquecimento da verdade, assim como negar que o ser enquanto tal é bom" (R. Alves, 2015, p. 19).

Nada melhor para dar concretude a essas reflexões desse pesquisador do que o exemplo por ele mesmo apresentado duas páginas antes:

"Não seria exagerado afirmar que a atual crise financeira surgiu, no fundo, de uma crise ética. De fato, empresas que pareciam possuir grandes recursos e importantes lucros anuais, de repente, declararam falência. Atualmente, vem sendo comprovadas que as descrições contábeis apresentadas eram falsas, algo que influenciava todo o mercado. Esse fato pode ser lido como uma falta de compromisso com a verdade, algo que causa uma das mais graves crises da época contemporânea e deveria levar-nos a pensar que a verdade não é mera construção humana e a ética é mais do que um assunto privado e opcional para a vida social e profissional. Não há nenhuma 'mão invisível' que regule o mercado. Fazê-lo é tarefa humana que implica uma ética orientada por valores concretos, tais como a competência profissional, a transparência, a honestidade e a responsabilidade. Em outras palavras, é necessário um 
renovado compromisso com a verdade e a justiça". (R. Alves, 2015, p. 19)

Levando em consideração tudo o que apresentado até aqui sobre o debate ético contemporâneo, não há mais necessidade de retardar a exposição dos principais aspectos da doutrina moral de Antonio Rosmini e responder definitivamente a questão sobre sua atualidade. Empreenderemos, pois, a seguir, uma síntese dos Princípios, que, embora seja a obra mais breve, é o documento mais completo e especulativamente mais vigoroso das doutrinas morais de Rosmini, segundo o consenso dos estudiosos de sua obra.

\subsection{Princípios da ciência moral}

Para o roveretano, a "Lei moral" é uma "noção da mente" usada para julgar a moralidade das ações humanas e de acordo a qual se deve agir. Para que isso ocorra, concorrem três condições: 1) que a noção seja recebida na mente do sujeito humano; 2) que este sujeito reconheça sua aptidão para ser usada em juízos morais, ou, nas palavras de Rosmini, que ele a "promulgue"; 3) que essa noção finalmente seja aplicada nas ações da vida prática. Ao dizer que a lei é uma "noção", o autor pretende reduzir a definição da lei à sua maior simplicidade filosófica, explicando que, se nos defrontamos com a regra "não fazer mal ao meu semelhante", ela faz sentido desde que tenhamos a noção de "mal". Do contrário, seríamos, como um cego de nascença, incapazes de ter a noção de cor.

A seguir, Rosmini reflete que muitas noções dependem de outras e que em uma série de noções, em que cada uma das quais depende da noção anterior e a pressuponha, deve haver um fim, pois, do contrário, prosseguiríamos ad infinitum (conforme o ensinamento de Aristóteles, na Metafísica $\alpha 2$ ). Esse raciocínio se estende às noções morais, das quais a primeira lei é justamente a primeira noção com que se formam os princípios morais. Ora, esta primeira noção da mente, conforme demonstrado pelo autor no Nuovo saggio, é a ideia do ser, que é congênita no espírito humano, inata, e que é a forma (no sentido aristotélico da palavra) da sua inteligência e a que Rosmini chama de "lume da razão", a qual deve iluminar a razão humana para guiá-la, pois a razão, precisamente por ser humana, está sujeita ao erro. 
Daí decorre a primeira máxima moral rosminiana: "Segue, no teu agir, o lume da razão". Mas, além disso, o filósofo faz questão de deixar claro que, embora ligados intimamente, não se confundem nem são um só o homem-sujeito e a ideia do ser, que é objeto. Essa distinção, sobre a qual Rosmini insiste, leva-o a criticar a moral de Kant, pelo fato de o filósofo de Könisberg atribuir a perfeição do objeto ao sujeito e, assim, divinizar este último, considerando-o o autor da lei e conferindo-lhe a autonomia. Já a moral do sensismo empírico atribui ao objeto, isto é, à ideia do ser, a imperfeição do sujeito, anulando-lhe a possibilidade de legislar por si só e estabelecendo a heteronomia. Por outro lado, deixando de lado as críticas, Rosmini se indaga como saber que a ideia de ser é a suprema lei moral.

Em busca da resposta, considera necessário, em primeiro lugar, investigar o que é o bem e o faz partindo de uma definição do senso comum: os homens costumam chamar de bem aquilo que lhes apetece. Mas, por um lado, não se trata só de determinar quais são as coisas que apetecem, mas de reconhecer que, primeiro, é necessária a existência de um ser capaz de ser apetecido. Considerando a existência desse ser, tornase evidente que, antes de mais nada, ele deve apetecer-se de si mesmo, da própria existência e da própria conservação, e, depois, de tudo aquilo que pode torná-lo mais perfeito e completo. Desse modo, existe uma "faculdade de apetecer", conceito que compreende a tendência a deleitar-se de si, a amar a si mesmo e a todos os bens e perfeições da natureza.

Caso o homem não tivesse essa faculdade de apetecer, que lhe vem do sentido, não lhe seria possível formar a ideia de bem e das perfeições de nenhuma natureza. $O$ próprio Rosmini afirma:

"Por exemplo, a perfeição de uma flor ou de um fruto está na própria flor e no fruto, mas sou $\mathbf{E u}$, ser diverso deles, que os apeteço, sinto-lhes o odor ou o sabor; sou eu quem forma a ideia daquele fruto ou flor, da sua natureza, das suas perfeições, daquilo que convém ou não à natureza deles. Ora, digo que a relação que aquele fruto e aquela flor têm comigo e em geral com os seres que podem receber sensações a partir deles é tão essencial, que a existência daqueles seres pressupõe essa relação; nem se pode imaginar essa relação anulada, sem jogar fora e anular esses mesmos seres e até mesmo a sua própria possibilidade". (Ver p. 86 de nossa tradução.) 
Surge daí uma nova indagação: pode existir um bem sem que seja sensível e apetecível? Por um lado, o roveretano diz que não, pois a matéria insensível só é chamada de bem ao ser sentida e conhecida pelo ser sensível; por outro lado, sim, pois se o conceito de bem depende do sentimento é o bem real que desperta o sentimento. Ao lado disso, os seres em geral se apresentam à sensibilidade e à inteligência humana com uma "ordem intrínseca" e nessa ordem a inteligência divisa o bem. Ou seja:

1) Entes reais podem ser encontrados em diversos estados.

2) Um desses estados é escolhido por nosso entendimento como perfeito.

3) Nesse estado-tipo há uma ordem em que o intelecto vê o bem.

4) Essa ordem, que começa com a existência e a essência do ente, vai se complementando com outros graus de entidade.

Decorre disso tudo que bem, perfeição e "ser" se equivalem, o que explica porque a sensibilidade se liga ao bem: porque ela pertence ao ser. Enfim, Rosmini afirma que o bem é o ser completo ou em aperfeiçoamento, considerado na ordem em que é conhecido pela inteligência que dela se deleita. Portanto, o conhecimento do ser de uma coisa é o conhecimento de sua bondade: eis como a ideia de ser permite julgar o bem.

Concluída, assim, a demonstração de que a noção de "ser" é o primeiro princípio da moral, Rosmini passa a estabelecer outros princípios que dele decorrem. Começa por distinguir o "bem subjetivo", ou humano, que é o bem considerado em relação ao sujeito que o goza, e que, portanto, é um bem relativo, do "bem em si", que não pode ser considerado relativamente a ninguém, pois as coisas podem ser boas exclusivamente enquanto são e tendem com todas as forças de sua natureza à própria conservação e perfeição. Ora, o "bem em si" é o objeto da moral, enquanto o "bem subjetivo" é o princípio de uma outra ciência, a eudemonologia ou ciência da felicidade. Vale notar que aqui a perspectiva de Rosmini se aproxima da de Kant: ambos consideram a moral como a ciência do dever. Ao mesmo tempo, ambas as perspectivas se afastam, pois Kant nem fala numa eudemonologia, mas num eudemonismo, que, segundo ele, é o ponto de vista do egoísmo moral, "de quem restringe todos os fins a si mesmo e nada vê de útil fora do que lhe interessa" (Kant, 2011, I, § 2).

Mas a reflexão de Rosmini sobre o bem não se encerra nisso: ele distingue outras duas categorias de bem: assim como o ser é substancial ou acidental; do mesmo modo o bem pode ser de existência ou de perfeição. Para o homem, o primeiro bem é a própria existência; já os bens de perfeição podem ser relativos ao corpo, ou ao intelecto, 
sendo este superior, pois permite ao homem perceber todas as espécies de bem, até se aproximar do Bem absoluto, o bem em seu sumo e último grau: Deus. Nessa ascensão consiste a felicidade máxima ou beatitude, também superior aos prazeres limitados e momentâneos. O intelecto humano não tem necessidade de parar seus desejos até chegar ao sumo bem e é nessa potência que repousa a excelência extrema da criatura humana. Contudo, Rosmini considera que entre os bens corpóreos e espirituais não há contradição, mas hierarquia, pois todos os bens de um sujeito inteligente são objetos pertencentes à inteligência. De resto, o homem é um sujeito único: quem atenta contra seu corpo, atenta contra sua personalidade, que tem a dignidade do ser intelectivo.

O deleite desse ser inteligente é o conhecimento: contemplação imparcial e plena que faz justiça ao objeto contemplado e presta homenagem à verdade. O bem absoluto só pode ser intuído ou concebido por um ato da inteligência. Trata-se, portanto, de um bem objetivo e decorre de um ato de razão, onde se encontra o princípio da justiça. Desse modo, o ato moralmente bom tem por termo o bem objetivo e se dá por amor ao bem divisado nos seres em si. Se a forma da inteligência é a noção do ser universal, igualmente a forma da moral é o amor universal. Em outras palavras, a primeira máxima moral, "segue o lume da razão", pode ser transformada em uma nova máxima: "ama todos os seres".

O bem objetivo, no entanto, não é propriamente o bem moral. Ele se torna moral apenas quando querido pela vontade, ou seja, quando o sujeito quer o bem objetivo que a mente conheceu. Assim, Rosmini concebe a vontade como a potência com a qual o sujeito inteligente atua, ela é a potência ativa da inteligência humana, que torna o homem autor de suas ações. Segundo o roveretano, sem a vontade o sujeito não passa de "um cenário em que atores estrangeiros representam um drama qualquer, no qual ele toma parte como simples espectador". Por conseguinte, para ser moralmente bom, o homem tem de ser o autor do bem moral que lhe é atribuído.

Há, para Rosmini e para a metafísica clássica de um modo geral, uma hierarquia dos seres e dos bens, segundo a qual o ser sensível e inteligente é superior aos insensíveis. Desse modo, os seres materiais e irracionais constituem coisas ou meios, ao passo que os seres inteligentes constituem pessoas e fins, sendo justamente em sua razão de fim que se encontra seu caráter e sua dignidade pessoal (aqui, mais uma vez se aproximam o pensamento de Rosmini e de Kant). É essa a ordem intrínseca do ser que o homem vê com a sua inteligência e, quando a vontade ama o ser nessa ordem e quer o bem, esse mesmo homem se torna moral. Com isso, aperfeiçoa-se a máxima 
moral tal qual até agora apresentada: "Ama o ser onde o conheceres, na ordem em que se apresenta à tua inteligência".

A partir desse ponto, o roveretano desenvolve o que se poderia chamar de psicologia da moral, pois passará a investigar como ela se processa no interior da mente humana. Para começar, distingue no homem duas faculdades passivas: 1) o sentido, que percebe as coisas subsistentes e é subjetivo; 2) a inteligência, que conhece as coisas possíveis e é objetiva. Em contrapartida, aponta duas faculdades ativas: 1) o instinto, que segue o prazer e opera sobre o sujeito inteligente; 2) a vontade, que mostra o dever e torna o homem autor de suas ações. A vontade é uma potência ativa, que opera segundo as razões da mente, pois o conhecimento precede a vontade. $\mathrm{O}$ conhecimento, por sua vez, se subdivide em três tipos: a) um instintivo ou direto, trazido pelos sentidos; b) um reflexivo, que avalia o conhecimento anterior; c) e um volitivo, que ocorre quando a vontade assente à avaliação anteriormente feita e impulsiona à ação.

Desse modo, a ação voluntária é a expressão de um efeito de amor, de um amor prático, que dura o instante que precede a ação e a determina. Mas o amor é o afeto de um ser inteligente que se dirige a um objeto conhecido, objeto que mostra à mente seus méritos e a faz admirá-los e amá-los. Portanto, o amor não é um instinto, pois em sua natureza contém uma estimativa prática, que realiza o julgamento dos méritos e qualidades do ente desejado e nessa estimativa reside a liberdade da vontade. Para aprofundar a compreensão do processo, Rosmini explica que o conhecimento direto perceber as coisas como elas são, passivamente - é um conhecimento necessário, mas não voluntário.

Este conhecimento é seguido por um conhecimento reflexivo ou reconhecimento, este sim um ato voluntário do espírito, sujeito à minha vontade, acompanhado pelo amor que desencadeia a ação. Como a vontade move a reflexão ou reconhecimento das coisas conhecidas diretamente, ela é boa se reconhece imparcialmente o mérito das coisas, se se move pela verdade e pela bondade. Ao contrário, se os desconhece, se vê os méritos ou defeitos de um modo mais forte do que conviria, ela pode gerar defeitos ou qualidades que não existem e gerar um amor ou um ódio irracional. A vontade má tem duas medidas: uma com que julga as coisas que lhe são favoráveis, outra com que julga as que lhe são desfavoráveis.

Em outras palavras, quando o conhecimento direto e o reconhecimento estão em acordo, manifestam-se a veracidade e a justiça, que trazem quietude interior e paz. Quando estão em desacordo, manifestam-se a mentira e a injustiça, de que decorrem 
um conflito interior. Se o ser é a verdade primeira e universal, que se conhece diretamente, o reconhecimento do ser, de acordo com o conhecimento direto, mostra a verdade, que é, assim, também um dos princípios da moral.

Ainda no âmbito da psicologia da moral, Rosmini define alguns conceitos:

a) Intelecto moral: aquele que considera o uso do ser como lei moral.

b) Razão moral: potência de aplicar o ser enquanto lei moral, deduzindo as leis menores da lei primeira e universal e definindo as ações justas e injustas.

c) Razão eudemonológica, que aplica o ser para julgar o bem subjetivo.

d) Razão prática: eficácia da razão voluntária para formar a estimativa, considerando e dando predominância, seja as razões eudemonológicas ou morais.

e) Consciência moral: juízo que faço de mim, de caráter especulativo sobre a moralidade de meu juízo prático e suas consequências.

Por fim, esclarecendo que não pretendeu redigir um tratado sobre Ética, mas expor alguns de seus princípios, Rosmini faz algumas reflexões de caráter normativo. Primeiramente, deixa claro que o ato moral é produto da lei e da vontade que se conforma à lei. Quanto maior for a lei e a eficácia da vontade - que se mede pelos graus de intensão e liberdade - em assentir à lei ou em negá-la, tanto maior é o louvor ou a censura que o agente merece. Igualmente, no que se refere à má ação, ela também resulta da conjugação entre a lei violada e a livre vontade que a viola.

Entre os deveres do homem, Rosmini destaca a gratidão, que nasce do reconhecimento de termos recebido um bem com a nossa existência. Logo, amamos a nós mesmos, pois somos um bem para nós e, por conseguinte, devemos sentir gratidão com relação ao nosso Criador, que nos deu a nós mesmos como bem. Aquele em quem o amor-próprio não reconhece o bem recebido incorre em injustiça e torpeza moral. Quanto aos nossos semelhantes, temos o dever de amá-los, mas isso não lhes dá direito sobre nosso amor. Os direitos do homem correspondem, ao contrário, aos deveres negativos. Por exemplo, temos o dever de não fazer mal aos nossos semelhantes e, igualmente, eles têm o direito de que nós não lhes façamos mal.

O direito é propriedade de cada um e ter direito significa poder se armar para se defender de quem tentar feri-lo. De resto, não é o direito do homem que produz o dever, mas a lei. Além disso, os deveres aos quais correspondem direitos têm a ver com a justiça, já os deveres aos quais não correspondem direitos têm a ver com o amor e a caridade. Por fim, o ato moral não se refere ao Eu, mas à verdade. Então, é o caso de perguntar: temos deveres para conosco mesmos? Como sujeitos não, mas como objetos, 
devemos a nós mesmos tudo que devemos a outro ser humano, à natureza humana. Mas como conhecemos o bem da natureza humana?

São as nossas próprias experiências que nos levam a conhecer nossos semelhantes, as experiências sentidas pelo sujeito/Eu. A partir daí Rosmini conclui com uma interessante interpretação do mandamento "amar o próximo como a ti mesmo". Para ele, o "como a ti mesmo" é um exemplo de como devemos amar. Quanto ao “próximo", palavra que considera "admirável”, ele lembra que, por um lado, o próximo também sou eu de mim; e por outro, que de qualquer maneira o Eu será o ponto a partir do qual se medir a proximidade ou a distância. "É, portanto, perfeita e totalmente divina a enunciação da lei 'amarás ao próximo como a ti mesmo'; e os deveres para conosco estão compreendidos nessa enunciação, e alocados no lugar que melhor lhes convêm”.

\subsection{A atualidade da ética rosminiana}

Façamos agora uma rápida avaliação do sistema moral de Antonio Rosmini, seguindo as reflexões sobre Ética de Abbà e de R. Alves, que previamente apresentamos. Para começar, é preciso notar que, embora o roveretano inicie a sua pesquisa sobre os princípios da Moral, refletindo sobre noções como "lei”, "ser", “bem”, tipos de bem, ele passará, no capítulo V, a proceder a análise da vontade e, mais especificamente a partir do artigo III deste capítulo, a esboçar uma psicologia da moral, isto é, a considerar o homem como agente moral. Nesse sentido, sua doutrina se torna uma ética de primeira pessoa, aquela que, como vimos, captura de fato a razão de ser de uma doutrina ética. Aliás, Rosmini aprofundará essa perspectiva de maneira admirável, ao analisar o mandamento bíblico "amarás ao próximo como a ti mesmo", tanto por entender que ninguém é mais próximo de mim do que mim mesmo; quanto quando afirma que o eu é o ponto a partir do qual se mede a proximidade e a distância.

Em segundo lugar, seguindo ainda o raciocínio de Abbà, mesmo que a doutrina moral de Rosmini tenha como base a fé cristã, isso não o impede de expor suas ideias com um discurso eminentemente racional, lógico e dedutivo. Por um lado, isso ocorre à medida em que a noção de ser que o autor considera o "lume da razão", embora tenha para ele origem divina, não se confunde com Deus. O ser a que Rosmini se refere na maior parte de seu livro é o ser em geral e não o Ser supremo, do qual aquele deriva para os que creem, mas que, para os que não creem, como Heidegger, existe assim 
mesmo, ou melhor: é. O ser é o não ser não é. A propósito, o roveretano vai considerar o reconhecimento do ser como uma expressão do próprio princípio de identidade, um fundamento da Lógica.

Ainda sob o ponto de vista do discurso filosófico, o texto de Rosmini tem caráter dialético ou dialógico, pois confronta as filosofias de sua época, contra-argumentando aos sistemas morais de Locke, Condillac e Kant, entre outros. Desse modo, o roveretano cumpre as duas funções que ele mesmo atribui à filosofia: 1) combater o erro e 2) sistematizar a verdade. Aliás, vale a pena ressaltar, a essa altura, que os Princípios de ciência moral são também uma demonstração do princípio geral enunciado no Nuovo saggio sulle'origine delle idee, segundo o qual o entendimento humano depende de uma única ideia inata ou a priori: a ideia do ser. Sem ela, nada é inteligível. Não podemos pensar o que não é. Por conseguinte, é pela ideia geral do ser e por suas determinações possíveis, trazidas pelos sentidos, que se podem explicar todos os princípios e ramificações do pensamento. Nos Princípios de ciência moral, Rosmini demonstra como essa ideia do ser pode servir de regra para julgar as ações morais, a partir das diversas determinações que ele atribui ao ser em geral, convertendo-o em bem e verdade.

Ora, essa conversão é justamente o cerne do debate ético proposto por R. Alves que evidencia a renúncia à capacidade de o homem compreender o ser real como princípio da crise ética do mundo contemporâneo. Se não podemos conhecer o ser, não podemos conhecer a verdade e conceitos como o de bem e mal tornam-se relativos. Rosmini segue na direção oposta disso, afirma o ser como "lume da razão" e "forma da inteligência" que possibilita o conhecimento ao homem. Em suas próprias palavras:

"Ser e bem são, portanto, o mesmo, apenas que o bem é o ser considerado na sua ordem, a qual é conhecida pela inteligência, que conhecendo-a, dela se deleita: o bem, em uma palavra 'é o ser sentido em relação com a inteligência', enquanto essa vê aquilo que toda natureza exige de si mesma, aquilo que tende com suas forças do modo já mencionado".

Além disso, prossegue o roveretano:

"Diz-se verdade a um exemplar, tipo, norma ou regra da mente, à qual se comparar e verificar o que lhe deve ser conforme. Esse tipo é a verdade das coisas que a ele se referem: uma coisa é verdadeira se conforme a sua verdade, se é 
conforme àquele seu tipo. Do contrário, é falsa. O ser é o exemplar primeiro e universal, a regra suprema de todos os juízos. É, portanto, a verdade primeira e universal".

Essas palavras de Rosmini ecoam as palavras de Agostinho de Hipona: “o verdadeiro é aquilo que é" (Solilóquios, II, 5); e de Tomás de Aquino: “o verdadeiro é totalmente idêntico ao ente" (Sobre a verdade, Q. I, art. 1). Em outras palavras, colocando-se as questões postas pelos filósofos do século XVII e XVIII, Rosmini procura respondê-las retornando pioneiramente aos clássicos, como fariam posteriormente Brentano, Husserl, Heidegger e Gadamer.

Sem querer nos alongarmos demais nos aspectos filosóficos, para levantar as questões atinentes à tradução, não podemos deixar de acrescentar, para comprovar a atualidade do pensamento do filósofo de Rovereto, uma comparação entre um trecho dos Princípios da ciência moral e outro de $O$ ser e o nada, de Jean-Paul Sartre, filósofo cujo pensamento chega a ser, em seu conjunto, antitético ao de Rosmini. Por outro lado, podem-se encontrar proximidades entre os dois. Refiro-me aqui, especificamente, ao capítulo II da Primeira parte do clássico sartreano em que o autor trata daquilo que define como "má-fé" e que integra a sua chamada analítica existencial. Basta transcrevermos este breve trecho do existencialista contemporâneo:

"Por certo, para quem pratica a má-fé, trata-se de mascarar uma verdade desagradável ou de apresentar como verdade um erro agradável. A má-fé tem na aparência, portanto, a estrutura da mentira. Só que - e isso muda tudo - na má-fé eu escondo a verdade de mim mesmo. Assim, não existe nesse caso a dualidade do enganador e do enganado. A má-fé implica por essência, ao contrário, a unidade de uma consciência" (Sartre, 1999, p. 94).

Comparemos, pois, esta definição sartreana, daquela que nos dá Rosmini de um fato psicológico idêntico, nos Princípios, cap. V, art. III - De que maneira as ações e os afetos dependem da vontade:

"Falo daqueles juízos com os quais primeiramente o homem busca a enganarse a si mesmo, falo daquela facilidade de dar crédito a rumores vagos, favoráveis às próprias esperanças e às próprias opiniões; daquela extrema dificuldade de dar crédito a notícias contrárias, ainda que bem fundamentadas; daquele exagero perpétuo, do qual um evento desejado é sempre estimado muito maior que o verdadeiro e um 
acontecimento desagradável se atenua e apequena; daquela atenta vigilância em certas coisas e daquele esquecimento de certas outras; daquela agudeza, que de um fato recolhe, releva e predica todas as minuciosas circunstâncias que agradam e imagina também aquelas que possam ser de algum modo verossímil; e daquela obtusidade voluntária em que se ignoram, negligenciam e se deixam de lado todas aquelas que desagradam" (p. 167).

Consideramos desnecessário tecer qualquer comentário, pois as semelhanças são evidentes. Sartre fala em "mascarar uma verdade desagradável ou de apresentar como verdade um erro agradável" e na inexistência de "dualidade do enganador e do enganado". Rosmini, dos "juízos com os quais primeiramente o homem busca a enganar-se a si mesmo", dando facilmente crédito "a rumores vagos, favoráveis às próprias esperanças e às próprias opiniões" e, contrariamente, daquela "extrema dificuldade de dar crédito a notícias contrárias". Evidentemente, trata-se do fato de ambos os filósofos terem concebido uma mesma situação existencial, ainda que partindo de pressupostos diversos e numa época bastante diversa. De resto, as convergências entre os dois se encerram nesses pequenos trechos, prosseguindo a investigação de ambos uma direção diferente, que não vem ao caso para a nossa tese.

Para encerrar, apresentemos ainda outra comparação, desta vez relacionada ao dever da gratidão pela vida, de que o roveretano trata no cap. VII, art. V - Da gratidão. Rosmini, evidentemente, considera um dever do homem dar graças a Deus pela existência, o que procura comprovar com o seguinte raciocínio:

“A gratidão é um sentimento misto de mais afetos, que não é tão fácil de analisar; todavia arrisco-me a dizer o suficiente para saber como esses afetos constituem a matéria de um dever moral.

"Eu me amo a mim mesmo, sou um bem para mim mesmo: nada nisso ainda é moral: este é um instinto, um bem subjetivo. Todavia, sei que existo não por mim mesmo, mas pela vontade de um outro ser que me deu a existência. $\mathrm{O}$ amor que tenho para comigo mesmo, para com a minha existência, se estende naturalmente para a causa que me produziu e a considero como boa para mim, porque origem do meu bem, então amo também a ela, porque toda coisa que se estima boa se ama.

“Esse sentimento natural é conforme a verdade, pois é verdadeiro que eu seja um bem para mim mesmo e que a causa que me produziu seja boa relativamente a mim; portanto devo 
julgá-la e estimá-la assim, porque a concebo e ela é tal efetivamente" (p. 196).

Compare-se o trecho acima com a passagem do livro "Espiritualidade para céticos”, do agnóstico Robert C. Solomon (1942-2007), professor de filosofia por 30 anos na Universidade do Texas em Austin. A obra foi originalmente publicada em 2002 e a primeira edição brasileira data de dois anos depois. Afirma Solomon:

"Que significa sentir gratidão, não por esse ou aquele favor particular prestado por outras pessoas ou mesmo (como no caso de nossos pais ou de um excelente professor) por terem elas traçado o curso de toda a nossa vida, mas (em certo sentido) à própria vida, ao universo como um todo? $\mathrm{Na}$ medida em que personificamos o fado, por exemplo na personalidade de Deus ou de algum anjo da guarda, há uma interpretação direta da gratidão. Somos gratos ao nosso Deus ou ao nosso anjo da guarda por que ele (ou ela) fez alguma coisa pela qual a gratidão é apropriada. Parece-me, porém, que nós, naturalistas, renunciamos a muita coisa ao relegar a gratidão ao monturo sobrenatural só porque não há nenhuma pessoa particular a quem sentir-se grato. Isso não significa que não há necessidade de gratidão.

"Essa concepção naturalista da gratidão ou do reconhecimento é uma extensão de nossa emoção mais usual, interpessoal. Nesse caso, é a emoção e não a especificidade de seu objeto que determinam em última instância seu sentido. Quer haja quer não suficiente personificação do fado para justificar agradecimentos pessoais, o reconhecimento do fado em qualquer sentido implica que somos beneficiários de um universo (mais ou menos) benigno. Isso deveria impor gratidão, ainda que ela não tenha por objeto ninguém ou nada em particular" (Solomon, 2004, p. 221).

Está claro que ambos os pensadores concordam na importância ou no dever da gratidão, muito embora deem razões opostas para justificar essa (im)posição. De qualquer modo, a comparação do roveretano do século XIX com um texano 
recentemente falecido serve não só para demonstrar a atualidade do pensamento de Rosmini, como para comprovar o valor das pesquisas éticas:

"Que ousam transgredir as fronteiras que separam a filosofia moral laica da ética cristã, e as transgridem em benefício de ambas as partes, uma vez que cada uma delas tem algo a aprender com a outra. Em geral, falta aos teólogos moralistas o compromisso argumentativo, que é obrigatório entre os filósofos laicos; no entanto, estes quase sempre ignoram ou entendem mal as posições do pensamento moral cristão" (Abbà, 2011, p. 14).

Feitas essas considerações, voltaremos a tratar de alguns pontos filosóficos do pensamento ético rosminiano, de acordo com um de seus mais dedicados intérpretes, o historiador da filosofia Michelle Federico Sciacca.

\subsection{Coda filosófico-literária}

Coda é uma palavra existente tanto em italiano quanto em português e significa, figurativamente, um acréscimo que se faz à parte principal de uma obra musical ou literária. É nessa acepção exata que a empregamos como subtítulo para esta parte do trabalho, a qual visa apresentar três aspectos divisados por Sciacca na ética rosminiana, no capítulo final da monografia La filosofia morale di Antonio Rosmini, intitulado Interpretazione e valutazione critica. Trata-se, a nosso ver, de pontos importantíssimos para uma correta e completa interpretação do roveretano e a expomos ou traduzimos aqui, uma vez que não existe edição desse estudo para o português e também porque Sciacca, sendo filósofo e historiador da filosofia, leva a avaliação do pensamento do roveretano a alturas especulativas que, enquanto simples tradutor, não conseguiríamos levar.

\section{1) Moral: forma e conteúdo}

O primeiro aspecto a ser apontado refere-se ao formalismo da moral kantiana. Conforme Pegoraro (2006, p. 106):

"O imperativo categórico ou lei moral [para Kant] não tem conteúdo empírico; por isso é simplesmente uma forma. (...) A 
pura forma da lei moral consiste na sua universalidade que abrange todos os seres racionais. Seu principal enunciado é o seguinte: 'Age de tal modo que a máxima de tua vontade seja sempre válida, ao mesmo tempo, como princípio de uma legislação universal' (Kant, 2011). Em outras palavras, a máxima é sempre subjetiva, pois é uma norma que o indivíduo escolhe para si mesmo; por outro lado, de modo a se tornar lei moral ela deve poder ser universalizável, válida para todos os seres racionais. Assim, como diz o próprio Kant: 'Se um ser racional deve pensar suas máximas como se fossem leis práticas universais, só pode pensá-las como princípios tais que contêm o motivo determinante da vontade não segundo a matéria, mas unicamente segundo a forma' (Kant, 2011)".

Mesmo reconhecendo que a lei moral se reduz a uma ideia e, por conseguinte a uma forma, a análise que Rosmini faz do princípio formal segue caminho diferente do kantiano e é "um ponto da moral rosminiana unanimemente reconhecido como o mais original e como aquele que assinala um progresso mesmo em referência ao próprio Kant (Sciacca, 1955, p. 207). Para Rosmini, segundo Sciacca:

"Um princípio formal, isto é, que exprima exclusivamente a força da obrigação, sem indicar os objetos a que se endereça a obrigação, é um princípio abstrato e se deve somente a uma apreensão incompleta e insuficiente do princípio da moral. Antes de discutir se o princípio da moral é formal ou não e de admitir, sem mais, que ele o é, torna-se preciso definir como deve ser tal princípio e indagar se é possível um princípio puramente formal, 'dada a relação essencial entre a força de obrigar e seus objetos'. E, precisamente, não é possível uma força de obrigação sem qualquer relação com os objetos e, portanto, o princípio formal por definição indica tal relação. Se é assim, ele, embora conservando sua formalidade, perde o caráter de formalidade abstrata e adquire um conteúdo (...) Desse modo fica salva a formalidade e ao mesmo tempo é superado o formalismo" (id. p. 208). 
Para Rosmini, a lei somente não basta para explicar a moralidade; é uma condição necessária, mas não suficiente; falta-lhe ser determinada pela experiência, a qual faz nascer em nós a noção de bem. Enquanto esse bem é considerado em relação ao sujeito que dele usufrui, ele é um bem subjetivo, mas necessário para que dele se extraia a noção de bem objetivo, quando ele já não é mais somente sentido, mas também conhecido, pois o bem objetivo é um bem desinteressado: o sujeito o contempla sem referi-lo a si mesmo. Mas o bem objetivo ainda não é o bem moral, para tornar-se este é necessário que seja querido (ou amado) pela vontade, pois o bem moral "é o bem objetivo conhecido pela inteligência e querido pela vontade" (Principi, cap. IV, art. 7). Disso decorre que o imperativo categórico rosminiano seja "ama o ser onde quer que o conheças, na ordem em que ele se apresenta à tua inteligência".

Nessa fórmula:

"A lei, de possibilidade, se torna, digamos assim, atualidade moral, na medida em que ao ser ou bem conhecido pela inteligência, dado que ele se insere o sentimento que lhe fornece a primeira noção de bem, une-se a vontade que, determinando-se segundo o que é conhecido pela inteligência, ama o bem onde quer que ele se encontre, isto é como bem objetivo ou desinteressado (...) Rosmini, portanto, introduz o momento particular do querer no momento universal e à forma dá aquele conteúdo que a torna completa. Pode-se distinguir, mas não dividir o sensitivo do racional. Como a percepção intelectiva é síntese entre forma e conteúdo, assim também a atividade moral é síntese de forma e de conteúdo. Em Rosmini está viva a exigência de unidade entre o sentido e o intelecto" (id. p. 208-9).

\section{2) Dualismo causalidade e liberdade}

Um segundo aspecto que aproxima e afasta o pensamento de Rosmini e Kant é apresentado por Sciacca nos seguintes termos: "Kant, de fato, havia feito uma distinção entre o reino da liberdade e o reino da necessidade causal; o primeiro é próprio do modo numênico, o segundo do fenomênico". Vamos nos estender sobre isso, acompanhando a leitura que Scrutton (2011, p. 92) faz da questão, pois ela é essencial para 
compreender o empreendimento rosminiano em sua tentativa de resolver a antinomia entre necessidade e liberdade. Segundo Kant:

"Toda mudança que ocorre na ordem da natureza tem uma causa: este é um 'princípio estabelecido da Analítica' e não permite nenhuma exceção (Crítica da razão pura). Se é assim, então todo evento na natureza está ligado a cadeias de inelutável necessidade. Ao mesmo tempo, penso ser eu mesmo quem dá origem às minhas ações, realizando-as espontaneamente, sem influência de nenhuma coerção externa. Se minha ação é parte da natureza, isso parece contradizer a visão de que toda evento na natureza está ligado a uma necessidade causal. Se minha ação não é parte da natureza, então ela sai do campo da conexão causal, e minha vontade não dá origem a nada no mundo natural".

Em outras palavras e sempre acompanhando Scrutton, "a própria perspectiva da razão, que vê o mundo concatenado em cadeias de necessidade, também vê esse mundo contendo a liberdade". Trata-se da $3^{\text {a }}$. antinomia apresentada na Crítica da razão pura, segundo a qual Kant assume como 1) Tese: que a causalidade segundo leis da natureza não é a única causalidade pela qual possam ser explicados os fenômenos do mundo. É necessário admitir, para a explicação destes, também uma causalidade da liberdade; 2) Antítese: não há nenhuma liberdade, mas tudo no mundo acontece unicamente segundo as leis da natureza. Evidentemente, a filosofia até hoje se debate com a questão, malgrado os materialistas ou fisicalistas sustentem que "tudo no mundo acontece unicamente segundo as leis da natureza", embora a ciência empírica ainda não seja capaz de nos fornecer evidências cabais desse determinismo físico.

De qualquer modo, conforme o entendimento de Scrutton,

"Kant considerou que devia haver uma solução para essa antinomia, visto que é legítimo o emprego da razão na esfera prática. De fato, é a razão prática que me diz o que eu sou. $\mathrm{O}$ avanço ilusório da razão pura para a autocontradição não deve proibir a razão prática, por meio da qual, portanto, a antinomia deve ser resolvida. A razão pura deixa, por assim dizer, 'um lugar vago' em sua explicação de mundo, onde deveria ficar o agente moral. (...) Esta nova 'lei da causalidade' é chamada de 
'liberdade transcendental' e define a condição do agente moral. A lei de causa e efeito opera somente no campo da natureza (o campo empírico). A liberdade, porém, não pertence à natureza, e sim, precisamente, àquele campo 'inteligível' ou transcendental ao qual não se aplicam categorias como a causalidade. Eu existo no mundo da natureza, como uma 'aparência' [fenômeno] entre outras. Mas eu também existo como uma 'coisa em si' [númeno], ligada não à causalidade; e sim às leis da razão prática. Não que eu seja duas coisas, mas uma coisa só, concebida sob dois aspectos diversos" (Scrutton, 2011, pp. 92-93).

Rosmini, ao contrário, nega a distinção entre o numênico e o fenomênico e procura dar uma outra interpretação para o relacionamento entre liberdade e causalidade. Nas palavras de Sciacca (op. cit. p. 213), para o roveretano:

"O ato da liberdade é um ato de escolha entre dois bens diversos e, por conseguinte, se não existissem os dois bens, não poderia existir o ato da vontade. A presença de dois bens é, portanto, a causa do ato livre da vontade, mas o modo do ato, isto é, o querer mais um do que outro bem, é próprio da vontade".

Sciacca, porém, mesmo reconhecendo que o raciocínio é sagaz, afirma que ele não resolve o problema:

"A causalidade não só permanece fora do ato voluntário, mas também da atividade moral. Os dois bens, cuja presença deveria ser a causa do livre determinar-se da vontade por um ou por outro, podem ser considerados verdadeiramente bens? Enquanto não são queridos, são duas coisas, dois entes reais como tantos outros; tornam-se bens somente na medida em que são queridos. Por conseguinte, a casualidade não se refere a bens, mas a coisas e como tal resta estranha à moral" (Sciacca, 1955, pp 213-4).

\section{3) Ética, poética e cosmologia}

$\mathrm{Na}$ interpretação que faz da ética rosminiana, tal qual formulada nos Princípios, Sciacca atinge um ponto que se revela ao mesmo tempo muito radical e altamente... poético. Essa aproximação entre filosofia e poesia nos parece muito justamente 
remontar à mais remota tradição italiana, mas, para tornar claro o que queremos dizer, preferimos primeiro verter para o português um trecho mais longo do ensaio do historiador da filosofia siciliano, para depois tecermos brevemente nossa consideração.

Entre as páginas 216 e 218 de sua Interpretação e avaliação crítica, Sciacca (1955) afirma que, para Rosmini:

"A eficácia da vontade é tanta que altera o conhecimento, quando é dominada por outros interesses que não a verdade. $\mathrm{O}$ ato moralmente bom consiste, portanto, em reconhecer aquilo que primeiramente conhecemos, isto é, na harmonia entre o conhecimento reflexivo e voluntário, e o conhecimento direto e necessário; a imoralidade, em seu desacordo. $\mathrm{O}$ ato da boa vontade é o assentimento ao conhecimento; o ato da má vontade contrasta com a verdade, embora esta permaneça sempre verdade. Daí o remorso da consciência, que sente a inconveniência de fazer o mal e, por outro lado, sente a conveniência de reconhecer aquilo que conhece. Tal conveniência é a obrigação moral primeira, porquanto nos faz sair das contradições em que nos colocamos por nós mesmos. Assim, resulta que o ato moral é a síntese do conhecimento das coisas e da vontade, que se torna uniforme à lei com um ato de reflexão voluntária.

"O ato do reconhecimento empenha toda a atividade prática do homem. Este é essencialmente livre, antes, assim é na medida em que recebeu o dom da liberdade. Esta terrível potência pode fazer do homem a suprema finalidade do criado, assim como pode torná-lo a mais infeliz de todas as criaturas.

"O impasse se supera e o homem adentra seu caminho, quando a vontade segue o lume da razão, isto é, quando reconhece segundo o que há no homem de divino. A vontade, livre por si mesma, não é um mal, mas como tudo o que constitui a espiritualidade humana, é um dos bens que o homem recebeu de Deus. É ela que torna o homem propriamente capaz de agir moralmente. No uso mesmo da liberdade reside toda a 
dignidade e nobreza do homem, mas também o perigo de sua perdição, da subversão da ordem.

"Tal perigo é superado quando a vontade se determina de acordo com a lei, isto é, quando reconhece o conhecido e a ele dá o seu assentimento. Querer moralmente, de fato, significa reconhecer a cada ente o seu grau de ser na sua ordem, isto é, reconhecer em cada ente aquilo que constitui sua perfeição. Há, pois, uma escala infinita de seres, cada qual com sua ordem própria e que, no conjunto, constitui aquela realidade que é o criado, aquela ordem que é a ordem do universo. $\mathrm{O}$ ato moralmente bom é, portanto, aquele que faz seu a ordem universal. $\mathrm{O}$ homem, agindo moralmente, se torna quase partícipe daquele imenso bem que é o universo, fazendo-o seu e amando-o, quase recriando-o e vivendo-o como seu bem próprio. Agir moralmente significa ser em harmonia com a ordem cósmica. Desde que queira, o homem pode compreender espiritualmente na própria consciência todo o universo e dar-se conta da sua finalidade, que é, pois, a finalidade da existência humana".

Se atentarmos para o fato de que a "vontade" mencionada nesse excerto é uma vontade eminentemente amorosa, uma vontade que assente ao imperativo "ama o ser onde tu o conheceres, naquela ordem em que ele se apresenta à tua inteligência", e que graças ao amor se coloca em harmonia com a ordem cosmológica, não é difícil reconhecer no amor da ética rosminiana o eco de um outro amor que ecoa, não por acaso, no poema filosófico fundador do idioma italiano, pois Rosmini, como Dante, cerca de seiscentos anos antes dele, se refere a um só Amor, aquele "Amor que move o sol e as outras estrelas". 


\section{BIBLIOGRAFIA}

ABBÀ, Giuseppe (2011). História crítica da filosofia moral. São Paulo, Instituto Brasileiro de Filosofia e Ciência Raimundo Lúlio.

AGOSTINHO DE HIPONA, Aurélio (2010). Solilóquios. São Paulo, Paulus. ALBERTUNI, Carlos A (2010). O termo sindérese e sua introdução no pensamento medieval. In Revista Ágora Filosófica, $\mathrm{n}^{\circ}$. 11. Recife, Universidade Católica de Pernambuco.

ALVIRA, Tomás et alii (2014). Metafísica, São Paulo, Instituto Brasileiro de Filosofia e Ciência Raimundo Lúlio.

AQUINO, Tomás de (2009). Suma teológica. São Paulo, Edições Loyola. AQUINO, Tomás de (2002). Sobre a verdade. In Verdade e conhecimento, São Paulo, Martins Fontes.

BASSNETT, Susan (2003). Estudos de tradução, Lisboa, Fundação Calouste Goulbekian.

BERTI, Enrico (2002). As razões de Aristóteles, São Paulo, Edições Loyola. BRUNI, Leonardo (2011). Da tradução correta. In Revista Scientia traductionis, $\mathrm{n}^{\circ}$. 10, Florianópolis, Universidade Federal de Santa Catarina.

CAPELLA, Martianus (2007). Les noces de Philologie et de Mércure. Paris, Les Belles Lettres.

CÍCERO, Marco Túlio (2001). Sobre o destino. São Paulo, Nova Alexandria. CLEARY, Dennis (1992). Antonio Rosmini: introduction to his life and teaching. Dunham (Reino Unido), Rosmini House.

DAIBER, Dietrich L. (2007) Las traducciones medievales de la Metafísica de Aristóteles. In Revista Observaciones filosóficas, nº 4. Valparaíso (Chile), Universidad Católica de Valparaíso.

GARIN, Eugênio (1966). Storia della filosofia italiana, Turim, Einaudi.

GENTILE, Giovanni (1955). Rosmini e Gioberti: saggio storico sulla filosofia italiana del Risorgimento. Florença, Sansoni.

GENTILE, Giovanni (1937). Storia della filosofia italiana dal Genovese al Galluppi. Florença, Sansoni.

GILSON, Étienne (2007). Introdução ao estudo de Santo Agostinho. São Paulo, Paulus/Discurso Editorial. 
KANT, Immanuel (2011). Crítica da razão prática. São Paulo, WMF Martins Fontes. LAUDATO, Luís (2004). A liberdade de filosofar em Antonio Rosmini. Manaus,

Editora da Universidade Federal do Amazonas.

ORTEGA Y GASSET, José (1984). O que é filosofia? Rio de Janeiro, Livro IberoAmericano.

PEGORARO, Olinto (2006). Ética dos maiores mestres através da história, Petrópolis, Vozes.

RODRIGUES ALVES, Anderson M. (2015). Ser e dever-ser: Tomás de Aquino e o debate filosófico contemporâneo. São Paulo, Instituto Brasileiro de Filosofia e Ciência Raimundo Lúlio.

ROSMINI, Antonio (1990). Principi della scienza morale. Roma, Nuova Città Editrice.

ROSMINI, Antonio (2003). Nuovo saggio sull'origine delle idee. Roma, Nuova Città Editrice.

SARTRE, Jean-Paul (2007). O ser e o nada: ensaio de ontologia fenomenológica. Petrópolis, Editora Vozes.

SCIACCA, Michele F. (1962). História da Filosofia. São Paulo, Mestre Jou.

SCIACCA, Michele F. (s/d.). La filosofia morale di Antonio Rosmini. Roma, Fratelli Bocca Editori.

SCIACCA, Michele F. (2010). Filosofia e antifilosofia, São Paulo, É Realizações. SCRUTTON, Roger (2011). Kant, Porto Alegre, L\&PM Editores.

SOLOMON, Robert C. (2004). Espiritualidade para céticos - paixão, verdade cósmica e realidade no século XXI, Rio de Janeiro, Civilização Brasileira.

\section{Dicionários}

ABBAGNANO, Nicola. Dicionário de Filosofia. São Paulo, Martins Fontes, 2000.

BATTAGLIA, Salvatore. Grande Dizionario della Lingua Italiana, Turim, Unione Tipografico-Editrice Torinese, 2004.

DE MAURO, Tullio. Grande dizionario italiano dell'uso. Turim, Unione

Tipografico-Editrice Torinese, 2000.

FONTANIER, Jean-Michel. Vocabulário latino da filosofia, São Paulo, Martins Fontes, 2009.

GOBRY, Ivan. Vocabulário grego da filosofia, São Paulo, Martins Fontes, 2007. 
SPINELLI, Vincenzo. Dizionario completo italiano-portoghese (brasiliano) $e$ portoghese (brasiliano), Milão, Hoepl, 1988.

ZARADER, Jean-Pierre (org.). Dictionaire de philosophie, Paris, Ellipses, 2007.

ZINGARELLI, Nicola. Il Nuovo Zingarelli: vocabolario della lengua italiana, Bolonha, Zanichelli, 1988.

\section{Sites}

http://plato.stanford.edu/archives/sum2015/entries/antonio-rosmini

http://www.rosmini.it

http://www.rosmini-in-english.org/

http://www.grandidizionari.it/Dizionario_Italiano

http://www.treccani.it/scuola/tesine/filosofi_italiani_del_primo_ottocento/berti.html http://www.treccani.it/enciclopedia/antonio-rosmini-serbati_(Il-Contributo-italianoalla-storia-del-Pensiero:-Filosofia)/ 
2a. Parte

Antonio Rosmini

\section{Princípios da ciência moral}




\section{Sumário}

\section{Capítulo I}

Da primeira lei moral......................................................................... p. 59

Artigo I

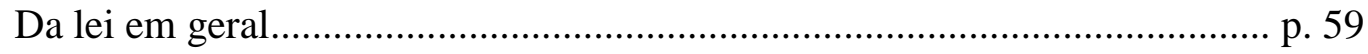

$\underline{\text { Artigo II }}$

Qual é a primeira lei............................................................................ p. 64

Artigo III

O princípio da moral é inserido no homem pela natureza.............................p. 68

Artigo IV

A primeira lei considerada em si mesma e no sujeito

p. 73

\section{Capítulo II}

A ideia do ser como regra suprema para julgar o bem em geral

p. 78

Artigo I

O que é o bem

p. 78

Artigo II

O que é o mal

p. 94

Artigo III

Como a ideia do ser é a noção com a qual se julga o bem universalmente..... p. 96

\section{Capítulo III}

A ideia do ser considerada como o princípio da eudemonologia................... p. 98

\section{Artigo I}

Definição da ciência eudemonológica............................................................ p. 98

$\underline{\text { Artigo II }}$

A ideia do ser e o princípio da eudemonologia. p. 100

Artigo III

O que é o bem subjetivo. p. 101

Artigo IV

Princípio próprio da eudemonologia .p. 104

\section{Artigo V}

O que é o bem de existência e o que é o bem de perfeição. .p. 105 


\section{Artigo VI}

O que é o mal de destruição e o mal de deterioração.

p. 108

\section{Artigo VII}

O que é o bem absoluto.

\section{Artigo VIII}

O que é a felicidade.

\section{Artigo IX}

Dignidade do sujeito inteligente.

\section{Capítulo IV}

A ideia do ser considerada como o princípio da moral p. 119

\section{Artigo I}

Resumo das doutrinas expostas.

\section{Artigo II}

O que é o bem objetivo.

p. 120

\section{$\underline{\text { Artigo III }}$}

Relação do bem objetivo com o bem subjetivo.

\section{$\underline{\text { Artigo IV }}$}

Relação entre o bem objetivo e o bem absoluto.

\section{Artigo V}

O bem objetivo dá origem ao bem moral, assim como o bem subjetivo dá origem ao bem eudemonológico. p. 127

\section{Artigo VI}

O bem moral é obra da vontade.

\section{Artigo VII}

No bem moral há ordem. p. 133

\section{$\underline{\text { Artigo VIII }}$}

$\mathrm{O}$ ato moralmente bom tem sempre por fim o bem de um ser inteligente e tende ao absoluto.

\section{Artigo IX}

Dupla dignidade do bem moral.

\section{$\underline{\text { Artigo } X}$}

\section{Capítulo V}


De que modo a vontade é a causa do bem e do mal moral.

p. 145

$\underline{\text { Artigo I }}$

O que é a vontade.

Artigo II

A livre vontade só começa a se manifestar no homem com a reflexão. p. 147

$\underline{\text { Artigo III }}$

De que maneira as ações e os afetos dependem da vontade...

p. 152

Artigo IV

O "reconhecimento" do ser que conhecemos é o princípio da justiça p. 165

Artigo V

A verdade é o princípio da moral p. 169

Artigo VI

Como se manifesta em nós a força da obrigação. p. 171

Artigo VII

Objeção resoluta. p. 175

Artigo VIII

Corolários acerca da liberdade da vontade.

\section{Capítulo VI}

Das potências que concorrem para o ato moral.

p. 180

$\underline{\text { Artigo I }}$

Potências morais por participação e potência moral por si. p. 180

$\underline{\text { Artigo II }}$

Intelecto moral p. 181

Artigo III

Razão moral. p. 182

Artigo IV

Razão eudemonológica

p. 183

Artigo V

Razão prática p. 184

Artigo VI

A razão moral é a fonte das leis subordinadas à primeira. p. 186

\section{$\underline{\text { Artigo VII }}$}

Definição da consciência moral. p. 187 


\section{Capítulo VII}

Dois elementos do ato moral................................................................... p. 188

\section{Artigo I}

A lei e a vontade, os dois elementos do ato moral.

p. 188

Artigo II

Da imputabilidade das ações.

p. 190

\section{$\underline{\text { Artigo III }}$}

Distinção entre o pecado e a culpa.

p. 191

\section{Artigo IV}

Da bondade moral do produzir e da bondade moral do aperfeiçoar.

\section{Artigo V}

Da gratidão

\section{Artigo VI}

Da bondade moral de aperfeiçoar.

p. 197

\section{Artigo VII}

Dos deveres aos quais corresponde um direito para os homens em relação aos quais são exercidos p. 199

\section{Artigo VIII}

Dos deveres para consigo mesmo p. 202 


\section{Princípios da ciência moral (I)}

Si oculus tuus fuerit simplex,
totum corpus tuum lucidum erit.

Lc. 11,34

\section{Capítulo I}

\section{Da primeira lei moral}

\section{Artigo I}

\section{Da lei em geral}

A lei (II) moral é uma noção da mente (1), que se usa para julgar a moralidade das ações humanas e segundo a qual se deve agir. Para que se possa, pois, fazer uso dessa noção e julgar as ações humanas, convém haver três condições, que são as seguintes:

1) Que aquela noção seja recebida na mente de quem julga.

2) Que o sujeito que tem aquela noção esteja consciente da sua aptidão para servir de regra nos juízos morais; e então pode-se dizer promulgada no sujeito, começando a ter propriamente a natureza e a força de lei (2).

3) Que seja aplicada pelo sujeito nas ações a serem julgadas.

Para que, então, possamos julgar a moralidade das ações, devem concorrer a existência da lei em nós, o que vem a ser o conhecimento, a sua promulgação e a sua aplicação com a qual se cumpre o juízo. 


\section{$\underline{\text { Notas }}$}

(I) N.T. Conforme Glossário, pág. 208.

(II) N.T. Cf. Glossário, pág. 208

(1) N.A. Ao dizer que a lei é apenas uma noção com a qual a mente julga, entendo reduzir a definição da lei a sua maior simplicidade filosófica. Mas a alguém talvez não fique de todo claro como a lei possa ser uma noção. Explicarei, pois, a minha ideia com um exemplo: tomemos essa lei moral: "ninguém deve fazer mal ao seu semelhante". Essa lei impõe uma classe de ações que me são vetadas, isto é, todas aquelas que fazem mal ao meu semelhante. Em virtude dessa lei, toda vez que me defronto com uma ação danosa, julgo-a vetada. Mas, para fazer esse juízo, para julgar que uma ação seja danosa ao meu próximo, de que me sirvo? Certamente, da noção que tenho de dano, porque, se eu não soubesse o que significa uma ação danosa e uma ação útil, se eu não tivesse essas duas noções, não poderia nunca distinguir a ação útil da danosa, como um cego de nascença que, não tendo a noção das cores, não pode distinguir o verde do amarelo, nem o azul do vermelho. É, pois, a noção de dano que me faz conhecer as ações danosas, enquadrando aquela noção em seu tipo. Uma noção, portanto, é sempre o princípio, ou seja, a regra do juízo.

Ora, haverão de me perguntar, a lei proposta "é ilícito causar dano ao semelhante" é também um juízo. De que noção, portanto, me sirvo como regra para formá-lo? Qual é a noção que produz essa lei? A noção do que é ilícito. Quando sei o que constitui a ilicitude de uma ação, então sei também que as ações danosas são ilícitas. E eis como essa noção mesma da ilicitude das ações é $l e i$, com a qual julgo a moralidade e a honestidade das ações, isto é, distingo as lícitas das ilícitas.

Nessa análise da lei proposta vê-se claramente que há uma ordem hierárquica, por assim dizer, nas leis, isto é, que existem as inferiores e as superiores, que as superiores são mais gerais, as inferiores mais específicas, que as leis específicas dizem o mesmo que as mais gerais, mas o dizem de modo mais parcial e explícito. Assim, a lei moral "não se deve causar dano ao seu semelhante" é inferior e menos geral do que a outra que diz "não se devem fazer coisas ilícitas". Mas em cada uma dessas leis, expressas em forma de proposição, há sempre uma noção, que é propriamente a que serve de regra à mente para julgar quais seriam as ações boas e quais as más, e, por isso, essa noção é essencialmente a lei; porque lei não quer dizer nada mais que uma regra com a qual se julga e discerne o certo do errado. 
Com esta observação, concorda rigorosamente a definição comum da lei: Lex est recta agendorum ratio (*), já que uma razão e uma noção são em si o mesmo, exceto que a noção difere da razão, por exprimir uma outra relação, assim como uma ideia, que não difere da noção e da razão senão em outro aspecto. E para que tudo prossiga claramente convém ter em vista as seguintes definições de razão e noção:

1) Chamo de noção uma ideia considerada sob esta relação, na medida em que ela me serve para tornar conhecidas as coisas. Assim, a ideia do dano é uma noção enquanto permite conhecer quais são as ações danosas.

2) Chamo de razão uma ideia considerada sob esta relação, na medida em que ela serve para raciocinar, ou seja, enquanto me serve como princípio para deduzir certas consequências sobre as coisas que percebo. Assim, a ideia mesma de dano é uma razão enquanto me serve para dela extrair a consequência de que, se pratico esta ou aquela ação, produzo um dano.

Segue daí que qualquer ideia pode ser uma noção e uma razão, porque qualquer ideia é uma espécie, que torna conhecidos os indivíduos, e é uma essência que é sempre o fundamento dos raciocínios.

(2) N.A. Pode parecer, à primeira vista, que não deva existir diferença entre a existência da lei no sujeito, isto é, o conhecimento da lei, e a sua promulgação; mas, num exame mais detalhado, vê-se que ela existe e é relevante. E no que se refere à lei positiva é fácil perceber que a lei pode ter tido sua promulgação legal, sem, entretanto, tornar-se conhecida de alguns indivíduos. Assim como e contrariamente à disposição do legislador, pode ser conhecida ainda antes de ser promulgada e proclamada como disposição obrigatória, ou seja, como lei. Mas não é igualmente fácil ver a diferença entre a existência da lei no sujeito e a sua promulgação quando se trata de lei natural. Poderia parecer que nada houvesse entre o conhecer e o não conhecer a lei e que, onde fosse conhecida, ela existisse e fosse promulgada; onde não fosse conhecida, ela nem fosse promulgada nem existisse no sujeito. Mas convém observar que a lei, como a definimos, é apenas uma noção, uma ideia, que serve de exemplo com que confrontar as ações e, assim, julgá-las. Ora, uma coisa é uma ideia e outra o uso dessa ideia; não causa espanto, por conseguinte, que se tenha uma ideia e que ainda se ignore seu uso. E, efetivamente, conhecemos nós todos os usos que podemos fazer de nossas ideias? Todos os partidos que delas podemos tirar? Todas as consequências que delas podemos deduzir? Certamente não; e amiúde dispomos de princípios na mente que permanecem inertes, de vez que não conhecemos seu uso. E afinal, qual é a diferença entre o filósofo 
e o homem comum, senão esta: que o primeiro extrai muito mais do que o outro as consequências dos primeiros princípios do raciocínio, que são comuns aos dois?

Não espanta, pois, que se conceba a existência em nós de uma ideia e simultaneamente a completa ignorância de seu uso sob qualquer relação particular; e ainda que essas duas coisas, a ideia e o conhecimento do uso que dela podemos fazer, estivessem sempre juntas, mesmo assim não seriam a mesma coisa, mas deveremos com a análise da mente separar uma da outra. Tomemos, então, aquela primeira ideia com a qual julgamos a moralidade das ações e suponhamos ignorar totalmente o seu uso como regra para fazer juízos: nesse caso, afirmo, haveria a existência da lei em nós, uma vez que afinal é aquela ideia a lei, que tem em si mesma toda a força; mas não estaria promulgada em nós, porque não sentiríamos ainda a força obrigatória daquela ideia, a sua aptidão para servir de regra para julgar as ações morais e discernir as boas das más. Vou ainda além e digo que a força que uma ideia possui em produzir por si consequências costuma restar-nos totalmente oculta, caso não entre em ação a experiência, que nos faça ver e experimentar essa sua força na realidade. Isso se verá mais claramente no nosso sistema moral. Nele, mostro que a primeira lei moral é a noção do "ser". Mas, embora todos tenham a noção do ser, quão poucos, no entanto, terão refletido que essa noção tem em si a eficácia para nos servir de regra para julgar a moralidade das ações, como estou por demonstrar! E quantos porventura já não se maravilham com essa proposição que aqui adianto? Isso deixa bastante claro que podem ter refletido sobre uma noção e, entretanto, não ter refletido sobre o seu uso. Aquilo que ocorre na ordem da reflexão, ocorre igualmente na ordem do conhecimento direto. Apesar de todos os homens terem a noção direta do ser, todavia, até que comecem a usá-la diretamente, não poderão sentir a força que ela tem em si mesma como lei moral. Assim, nada se opõe a admitir que ainda nos primeiros instantes da existência humana haja a ideia do ser, sem que o homem possa, contudo, dar-se conta de sua disposição para servir como lei; o que o homem só começa a fazer quando começa a usá-la, vale dizer, com a experiência. Aliás, a existência dessa ideia (e não de seu uso), anterior a toda experiência, é o que acredito ter submetido a uma rigorosa demonstração no Nuovo saggio sull'origine delle idee (**) (Novo ensaio sobre a origem das ideias).

Isto posto, assim raciocino: essa ideia é a lei (como se descobre depois de usá-la) conhecida em si mesma por todas as inteligências. Mas, permanecendo seu uso incógnito por algum tempo, isto é, até que surja a ocasião de aplicá-la e até que o 
homem a aplique, não importa seja esse tempo longo ou breve, ela permanece assim mesmo, promulgada pelo ser e comunicada ao indivíduo.

É por isso que acho necessário distinguir a existência da lei, no indivíduo, de sua promulgação nele mesmo: refiro-me à lei natural.

(*) N.T. Cf. Cícero, De legibus, liv. I, cap. 6; Lactâncio, Divinae Institutiones, liv. IV, cap. VIII; Tomás de Aquino, Suma Teológica, I-II, q. 90, a. 1.

(**) N.T. Todas as referências feitas nas notas de rodapé ao Nuovo saggio sulle origine dell'idee remetem aos volumes 3, 4 e 5 da edição da Opera Omnia di Antonio Rosmini, organizada pelo Istituto de Studi Filosofici (Roma) e o Centro Internazionale di Studi Rosminiani (Stresa), publicada pela Città Nuova Editrice, Roma, 2003. Doravante, a referência será feita simplesmente a Nuovo saggio. 


\section{Artigo II}

\section{Qual é a primeira lei}

É evidente que, às vezes, uma noção depende de uma outra mais geral, como as noções da espécie (I) dependem da noção de seu gênero (II) e a pressupõem, por exemplo a noção de homem depende da noção de animal e a pressupõe. Ora, em uma série de noções, cada uma das quais dependa de uma noção anterior e a pressuponha, deve haver um fim, do contrário ir-se-ia ao infinito; ou seja, deve-se, ao final, chegar a uma última noção, da qual dependem todas as outras, a qual seja pressuposta por todas; e esta, por sua vez, não tenha alguma outra da qual dependa, não tenha alguma outra anterior, e que além dela não se possa ir.

Ora, se as leis morais consideradas nas mentes são apenas outras tantas noções, é forçoso que também na série dessas noções, dessas leis, cheguemos a um fim, a uma última lei ou noção, a qual se pode dizer também primeira, já que essas duas palavras, última e primeira, exprimem somente duas relações do mesmo termo a quem as considera, encontrando-se no último lugar da série aquilo que, andando no sentido contrário, seria a cabeça e o começo da mesma.

A primeira lei é, portanto, aquela primeira ideia ou noção com a qual se formam os juízos morais. Mas qual é, pois, essa primeira ideia ou noção? Qual é essa primeira lei?

A ideologia (III) demonstra que há no homem uma ideia primeira e anterior a todas as outras, com a qual, como com regra suprema, todos os juízos se formam (3).

Admitida essa verdade, convém dizer que essa ideia primeira, princípio e fonte de todos os juízos, é também o princípio e a fonte dos juízos morais, sendo, assim, a primeira lei moral que aqui procuramos.

Essa ideia, com a qual a mente humana forma todos os juízos, é a ideia do ente universal (IV), ideia congênita no espírito humano e forma da inteligência. Digo forma da inteligência, porque da análise de todos os pensamentos humanos resulta que todos os pensamentos se formam na presença daquela ideia, de modo que sem aquela ideia não é mais concebível nenhum pensamento e, assim, o espírito dela privado permanece desprovido de inteligência, que só por aquela ideia se possui.

O ser universal deve ser, portanto, seguramente, aquela noção da qual nos servimos para produzir todos os juízos morais e deve ser, assim, a primeira lei moral.

E verdadeiramente convém observar que todas as coisas, todas as partes das coisas, todas as suas perfeições $(\mathbf{V})$, todos os seus valores, são apenas e finalmente 
outros tantos atos de ser: é sempre o ser diversamente atuado e limitado, que toma diversos nomes nas diversas coisas, porque essa palavra ser significa nada mais que a primeira atividade, toda atividade; o dizer o que é, é um dizer o que age, pois nada é se não age, devendo agir para ser, sendo, aliás, um agir aquele pôr-se, aquele manter-se si mesma, que a coisa faz sendo. Assim, nessa noção do ser se contém toda ação e, por isso, essa é aquela noção que mostra e que mede cada coisa, já que não podemos medir a atividade dos agentes, senão sabendo o que é ação; não podemos medir os diversos seres, senão sabendo o que é ser; e quando digo medir, digo distinguir, julgar, perceber intelectivamente, uma vez que não posso ter percebido intelectivamente se não sei, se não digo a mim mesmo que o tal ser é, que ele tem a atividade do ser de tal e tal modo e grau determinado, nem posso dizer isso a mim mesmo, não posso julgar isso, se antes não entendo o que quer dizer essa palavra ser, tomada em universal, que eu sempre pronuncio ao julgar.

Isto posto (e as maiores provas e declarações sobre isto qualquer um pode ver no que escrevi sobre a origem das ideias, a que me convém remeter aqui e ali ao leitor para não repetir infinitamente as mesmas coisas e refazer o já feito), resta, porém, ver como, conhecendo o ser, temos com isso só em mãos o bastante para julgar o bem e o mal moral: o que certamente há de parecer estranho a quem nunca refletiu sobre o assunto; parecendo, a bem dizer, que com o saber o que é o ser universal, podemos, contudo, saber o que são os seres particulares, mas não entender o que é o bem e o bem moral, não sendo claro à primeira vista nenhuma relação entre os seres e as ações morais. Eis porque é meu dever comprovar o que digo e aproximar essas duas coisas do ser das coisas e do bem e mal moral, e é isso exatamente o que me proponho a fazer um tanto extensamente com todo este livro, que não tem finalmente outro escopo além desse. Mas, embora o pouco que dissemos deva bastar para nos mostrar que, em geral, a noção de que falamos deve servir para nos prestar tal serviço, ainda que não vejamos como, não temos o direito de refutar semelhante verdade, depois do que foi acenado, mesmo se ainda não conhecemos o modo com que ela o faz. Porque a quem quisesse refutá-la, conviria refutar primeiro as provas com as quais demonstrei que a ideia do ser é a regra de todos os juízos (4), ou ao contrário que negasse a definição por mim anteriormente dada da lei como regra dos juízos morais. Mas, desde que estão firmes esses dois pontos, convém que esteja também o terceiro, ou seja, que aquela que é a primeira regra de todos os juízos seja também a primeira na classe especial dos juízos morais, ou seja, que é a primeira lei moral. 
E, como a ideia de ente universal constitui o lume da razão (5), por isso não sem verdade em alguns filósofos se exprime a primeira lei moral com a seguinte fórmula: "segue a razão"; mas seria expressa mais acuradamente nessa outra: "segue, no teu agir, o lume da razão".

Essa é a fórmula mais geral que se pode ter na ciência moral.

Digo, pois, que melhor e mais acuradamente se exprime a primeira lei com a fórmula: "segue, no teu agir, o lume da razão", do que com a anterior "segue a razão", pois, a bem dizer, a razão humana nem sempre é uma escolta fiel, mas o seu lume, se ela o segue, sim. A razão é a faculdade com a qual o espírito humano aplica a ideia do ser e assim raciocina, de modo que o raciocinar nada mais é do que aplicar essa ideia (6). Ora, sendo o espírito humano o autor dessa aplicação, ele bem frequentemente erra ao fazê-la, porque é falaz e, assim, a razão é falaz por ser uma potência de um espírito limitado e falaz. Ao contrário, o próprio lume da razão não admite em si o erro, porque ele mesmo não depende do espírito humano, não é pelo seu trabalho adquirido e procurado, mas é nele inato, nele colocado e inspirado pelo Criador; aliás, o ser, que é esse lume que ilumina o espírito e o faz inteligente, considerado bem, é de uma absoluta imutabilidade, é eterno, necessário, é a própria verdade em uma palavra, como demonstrei demoradamente no livro sobre as ideias (7). Logo, não é a razão que verdadeiramente constitui a suprema lei moral, mas sim a ideia do ser, o lume de que aquela potência faz uso e do qual, ao se aproximar, acerta e, ao se afastar, erra.

Só essa observação afasta um grande número de equívocos e revoga um grande número de erros nos quais incorrem outras teorias que ou divinizam o homem ou o embrutecem. É assim que alguns, observando a excelência e a infalibilidade do lume da razão, confundem esse lume com a razão, que é a potência que o usa, e tornam a razão humana temerária e soberba, o homem legislador e Deus no universo moral; alguns outros, observando ao contrário a falácia da razão humana e desconhecendo aquele elemento divino que nela resplende (a ideia do ser), calcam o homem lá para baixo, condenando-o a um erro perpétuo ou a andar às apalpadelas nas trevas em busca da verdade, sem nunca ter a certeza de encontrá-la, nem o levando a um verdadeiro estado moral. Mas, se não consente a brevidade desta obra que eu persiga esses sistemas errôneos que despejam uns e outros (VI) em extremos viciosos, não me eximirei, todavia, de apontá-los e descrevê-los, para que possam ser evitados. 


\section{$\underline{\text { Notas }}$}

(I) N.T. Espécie: Cf. Glossário, pág. 210

(II) N.T. Gênero: Cf. Glossário, pág. 210

(III) N.T. Ideologia: Cf. Glossário, pág. 211

(3) N.A. Quem quiser ver as provas dessa verdade-mãe as encontrará no Nuovo saggio, no qual as expus exaustivamente. Ali demonstrei que a noção do ser tem diversos usos, que nesses diversos usos ela se torna necessariamente todos os princípios da razão e que, em última análise, todos os raciocínios mediante esses princípios. Quem quiser ver como todos os primeiros princípios do raciocínio são, enfim, somente a ideia do ser aplicada veja a dedução desses princípios da ideia do ser no volume 2 da obra citada, nas páginas 130-131, e, no vol. 3, páginas 319-320 e segs.

(IV) N.T. Ente universal: Cf. Glossário, pág. 210.

(V) N.T. Perfeição: Cf. Glossário, pág. 211.

(4) N.A. No Nuovo saggio, vol. 2.

(5) N.A. Ver Nuovo saggio, Vol. 2, pág. 76-77, § 480-482, e as notas do § 490, pág. 81, e do $§ 495$ (particularmente a segunda nota), pág. 84. Do mesmo modo, no Vol. 3, págs. 71-92, § 1112 a 1136.

(6) N.A. Seção 6 do Nuovo saggio.

(7) N.A. Idem.

(VI) N.T. Traduzi quinci e quindi, por aproximação, de acordo com o contexto em que a expressão aparece. 


\section{Artigo III}

\section{O princípio da moral é inserido no homem pela natureza}

Esta verdade descende das antecedentes.

Se a ideia do ser é ingênita e se ela mesma exerce o papel da primeira lei, daí decorre que trazemos inserida em nossa alma, pela natureza (I), toda a moral em seu germe, ou seja, aquela primeira lei, que é o princípio e a fonte de todas as outras, que é o ditame do honesto e do justo.

E a necessidade disso se prova também porque se não tivéssemos ingênito o princípio da moral, nunca seria possível adquiri-lo; não o teríamos, ainda que o consenso do gênero humano nos dissesse que o temos.

Assim como não podemos conhecer senão pela natureza (I) sensível, a qual apresenta somente fatos e não suas leis e razões, que de nenhum modo podem ser recebidas pelos sentidos corpóreos, mas, sendo essencialmente desconhecidas aos sentidos, são evidentes apenas às naturezas (I) inteligentes. De modo que ou convém negar a moral ou reconhecer infuso em nós o seu princípio; e, assim, acreditamos certamente que todos aqueles que rejeitam a teoria do ente que publicamos são forçados (mesmo que não queiram) a considerar impossível a moralidade das ações.

Nem é minha essa teoria que reconhece impressa na natureza humana um lume que a ensina a discernir o bem do mal, nem é nova: é uma doutrina tradicional de toda a boa Antiguidade e principalmente da tradição cristã, que foi obscurecida pelo presunçoso movimento que fizeram as inteligências do século XVIII, com o qual, aparentemente, os homens tentaram se emancipar de todos os séculos precedentes e renegar a fé filosófica de seus pais, assim como cada um tendia a emancipar-se da sociedade de seus contemporâneos, para não dever nada a ninguém além de si mesmo, do que lhes ocorria rejeitar uma doutrina somente porque era antiga, porque era comum, isto é, pela razão que torna uma doutrina respeitável e veneranda.

A tradição de que falamos, antes do cristianismo, foi estabelecida, entre outras, nessa passagem daquele grande colecionador do saber antigo, Marco Túlio Cícero: "Creio", disse ele, "ter sido esta a sentença dos mais sábios, que a lei moral não foi já extraída do engenho dos homens, nem de algum decreto dos povos, mas, sim, que é algo de eterno, uma sapiência que preside o comandar e o proibir, e que rege o mundo inteiro"(8). Se a lei, portanto, não pode ser formada e adquirida, convém dizer, de acordo com os mais sábios que viveram antes de Cristo, que o homem a tinha em si por natureza. 
A tradição da mesma verdade, após o cristianismo, encontra-se em qualquer página dos escritores eclesiásticos. Ao meu escopo, bastam as duas passagens seguintes: "Há”, diz São Jerônimo, "nas nossas almas uma tal santidade natural por Deus impressa, a qual, residindo na parte mais elevada do nosso espírito, exercita o juízo do ruim e do reto"(9). Nessa passagem, atente-se naquela expressão, a de que essa santidade natural, que é em nós congênita, reside na parte mais elevada e, propriamente, segundo a expressão latina, na cidadela da alma, expressão que convém como uma luva a nossa doutrina, que constitui por primeira lei moral e única inata, a altíssima ideia do ser, de onde se originam e tomam forma todas as outras ideias e todo pensar humano. Por isso, em que outra parte mais elevada e mais fortificada do espírito pode ela estar, senão na sede da luz do ser, isto é, onde está a nascente da vida intelectiva, o princípio simplicíssimo de todos os juízos, o lume, enfim, da razão? Eis por que certamente, pelos mestres cristão, entre os quais São Boaventura, esse lugar altíssimo e fortíssimo do nosso espírito, onde não entra erro e onde está a primeira norma dos pensamentos e também das ações, foi chamado, de a ponta, ou seja, de ápice da alma.

A segunda passagem que quero mencionar é de São Ivo: “Já vimos”, disse ele, “que por Deus, primeira verdade, é inserida nas mentes humanas a ideia do reto, pela qual todo homem, sem mestre, sem lei escrita, sem juiz, somente com a sua sindérese (II), discerne o justo do injusto. Com essa luz Deus ilumina todo homem que vem a este mundo" (10).

Quanto converge tal passagem com o que dizemos, qualquer um pode ver, se bem a considerar. Diz aquele escritor que há no homem uma ideia inata e que essa ideia é aquela luz com a qual Deus ilumina todo homem nascido neste mundo e que ela é uma ideia do reto, de tal modo que com ela o homem discerne, sem que lhe seja ensinado, o justo do injusto. Ora, não é essa, sem tirar nem pôr, a nossa teoria? Também nós dizemos que aquela luz, com a qual Deus ilumina cada homem que vem ao mundo, isto é, o lume da razão, é só uma primeira ideia; também nós dizemos que essa ideia não vem dos sentidos, mas é inspirada no homem por Aquele que o criou; também nós dizemos que essa primeira ideia que forma o lume do homem racional é a medida do certo e do errado. Somente que, acrescentando nós a análise dos múltiplos pensamentos humanos, procedemos a uma outra pesquisa - sobre qual é entre todas as outras essa ideia primeira e altíssima, da qual todas as outras descendem e que por isso é o verdadeiro lume do homem em todos os seus conhecimentos - e descobrimos que ela não é outra senão a ideia do ser, ideia que em todas as outras ideias encontra-se 
mesclada como um elemento necessário à sua existência, o elemento formal, e na qual não se encontram mescladas outras ideias, ideia que por isso é a única verdadeiramente simples, embora fecundíssima em sua simplicidade (11). 


\section{$\underline{\text { Notas }}$}

(I) Natureza: Cf. Glossário, pág. 211

(8) N.A. Cicero, Marco Túlio, De legibus II, 4.

(9) N.A. São Jerônimo, Epistola ad Demetriadem.

(II) N.T. Sindérese: Cf. Glossário, pág. 212

(10) N.A. Divi Ivonis Carnotensis Episcopi (*), Opera Omnia, "Decreti”, parte II, cap. 4 e parte XI, cap. 72 .

(11) N.A. Duvidei certo tempo de que os antigos tivessem visto como a ideia do ser é anterior a todas as outras; é aquela de que todos os próprios princípios da mente descendem. Aristóteles considerava como primeiro o princípio da não contradição, o qual, no entanto, é posterior à ideia do ser e também àquele que chamo de princípio de conhecimento (Nuovo saggio, vol. 2, págs. 131 e segs.), o qual se forma diretamente da ideia do ser. Abandonei a dúvida quando encontrei uma passagem de um escritor sagacíssimo que, analisando o princípio de não contradição, concluiu que ele também deve ser precedido pela ideia do ser, à qual, por isso mesmo, reivindica o primeiro posto entre as intelecções humanas, embora o faça, modestamente, como expositor de doutrina alheia e não autor da própria. Convém ser justo e dar crédito a uma observação tão aguda que nos chega da segunda metade do século XIII: o autor a que me refiro é Alexandre de Hales (**), no livro em que expõe a metafísica de Aristóteles.

Ao procurar as características do primeiro princípio de todos os raciocínios humanos, o estagirita encontra estes três: 1) que seja sólido e notório; 2) que seja absoluto e incondicional; 3) que não se possa demonstrar e seja naturalmente dado, passando a demonstrar que isso se aplica precisamente ao princípio de não contradição.

$\mathrm{O}$ astuto frade não se contenta com a posição do filósofo e a questiona. Diz ele: "São duas as operações do intelecto; uma com a qual ele percebe, outra com a qual decompõe e divide as coisas percebidas. Ora, tanto a uma quanto a outra dessas operações há algo de primeiro, algo que é encontrado como seu primeiro termo. Na primeira operação, esse primeiro objeto é o ente, porque nada se pode conceber antes de tê-lo concebido, porque a entidade penetra e se aprofunda em todos os conceitos (quer dizer, o ente é pressuposto em todos, como se fundamento).

Na segunda operação, por sua vez, o primeiro objeto é o princípio de não contradição, o qual se funda no ente”. Dessa nobilíssima doutrina, ele conclui: “Assim como o ente é primeiro na primeira operação do intelecto (que os antigos chamavam de inteligência 
dos simples); na segunda, é primeiro o princípio da não contradição. Portanto, assim como todos os conceitos simples se resolvem no ente, todos os conceitos compostos se resolvem no princípio de não contradição.” Do que decorre que a ideia do ente é, absolutamente falando, a primeira intelecção da mente. Confesso que me deixou maravilhado essa passagem, na qual o lugar do ente entre as ideias é encontrado e definido com tanta clareza e na qual, comentando Aristóteles e talvez sem percebê-lo, Alexandre de Hales lhe acrescenta uma preciosíssima verdade. Creio ser útil ao leitor tê-la compendiado e traduzido.

(*) N.T. Ivonis Carnotensis é a designação latina de São Ivo de Chartres (1040-1115), bispo desta cidade francesa e canonista que se destacou durante a Questão das Investiduras, o mais significativo conflito entre Igreja e Estado na Europa Medieval. Suas obras sobre Direito Canônico exerceram influência sobre a Escolástica.

(**) N.T. Alexandre de Hales nasceu circa 1185, na cidade que hoje se chama Halesowen, no condado de Shropshire, Inglaterra. Morreu em Paris, em 1245. Recebeu do papa Alexandre IV o título de Doctor Irrefragibilis e também desfrutava da alcunha de Theologorum Monarcha. É conhecido por refletir sobre as obras de muitos pensadores medievais, especialmente Santo Agostinho e Santo Anselmo, mas, ao contrário dos comentadores de sua época, tem como característica própria o de evidenciar nos comentários que elaborava seus próprios interesses e os de sua geração. Ao comentar obras de autoridades, Alexandre não só resenha seu pensamento, mas extrai conclusões e as expande, nem como deixa claro sua concordância ou discordância, o que Rosmini evidencia nesse trecho, no que se refere a Aristóteles. Foi o primeiro franciscano a ocupar uma cátedra na Universidade de Paris, onde teve discípulos importantes, dos quais se pode destacar São Boaventura de Bagnoregio. 


\section{Artigo IV}

\section{A primeira lei considerada em si mesma e no sujeito}

A observação que se faz sobre o modo pelo qual o intelecto conhece, assegura esta verdade: que o intelecto, ao contrário do sentido, percebe objetivamente, isto é, fixa-se em um objeto distinto de si (I); portanto, o sujeito inteligente, apenas com o seu próprio entendimento, atenta a um objeto diferente de si, abandonando a si mesmo para ocupar-se da coisa que lhe é presente: esta é a condição da operação intelectual; que o seu termo seja percebido como distinto daquele que percebe, ou ainda, excluindo quem percebe, e que haja uma tal oposição entre ele e o percebido, de modo que um não possa ser o outro ao mesmo tempo, nem perceber-se entre si com o mesmo ato, de modo que quem percebe, nesse ato com que percebe, não é ao mesmo tempo o percebido.

Essa diversidade ou oposição que a observação revela entre quem percebe, enquanto percebe, e o percebido, enquanto percebido, não é ilusória, mas real (12).

Portanto, também entre o ser percebido e o sujeito que o percebe deve haver essa distinção e daí a necessidade de considerar o ser em si mesmo e enquanto empregado por aquele sujeito que dele tem noção.

Apesar de o sujeito que percebe ser distinto do objeto percebido pela própria natureza da percepção intelectiva, há, todavia, uma ligação entre quem percebe e o que é percebido, ligação em que consiste o próprio entendimento.

Tal ligação entre o objeto percebido pelo intelecto e o sujeito que percebe é tão íntima, que desses dois princípios se faz um só indivíduo, sem jamais se confundirem um no outro. Portanto, vê-se que o lume da razão (o ser) liga-se ao sujeito-homem de modo que passa a formar parte da natureza humana, neste sentido: que a humanidade não mais existiria se lhe fosse tirado o lume da razão (13).

Essa íntima ligação levou não poucos a perderem de vista aquela duplicidade natural, por assim dizer, do sujeito humano, desse sujeito que, essencialmente inteligente, tem essencialmente um objeto universal do seu entendimento. Esse engano, esse haver confundido o objeto essencial com o sujeito inteligente, com o próprio sujeito, gerou muitíssimos erros; uma vez que se atribuiu ao sujeito aquilo que só pertencia ao objeto e, ao contrário, se deu a este o que pertencia àquele, do que nasceram aqueles dois sistemas errôneos de ciência moral, aos quais entendo que finalmente se podem reduzir os erros relativos à doutrina moral.

O primeiro desses dois sistemas é o que atribuiu ao sujeito o que era do objeto. 
Sendo o objeto (e, quando digo objeto, digo a suprema lei moral) dotado de alguns caracteres divinos, como apontei, que são a imutabilidade, a eternidade, a universalidade e a necessidade, todos esses caracteres foram atribuídos por esse gênero de filósofos ao sujeito humano e, portanto, divinizaram o homem. Esses filósofos nos falam com um tom cheio de entusiasmo do divino do homem, de quem fazem a lei por si mesmo. Esse sistema do mais célebre dos filósofos alemães do século passado (II) recebeu o nome de autonomia (III), isto é, de "lei de si mesmo" (14).

O segundo sistema errôneo peca pelo vício contrário e atribui ao objeto, isto é, à lei moral, aquilo que é do homem-sujeito. Já que, sendo o homem variável, efêmero, limitado e contingente, os filósofos de quem falamos se esforçam ao máximo para descrever-nos a lei moral dotada desses caracteres, pretendendo fazê-la também sujeita a variação perpétua, segundo o variar dos climas, dos costumes, das educações e das estirpes. Esse sistema, que anula qualquer legislação moral, foi há pouco tempo fervorosamente ensinado e divulgado em quase todas as escolas da Europa, ao lado da filosofia de Locke e dos outros sensistas que o produziram; embora tenha sido sempre refutado e contradito, senão tanto pelos escritos dos doutos, pelo instinto infalível que os povos cristãos nunca perdem, com o qual afastam de si qualquer doutrina perniciosa tão logo ela se apresenta, ainda que ela não seja cientificamente refutada e contestada, e por mais que seja adornada de sofismas e aparências lisonjeiras. Mas parece que houve um tempo no qual todo o reino da filosofia foi dominado por esses dois sistemas excessivos. Nem Kant enumera outros quando, ao seu sistema da autonomia, contrapôs aquele da heteronomia (IV), isto é, da lei recebida externamente a nós. Por isso, a mim parece que naquele sistema da heteronomia, que o filósofo de Könisberg contrapõe ao seu, não entendesse ou não tivesse em mira senão o sistema daqueles que querem gerar em nós também as noções morais a partir do uso dos sentidos externos (15).

Entre esses sistemas morais que consideram a lei oriunda de um princípio externo ao homem, isto é, diverso de nós, convém distinguir diligentissimamente dois, um verdadeiro e outro falso: isto é, o sistema daqueles que se empenham em extrair a moral das sensações, a bem da verdade com um esforço vão e com a destruição da moral toda; e o sistema daqueles que veem no homem um princípio distinto dele mesmo, mas com ele intimamente ligado por uma lei da natureza; e estes, partindo de tal observação, que fazem sobre a constituição da natureza intelectual e moral, deduzem toda a série das outras leis morais, que conectam e atribuem àquele supremo e maravilhoso princípio, que resplandece no ânimo e goza por sua natureza de 
imobilidade e consistência, contra o qual não pode nenhuma força criada ou incriada, e ao qual deve obedecer toda inteligência finita, e obedece, nas palavras de Bossuet (V), à própria divindade.

Mas os dois sistemas que consideramos certamente pecam, se bem considerados, por uma falta de observação; porque tanto um como o outro ultrapassam e esquecem um elemento da natureza humana, por isso sua observação dessa natureza permanece imperfeita. O primeiro sistema, que diviniza o homem, não atenta devidamente à natureza do espírito, o qual é meramente passivo em relação à lei moral; ele recebe em si essa lei, mas não a forma; é um súdito, a que a lei se impõe e não um legislador que a impõe. Ao contrário, o segundo sistema perde totalmente de vista aqueles caracteres fulgentíssimos de onde emana a lei moral, os quais não se deduzem já por raciocínios, mas são observados diretamente como muitos outros fatos; portanto, os sistemas de Locke e de Helvetius (VI) desconhecem e ocultam aquela força irresistível da lei, a qual obriga e liga tanto quem a observa quanto quem a viola, estando presente em todos impassivelmente, dotada de uma invencível autoridade.

Entre esses dois sistemas, pois, ambos insatisfatórios por falta de observação completa, tem lugar um terceiro, fundado numa observação total e imparcial, o qual não se restringe arbitrariamente ao sujeito, buscando tudo deduzir desse único princípio, nem se fecha tão sistematicamente e se ocupa tanto da excelência da lei, que esqueça a propriedade do espírito que a percebe (16), mas diligentemente considera o sujeito e o objeto, e o modo admirável pelo qual os dois se fazem uma coisa só, sem porém confundir-se, de modo que as propriedade de cada um permanecem separadas e distintas, e, assim como do objeto vem toda a força obrigatória, do sujeito vem o sentimento e a consciência da mesma. 


\section{$\underline{\text { Notas }}$}

(I) N.T. No original, o que traduzimos por "fixa-se em um objeto distinto de si" é "pone un diverso da sé", literalmente, "põe um diverso de si", "diferente de si", frase cujo sentido nos pareceu obscuro. Para entendê-la, recorremos à traducão inglesa, onde se lê "focuses its attention on an object different from itself".

(12) N.A. Ver Nuovo saggio, vol. 3.

(13) N.A. Aqueles que põem o homem a nascer privado de qualquer noção tornam-no realmente privado de inteligência e pretendem em seguida explicar, a partir das sensações adquiridas, o imenso salto pelo qual deve se desenvolver e se educar, para passar de animal a homem. É impossível supor o desenvolvimento sem um germe intelectivo, que esses filósofos negam ao homem: são forçados a conceber algo incompreensível, isto é, que seja criado no homem o intelecto em algum ponto não assinalável de sua vida.

(II) N.T. Isto é, o século XVIII. Trata-se do kantismo.

(III) N.T. Kant, Immanuel, Crítica da razão prática: I, § 8: “A autonomia da vontade é o único princípio de todas as leis morais e dos deveres que lhe correspondem".

(14) N.A. Também São Paulo, dizendo que os pagãos tinham a lei natural, que lhes servia de lume, falou que, privados de lei, isto é, de lei escrita, "eram sua própria lei", ou seja, tinham lei natural. A expressão tem a sua verdade naquela união que, do lume da razão e do homem, faz uma coisa indivisível. Assim se deve interpretar a expressão do apóstolo. Seria errôneo entendê-la de outro modo, no sentido do sistema que combatemos, no qual o sujeito (o homem) e o objeto (o ser) não estão apenas unidos individualmente, mas ensimesmados e confusamente perdidos.

(IV) N.T. Kant, Immanuel, Crítica da razão prática: I, § 8: “qualquer heteronomia do livre-arbítrio não só não é propriamente a base de alguma obrigação, como em geral é contrária ao princípio dessa e à moralidade da vontade".

(15) N.A. Neque enim creatura legem tribuit, sed accepit, et servat acceptam. Santo Ambrósio, Hexaemeron, I, cap. VI.

(V) N.T. Cf. Bossuet, Jacques, De la connaissance de Dieu et de soi même e Traité du livre-arbitre, Oeuvres, vol. 11, Paris, 1856.

(VI) N.T. Helvetius, Claude Adrian (Paris 1715-1771), filósofo iluminista, cujas principais obras em que expõe sua filosofia moral são: De l'esprit (Paris, 1758); De l'homme, de ses facultés intelectuelles e de son éducation (Londres/Amsterdam, 1772, 
póstumo). Helvetius parte do princípio que o único motor do homem é o amor próprio e, portanto, o prazer.

(16) N.A. Desse segundo erro, está manifestamente impregnado o novo gênero de platonismo, que procura se estabelecer na França, vindo da Alemanha sob o nome de filosofia eclética $(*)$. Munida de um certo esplendor de ideias, essa filosofia pode facilmente enganar os espíritos mais nobres e generosos. Já adverti muitas vezes os italianos de se resguardarem do vício funesto que esse sistema esconde em si mesmo. Fi-lo ultimamente no Nuovo saggio, onde refuto pormenorizadamente seu erro capital. (*) N.T. Ecletismo: nome introduzido na terminologia filosófica no início do séc. XVIII e difundido pela Enciclopédia francesa (1755). Rosmini se refere à filosofia de Victor Cousin (1792-1867), eclético espiritualista, cujo pensamento refutou no Nuovo saggio, vol. 3, cap. III, pág 294 e segs. 


\section{Capítulo II}

\section{A ideia do ser considerada como regra suprema para julgar o bem em geral}

Voltemos, então, ao nosso propósito, do qual nos afastou um pouco uma digressão, que me parecia útil para esclarecer a importância da doutrina que estamos expondo. Estávamos empenhados em explicar o modo pelo qual a noção do ser pode nos servir de lei moral, de noção apta a determinar o que é direito e o que é perverso.

De que maneira, portanto, a ideia do ser é a suprema lei moral? Ou seja, como sucede que essa ideia seja a suprema regra, o critério supremo com o qual julgamos a moralidade das ações humanas?

Para entrarmos nessa investigação gradativamente, começaremos por ver como a noção de ser pode nos servir para julgar o bem em geral e depois passaremos a ver com mais facilidade como ela pode nos servir para julgar o bem moral.

Com esse fim devemos logo procurar o que é o bem.

\section{Artigo I}

\section{O que é o bem}

Partamos de um ponto inquestionável, tomemos aquela definição do bem que nos é dá o senso comum, com a qual todos os homens que usam a linguagem concordam e analisando-a acuradamente, procuremos os elementos que ela contém, os quais elementos, inicialmente separados, e, depois, ordenadamente recompostos, nos darão facilmente a definição filosófica do bem de que necessitamos.

É, portanto, incontestavelmente verdadeiro que aquilo que apetece (I), os homens costumam chamar de bem.

E é certo que nenhuma coisa pode chamar-se bem, se é antes detestada do que apetecida; mas, sim, enquanto move agradavelmente essa nossa faculdade de apetecer, que não é nada senão a faculdade que nos leva a gozar do bem. Creio que com essa proposição todos concordam e que o absurdo do contrário não precisa de demonstração. No entanto, essa proposição nos leva a refletir que normalmente os homens entendem por bem uma relação das coisas com a faculdade de apetecer.

Mas quais são essas coisas que movem o apetite? Quais são as coisas a que compete o nome de bem? Essa é, portanto, a pesquisa que deve nos conduzir a uma noção do bem mais determinada e completa.

Se uma coisa é bem enquanto apetecida, deve existir primeiro um ser capaz de apetecer. Sem esse ser, a noção de bem não poderia existir, uma vez que uma relação 
não pode ser concebida sem os dois termos entre os quais ela se estabelece; e o bem, como dissemos, é uma relação entre as coisas e um ente que delas apetece.

Dado, então, esse ser, é evidente que ele, antes de tudo, tem de apetecer a si mesmo (a própria existência, a própria conservação), e depois tudo que pode torná-lo perfeito e mais completo.

E em verdade não faria sentido, nem mesmo que isso se quisesse dizer, falar em um ser que tivesse uma faculdade de apetecer voltada essencialmente ao ódio de si mesmo, uma faculdade que tendesse somente à própria deterioração e destruição. A noção de um ser como esse é contraditória em si mesma, pois não se pode apetecer o nada e a esse ser apeteceria o nada, se verdadeiramente lhe apetecesse a própria destruição e todos aqueles passos de sucessivas imperfeições a que o conduzem à destruição.

Aliás, o que é, enfim, essa faculdade de apetecer? Vamos examiná-la atentamente. Ela não pode ser outra coisa, nem os homens podem fazer dela outro conceito, senão o de uma faculdade pela qual um ser tende a gozar da perfeição ou do aprimoramento que recebe ou recebeu, assim como no próprio conceito da faculdade de apetecer se compreende já dada a tendência a deleitar-se de si, a amar a si mesmo e a todos os bens, a todas as perfeições da natureza, e o deleite é ele mesmo um bem para quem o experimenta.

Mas consideremos ainda mais atentamente a expressão "goza-se das perfeições ou das qualidades da própria natureza". Nela aparece tanto a perfeição e a qualidade dos quais se goza, quanto o gozo da perfeição e da qualidade. Aqui, portanto, há dois elementos contidos na definição comum “o bem é aquilo que apetece": isto é, há o gozo, primeiro elemento; e a perfeição de que se goza, segundo elemento. Aparentemente, não pode existir dúvida acerca da distinção real dessas duas partes do bem.

Ora, logo se levanta uma questão na mente. Essas duas partes, ou elementos do bem, indicados pelo senso comum que diz "ser o bem aquilo que apetece", são ambas necessárias para constituir o conceito de bem ou uma apenas basta? Quando nomeio as perfeições de uma natureza, não nomeio já com isso outros tantos bens? Não os nomeio ainda antes de haver introduzido ou apontado alguma faculdade de apetecer? Não se costuma atribuir graus de perfeição e de bens também às naturezas inanimadas e insensíveis? Não se costuma dizer que todas as coisas são boas, cada qual considerada em sua própria natureza? Não parece que o senso comum dos homens costuma tomar por sinônimos perfeição e bem, e conceber as perfeições das diversas naturezas como 
outros tantos bens independentemente do sujeito que as percebe e que as apetece sensivelmente?

Antes de responder essa questão, seja-me permitido fazer uma outra e respondêla, pois isso aplanará o caminho para responder mais claramente a primeira; e a nova pergunta que faço é: poderia o homem ter tido a ideia de perfeição, quando ainda não tinha a faculdade de apetecer?

Primeiramente, esclareço que não se deve confundir aqui a faculdade de apetecer e fruir, com a faculdade de conhecer; antes, que as considero como duas faculdades essencialmente distintas entre si. Sei que podemos conhecer os bens de que não gozamos e que não apetecemos. Sei que podemos saber que há coisas que são bens, e, todavia, não são bens para nós, mas para outros seres diferentes de nós; que, mesmo sem haver a experiência deles em nosso apetite, podemos formar o conceito de certos bens. Não é isso que estou me perguntando. Quero saber se, sem que houvéssemos jamais sentido ou apetecido algum bem, poderíamos ter noção dele. E, para não haver equívoco sobre a palavra apetecer, repito que a entendo como a faculdade de tender a certas coisas para delas gozar, faculdade que supõe aquela de sentir prazer das perfeições da natureza e que com esta se confunde.

Depois disso, digo que a uma tal pergunta se deve responder negativamente e essa minha opinião já é conhecida de todos que sabem minha maneira de pensar sobre as origens dos conhecimentos humanos; ou seja, afirmo que se não tivéssemos nunca experimentado o prazer das perfeições da nossa ou de outra natureza, não poderíamos formar qualquer ideia das perfeições de nenhuma natureza. Pois é claro que um ser sensível só pode ter uma via de perceber as perfeições da própria natureza, que é sentilas, assim como o próprio intelecto só pode pensar um bem após o sentimento tê-lo posto diante dele e o apresentado a ele (1). Tendo respondido assim à segunda questão que coloquei, de modo que ela, permanecendo insolúvel, não viesse a perturbar o progresso do nosso raciocínio, retornemos agora à primeira.

Se não se podem perceber nem por isso conhecer os bens e as perfeições das diversas naturezas, sem ter deles algum sentido e apetite, são, pois, perguntava-se, igualmente necessários esses sentido e apetite para a existência delas? Isto é, podem existir uma perfeição, um bem, sem que seja sensível e apetecível? Era essa a questão inicial, que irei responder.

Raciocino do seguinte modo: é claro que, para saber que uma coisa é uma perfeição, convém sabermos que aquela coisa é agradável à natureza que o possui ou à 
qual se refere, e agradável não lhe pode ser senão de um modo sensível. E, na verdade, em relação a um ser que não sente, as perfeições não existem; um ser privado de toda sensação não existe em si mesmo, mas somente em relação àquele que o sente (2). Somente quem sente a si mesmo existe em si mesmo; a anulação do sentir é a anulação daquela relação entre a natureza do indivíduo e o indivíduo: em suma, onde não há sentimento, não há um Eu e certamente não há um sujeito. Essa observação me parece muito importante e é dela que convém partir para entender corretamente o pensamento que quero exprimir. Isto é, afirmo que as naturezas privadas de toda sensibilidade são com certeza indiferentes e nulas a todas às suas próprias perfeições, a começar pelo primeiro grau de perfeição, que é a existência, e até o último; e, assim, que essa existência e essas outras propriedades, que se dizem nessas perfeições, não podem merecer um tal nome, a não ser relativamente ao ente, qualquer seja ele, que as sente, que as apetece, ou que as contempla como apetite dos outros ou decerto apetecíveis. É forçoso dizer, portanto, que a existência da matéria insensível, a sua natureza, as suas perfeições, se não pudessem ser sentidas ou conhecidas por outros seres, jamais teriam podido receber o nome de perfeições; não seriam conhecidas como tais: aliás, privadas dessa sensibilidade deles, nem sequer seriam, justamente porque não se poderiam conceber, quando se afastasse delas a qualidade de poder ser matéria do sentimento. Portanto, as perfeições das coisas inanimadas são e se conhecem somente porque elas têm relação com a faculdade de sentir e apetecer, embora esta não esteja anexa nelas, mas lhes seja alheia, colocada em outro ser.

Por exemplo, a perfeição de uma flor ou de um fruto está na própria flor ou no fruto, mas sou $E u$, ser diverso deles, que deles apeteço e sinto-lhes o odor ou o sabor; sou eu quem forma a ideia daquele fruto ou flor, da sua natureza, das suas perfeições, daquilo que convém ou não à natureza deles. Ora, digo que a relação que aquele fruto e aquela flor têm comigo e em geral com os seres que podem receber sensações a partir deles é tão essencial que a existência daqueles seres pressupõe essa relação; nem se pode imaginar essa relação anulada, sem jogar fora e anular esses mesmos seres e até mesmo a sua própria possibilidade.

Da análise que fizemos até aqui das perfeições privadas de sensibilidade resulta que a ideia da perfeição de qualquer natureza chama e pede por um sentido, esteja ele no ser que possui a perfeição ou em outro inteiramente separado; e que é em relação a esse sentido que ela se diz e é perfeição, de modo que, se colocamos de lado a sensibilidade da perfeição, não resta nem ao menos o conceito da própria perfeição; e 
quando digo sensibilidade quero dizer a atitude que tem aquela perfeição de ser sentida e apetecida não importa por quem.

Há, portanto, uma estreitíssima e essencial relação e nexo entre a perfeição de uma natureza e o apetite da mesma; já que esse apetite sensível é condição necessária à existência daquela; e assim o bem não pode ser formado de um único elemento; mas todos os dois são requeridos para constituí-lo, sendo a perfeição e o sentido dessa termos relativos, conclusão que, por mais maravilhosa que possa parecer, é irrecusável, já que dada pela análise do conceito de perfeição, pois uma perfeição que não dá nenhum gozo, não pode ser concebida como perfeição, mas como algo de todo indiferente, que nada aperfeiçoa, porque é nada.

Mas, depois disso, juntamente com essa relação e nexo essenciais entre a perfeição das naturezas e o sentimento das mesmas, deve-se reconhecer e estabelecer também a essencial diferença entre elas: esses dois elementos estão muito unidos, quase inseparáveis, já que um chama o outro, a ideia de um compreende a do outro; mas, ao mesmo tempo, um não é o outro, antes um tem tal relação de oposição ao outro, pela qual não podem jamais mesclar-se e tornar-se o mesmo.

Verdadeiramente não se pode conceber sentido, apetite, gozo, sem uma matéria que sinta, apeteça, goze; mas o conceito dessa matéria não está de tal modo ligado ao atual sentimento dela, de modo que não possamos pensá-la como existente, ainda que fora do ato no qual é sentida e gozada, se bem que mesmo fora do ato, devemos concebê-la como em potência de vir a ser sentida e gozada, sem que seu conceito se desvaneça e nada mais dela pudéssemos pensar. No conceito da matéria do gozo (que toma o nome de perfeição) não entra a atual apetição dela, mas só sua apetibilidade, mas ela permanece distinta do ato do nosso gozo e da atual sensação agradável que dela sentimos (3).

Assim como, por um lado, a perfeição das naturezas pede um sentido e só pode ser entendida como sensível; por outro, no seu conceito há uma subsistência própria e independente, a qual age produzindo o deleite, sem receber a existência dele. Em suma, enquanto se consideram somente as perfeições próprias das diversas naturezas, sem senti-las, elas fogem da mente, não existem mais, não são mais concebíveis; ao contrário, quando são consideradas juntamente com seu efeito de deleitação, então não somente existem, mas se mostram existentes em um modo independente da sensação que a elas se refere e absoluto: admirável ligação e admirável distinção entre esses dois elementos, perfeição da natureza e sentimento da mesma, das 
quais se pode dizer que nascem coetaneamente, mas, nascendo coetaneamente, nascem com uma ordem imutável entre elas, de modo que o primeiro elemento é o gerador; o segundo, o gerado, sem, entretanto, para repetir, que um saia do outro (4).

Mas o que quero deduzir de todo esse discurso sobre as perfeições das naturezas e do gozo das mesmas? O que quero dele deduzir para responder à questão: "as perfeições são já por si sós outros bens independentemente do sentimento delas mesmas?" E, portanto: tem razão o senso comum, que vê bens também nas naturezas insensíveis e inanimadas?

Quero deduzir, em primeiro lugar, que na palavra perfeição se exprime já uma relação essencial com o gozo possível da mesma; e, no entanto, que o senso comum tem razão quando enxerga como outros tantos bens todas as perfeições das coisas, mesmo sendo essas inanimadas e insensíveis, porque essas perfeições têm todas as condições requeridas ao bem, isto é, que ele seja algo conveniente à natureza na qual se encontra, de modo que se possa dizer um mérito seu e ser algo agradável a quem o percebe, seja aquele que o percebe a própria natureza que o possui ou uma outra.

Mas quero agora inferir disso uma consequência importante acerca das diversas classes ou espécies de bens, que vimos distinguindo. Porque primeiro apontamos o bem apetecível sensivelmente por aquele que o possui; e depois, o bem que não é apetecível a quem o possui, pois quem o possui é privado do apetite sensitivo, mas é apetecível a outros seres que dispõem de sentimento. E essa consequência é que as classes indicadas do bem são diversas como é diversa a existência dos próprios seres; quer dizer, os seres são bons enquanto são. Vou explicar-me melhor.

É um certamente o modo de existir dos seres insensíveis e outro o dos seres dotados de sensibilidade. Os seres insensíveis, como já dissemos, não são em si mesmos, não se sentem e não entendem; logo não são bens em si mesmo; todas as suas perfeições são nulas em respeito a eles, porque é nulo aquilo que não se sente, nem se entende. Nem vale a pena fazer aqui suposições arbitrárias, como seria a de quem atribui qualquer sentido aos seres materiais; pois, se esses tivessem sentido, pertenceriam a uma outra classe, isto é, aos sensíveis, contra o suposto, isto é, seriam outros seres, diversos daqueles que agora são para nós, já que convém ter sempre presente que as palavras, por exemplo a palavra corpo, são impostas às coisas na medida em que as conhecemos, elas significam a essência (conhecida) da coisa e a essência é somente aquilo que se compreende na ideia da coisa. Assim, os corpos inanimados são, pela própria hipótese ou pela definição, insensíveis. Mas há mais: 
ainda que todas as coisas que conhecemos fossem sensíveis, continuaria a existir aquela distinção entre as perfeições da natureza e as sensações, existiria ademais o nó que uniria intimamente essas duas essências, que a razão enxerga inconfundíveis, ao mesmo tempo que as vê unidas, e como condição uma da outra. É, portanto, inevitável e necessário que a natureza insensível (unida ou não ao sentido individualmente) tenha uma ordem para o sentido, fornecendo a matéria para a sensação; e, na sensação e pela sensação, forneça o objeto da inteligência: nem existe de outro modo, senão como matéria do sentido e objeto da inteligência (5). Assim, ser ela matéria do sentido e objeto da inteligência entra na sua definição. Do mesmo modo em que existe a natureza sensível, as suas perfeições são bens, e são bens, por um lado, considerados relativamente (à sensibilidade), mas, por outro, considerados em si mesmos e independentemente, o que se tornará ainda mais claro, quando se formula a mesma verdade do modo seguinte.

Os seres imateriais e mais em geral as naturezas, as perfeições das naturezas, existem somente na condição de serem sentidas, seja o sentido unido a elas íntima e individualmente ou não. Isso significa que são dependentes do sentido para existir, já que sem essa relação não são nem possíveis nem concebíveis. Mas concedamos que essa condição seja verificada e admitamos que existam: elas existem então de um modo independente e absoluto; se existem verdadeiramente, existem com uma condição nova e oposta, isto é, a condição de serem independentes e de serem produtoras do próprio sentimento e, pelo sentimento, autoras do conhecimento, as agentes; e, ao contrário, o sentimento existe na condição de ser produção, efeito, paixão. Em uma palavra, há uma condição em que são possíveis (II) as perfeições da natureza e há uma condição em que são subsistentes (III). A condição em que são possíveis é aquela de uma relação com o sentimento; a condição em que são subsistentes é a de ser independentes do sentimento. Não pode causar surpresa nem parecer estranha uma semelhante oposição, pois, atentamente considerada, não se encontra somente nesse caso de que falamos, mas em muitos outros; e, aliás, é a lei, a forma universal da relação entre as subsistências e as possibilidades, entre as coisas e as ideias; ela constitui, enfim, a relação essencial, o veículo de comunicação da inteligência das coisas. Tomemos como exemplo as ideias relativas de causa e de efeito. Pode-se conceber a ideia de causa, sem se conceber ao mesmo tempo a ideia correlativa de efeito? Certamente não, o que mostra que, sob esse aspecto, a causa para ser tal depende, é condicionada ao efeito. Isso tudo, porém, na ordem das possibilidades, na ordem das ideias. Ao contrário, passando à ordem das 
coisas reais, à ordem das subsistências: encontramos a relação contrária, pois não é verdade que uma causa realmente subsistente subsiste independentemente do efeito, enquanto este é condicionado pela causa e dela dependente? A ordem ideal, portanto, tem condições diversas e mais ainda opostas à da ordem real. Mas retornemos ora ao cerne da questão. Concluo disso tudo que, apesar de as perfeições das coisas e os bens serem, em seu conceito, dependentes do sentimento, todavia eles, quando concebidos na sua real existência, se concebem como causas e não efeitos do sentimento, e por isso independentes desses seus efeitos.

Respondida a questão que foi proposta, sigamos adiante, tentando esclarecer mais a natureza do bem e aperfeiçoar sua definição.

Quando procuramos submeter à análise o conceito do bem, nossa análise recai sobre um objeto do entendimento, porque um conceito é sempre um objeto do entendimento. Procuramos, portanto, aquilo que o nosso entendimento reconhece e distingue através do conceito do bem.

Com esse fim, primeiramente deixemos de lado o que até agora encontramos, isto é: 1) que as perfeições das coisas têm sempre uma relação secreta com o apetite; 2) que elas, todavia, são costumeiramente consideradas por si só pelo entendimento, despidas dessa relação.

Devemos, portanto, fixarmo-nos nessas perfeições das coisas consideradas em si, a análise das quais deve nos dar novos resultados. Mas convém observar que pondonos a raciocinar sobre essas perfeições consideradas em si, ainda que no nosso raciocínio não caiba mais a palavra sentido ou apetite, nem por isso ela deixa de estar incluída ou subentendida, porque, sempre que dizemos perfeições, dizemos com isso mesmo quanto é necessário para constituí-la, e por isso em tal palavra está implicitamente contida a relação essencial com o sentimento, ainda que distante.

Deve-se considerar que esta é a lei do intelecto: que ele "esquece ou pelo menos não adverte mais o que ele mesmo pôs nos próprios conceitos no ato de formá-los"; e que formados esses conceitos, ele os retém num estado sintético, em que tomam em parte a natureza de uma fórmula ou cifra daquilo que a princípio se viu e a que ele se refere assim geralmente, sem lhes prestar determinadamente atenção. Um exemplo claríssimo desse modo de proceder do nosso entendimento é o processo dos cálculos algébricos, nos quais, feita a denominação e estabelecida a primeira equação de acordo com as condições do problema, essas condições se põem de lado e sem ter mais em mente a linha do raciocínio, basta realizar corretamente cada operação, segundo as 
regras particulares e nada mais, e se tem todavia no fim um resultado verdadeiro, por que se mantiveram sempre os sinais do raciocínio, a partir dos quais se pode, querendo, retornar ao próprio raciocínio explícito e manifesto (6).

Do mesmo modo, se procurarmos a origem das nossas ideias das perfeições das coisas, veremos 1) que a princípio associávamos a essas a sensação agradável, conhecendo perfeição somente onde seguia a grata impressão em nós ou pensávamos que devesse seguir ou em nós ou em outro ser sensível; 2) que depois nos habituamos a atribuir o conceito de perfeição àquelas coisas que experimentávamos gratamente, sem todavia pensar mais na sua atitude de modificar a nós ou a outrem agradavelmente, vindo assim a tomar a palavra perfeição como algo em si mesmo, independentemente do sentido segundo o qual era a princípio ordenada.

O entendimento, depois disso, foi adiante. Primeiramente, observou que, no corpo humano, o estado agradável ou doloroso correspondia a uma certa disposição das partes, a um certo ordenamento na medida, na forma, no número, na união e ação recíproca dessas partes (7): essa ordem, à qual respondia a sensação agradável atual ou habitual, foi, portanto, considerada como perfeição do corpo humano: ainda nesse caso, chamou-se perfeição àquele estado do corpo pela sua coexistência com o sentimento agradável. O homem, depois, fez uma observação similar sobre todos os outros seres semelhantes a ele, enquanto seres animados e sensíveis, e os enxergou como tão perfeitos, quando todos os seus membros e cada parte deles apresentasse aquela ordem, que parecia neles produzir a mais agradável existência. Em terceiro lugar, viu que os objetos exteriores da natureza inanimada também eram mais ou menos aptos a atender suas necessidades ou às necessidades de outros seres sensíveis, conforme esses tivessem também um certo estado, uma certa configuração e composição, e nessa sua formação útil e agradável reconheceu sua perfeição.

Ora, em todos esses casos, a palavra perfeição significa uma ordem intrínseca à natureza, à qual corresponde o estado por ela mais apetecido e ansiado. Mas como, pois, chegamos a conhecer tal ordem? A ordem, como tal, não tem uma existência por si própria, não tem uma existência nem só para o sentimento (pois o sentimento, agradável ou doloroso, é um fato simples, seja qual for o modo misterioso pelo qual é produzido e qual o número dos elementos que o produzem). A ordem só existe ao entendimento. Não se quer dizer com isso que a ordem seja algo além do ato do entendimento que a intui; mas dela pode-se dizer o que anteriormente eu disse da matéria do sentimento e do sentimento: um não pode estar por si só ou sem o outro; ambos estão juntos, embora 
não se confundam: são correlativos; diversos, têm existência simultânea no conceito da mente.

Inicialmente, como dizíamos, na primeira formação de nossos conceitos, extraímos aquela ordem intrínseca, na qual colocamos a perfeição dos entes, da sua atitude para produzir em si ou em nós ou a quem quer que seja um constante sentimento agradável, de modo que essa atitude é originalmente a base, a regra, o princípio daquela ordem. Mas depois disso formamos conceitos mais especiais sobre as perfeições das coisas, porque seria muito difícil dever recorrer, cada vez que queremos medir-lhes a perfeição, ao último princípio, aquele da relação que têm de agradar os seres sensíveis. Com esse fim, portanto, compomos para todas as coisas o conceito de sua ordem intrínseca, que tomamos por tipo ou critério próximo, segundo o qual julgar os graus de sua bondade, aliás, nessa ordem frequentemente tomamos a própria essência, a espécie da coisa (8).

Mas depois, compostas essas espécies ou essências que supõem uma ordem (ordem que na origem principiou com ação ou com seu efeito sobre a sensibilidade), o entendimento, digo novamente, para nisso e, sem prestar mais atenção à relação com os entes sensíveis, se deleita daquela ordem, como se fosse boa ou bela em si mesma: considera-a não no seu fim, mas nas forças que a fazem ser, que a conservam, que a aumentam e desenvolvem até a realização da essência inteira. Esse modo de considerar o ente se refere, portanto, ao seu modo e ordem intrínsecos e nisso se habitua o entendimento a reconhecer um bem (9).

O senso comum é verdadeiro quando mostra acreditar que a inteligência aprova como bem o que convém à natureza da coisa ou o que se harmoniza com o princípio da sua existência. Pois é evidente que aquilo que repugna ao princípio da existência da natureza é reprovado e considerado como um mal, cuja visão causa uma grande moléstia ao ente que o contempla: em uma palavra, tudo que tende a destruir uma natureza é considerado como contrário àquela natureza, como seu inimigo, como o seu mal; e nessa contrariedade do elemento do qual se fala com a natureza que a possui, nessa desarmonia, nessa desordem, está seguramente o que a razão desaprova, como eu dizia, já que essa desaprovação é somente o perceber que há algo em um ser que está em contradição com a sua essência, a qual se torna a regra de seu bem e do seu mal; quer dizer, tudo que é requisitado por sua essência, que o desenvolve, o completa, em vez de destruí-lo, é o bem desse ser; o que luta com sua essência, que está em contradição com ela, impede seu pleno desenvolvimento, é certamente o seu mal; e é 
naquela essência que, originalmente, escondia-se uma relação com uma sensibilidade, relação que depois é esquecida.

Sobre isso, creio, não pode haver motivo de dúvida; e entendo que essa exposição do mal e do bem não se afasta das ideias comuns dos sábios e direi também que nem exceda aquele grau de reflexão que a maioria dos homens possui e com o qual operam ao analisar ou reconhecer as próprias ideias. Resumindo, portanto, o que dissemos em outra ordem:

1) Existem os entes reais, cada um dos quais pode se encontrar em uma série de estados diversos.

2) Um desses estados é escolhido como o perfeito pelo entendimento humano e como tipo de perfeição, isso mediante a relação com a sensibilidade.

3) Nesse estado-tipo há uma ordem, que o intelecto divisa e na qual encontra o bem.

4) Essa ordem começa com a existência e com a essência da coisa, aos quais se sobrepõem aqueles outros elementos que colocam a coisa no já mencionado estado de perfeição.

Para essas coisas, pode-se dizer que todos os constitutivos de uma natureza têm um só fim (estado perfeito, típico), ao qual tendem incessantemente todos, todas as forças daquela natureza, cujo fim é, pois, a essência completa dessa natureza (10); e que esse fim simples é de sua natureza e não por outra razão extrínseca, em contradição ou harmonia com certas modificações que a coisa recebe. É possível aprofundar-se além disso com o pensamento e considerar a própria ordem essencial e necessária do ser, isto é, a ordem que, sendo intrínseca ao ser, vai excluir certas coisas das naturezas e admitir e chamar certas outras, por uma necessidade intrínseca, que se extrai e se contempla intuitivamente no primeiro fato, ou seja, no próprio ser, objeto primitivo de todo pensamento: já que finalmente todas as essências das coisas são somente o ser mais determinado e limitado, o ser mais em ato; determinações, limitações e atos que têm sua origem, como também sua causa única, a sua necessidade, no próprio ser, que nesses diversos modos se determina, se limita e se atua, e não o contrário. E é de todas essas reflexões finalmente que se pode chegar a uma definição do bem suficientemente determinada para o uso que devemos dela fazer: eis como ela resulta das coisas ditas até aqui.

As perfeições, os méritos das coisas, são sinônimos de bem, e se concebem certamente como causa do sentimento agradável, mas a mente as contempla também 
independentemente desse seu efeito, como algo de real, de objetivo, de ativo; e, portanto, o bem é mais geral que as sensações, é anterior a elas, embora seja causa delas e relativo a elas.

As coisas têm as suas perfeições, os seus méritos ou bens, da mesma maneira que têm o ser: por tal modo, as coisas que têm uma existência somente material, como aquelas privadas de sentimento, têm igualmente perfeições, bens relativos àqueles seres que as percebem.

Esses méritos e bens das coisas são tudo isso que as harmoniza com a perfeita existência delas, tudo isso que, numa coisa, tende a lhe dar a plenitude de seu ser, do qual a sua essência (abstrata) é, quase queria dizer, o tema: tudo isso a que as forças da própria coisa se voltam como fim do seu movimento. Ao contrário, tudo o que está em oposição ao ser da coisa, que nega a coisa, que tira tudo quanto lhe seria necessário ou conveniente, quanto ela com a sua atividade interior tenta conseguir, chama-se o mal da coisa.

Assim como a essência abstrata é o princípio da ordem, a essência completa é seu fim. Entre a essência abstrata e a essência completa de cada coisa, há uma gradação de perfeição e de bem.

A essência completa e típica se deduz da relação da coisa com a sensibilidade.

Mas essa relação, e a ordem consequente, só existe pelo intelecto em um ser intelectivo, que tem por isso a noção de bem.

Que consequências queremos extrair das noções de bem e mal assim desenvolvidas?

Em primeiro lugar, que em cada coisa pode haver uma série de bens, começando da sua primeira e mais imperfeita existência, e prosseguindo ao seu último desenvolvimento e cumprimento.

Em segundo lugar, que todos esses acréscimos à coisa, todas essas adições, que vão completá-la e torná-la mais plena, não são senão outros tantos atos do seu ser, outros tantos graus da sua entidade. De modo que se pode concluir razoavelmente com a máxima de toda a antiguidade: toda coisa é boa enquanto é e, enquanto não é, é má.

O bem, portanto, é igual ao ser; o bem é o próprio ser; o ser se realiza, se atualiza, se desenvolve: no atualizar-se, no desenvolver-se, tem uma ordem intrínseca e necessária, da qual se pode encontrar a razão somente nele mesmo. Essa ordem faz, sim, com que uma coisa peça ou exclua uma outra; como uma raiz pede um tronco, o tronco pede os galhos; os galhos, as flores e os frutos: com estes finalmente a árvore se 
completa. Quando uma coisa pede uma outra pela ordem intrínseca do seu ser, essa outra lhe é boa; quando a exclui, lhe é má. A própria sensibilidade só entra no bem porque ela mesma pertence ao ser, ela mesma é um ato do ser. É a natureza do ser que exige uma relação entre a matéria e a sensibilidade, para que haja o bem. O mesmo se diga do entendimento, também um ato do ser. Ser e bem são, portanto, o mesmo, apenas que o bem é o ser considerado na sua ordem, a qual é conhecida pela inteligência, que, conhecendo-a, dela se deleita: o bem, em uma palavra, "é o ser sentido em relação com a inteligência", enquanto essa vê aquilo que toda natureza exige de si mesma, aquilo a que tende com suas forças do modo já mencionado.

Finalmente, devo confirmar com a autoridade da razão alheia a minha doutrina sobre o bem, o que farei não citando um ou outro nome de filósofos, mas uma máxima comum das escolas cristãs, das quais não pode haver testemunho mais seguro do que o de São Tomás, que, na Suma Teológica, prometeu reunir e sintetizar as doutrinas espalhadas nos monumentos de toda a tradição eclesiástica, e, pelo consenso universal, cumpriu a promessa. Assim diz ele à nossa necessidade: "O bem e o ente são quanto à coisa; mas diferem quanto ao conceito: pois o conceito do bem consiste nisto: em que a coisa seja apetecível; ora é claro que qualquer coisa se apetece enquanto é perfeita, pois todas as coisas apetecem a própria perfeição. Desse modo, pois, toda coisa é perfeita enquanto tem o ato de ser, do que se evidencia que uma coisa é um bem na medida em que é um ente, pois o ser é a atualidade de toda coisa" (11). 


\section{$\underline{\text { Notas }}$}

(I) N.T. Apetece/apetecer Cf. glossário, pág. 213

(1) N.A. Como o sentido exibe ao entendimento as coisas a perceber é algo que já discutimos amiudadamente na Ideologia. Vejam-se também os Opuscoli filosofici, vol. I, pp. 59 e segs.

(2) N.A. Essa observação me parece de suma importância e não é tão fácil de ser expressa. Somos dotados de sentido; logo estamos inclinados a dar sentido também às coisas inanimadas, assim como também estamos inclinados a formar ideia das coisas com base na ideia que temos de nós mesmos. Mesmo quando não damos expressa e diretamente sentido às coisas inanimadas, tendemos a considerá-las coisas em si mesmas, embora sua existência seja meramente relativa a quem a sente, ou a quem a contempla como sentida. É extremamente difícil fazer ideia do que são as coisas inanimadas relativamente a si ou ainda destruir essa ideia que dela formamos vaga e falsamente com a imaginação. Mas devemos destruir por completo essa ideia imaginária e, para fazê-lo, imaginemos que cessasse em nós mesmos todo pensamento e todo sentimento: com isso teríamos eliminado a ideia de nós mesmos, anulado nós mesmos em nós mesmos. Ora, esse nada, nas coisas insensíveis, é de fato e devemos também colocá-lo de direito em nossa imaginação, para não ficarmos com uma ideia quimérica fonte de imprecisões e infinitos erros. Em tal caso restará das coisas inanimadas somente a existência objetiva, inteiramente relativa ao ser ao qual elas são objeto ou, pelo menos, termo de ação. Alguns filósofos observaram essa existência puramente relativa das coisas materiais e ou lhes negaram propriamente uma existência, como Platão, ou tentaram incorporá-las no espírito, como os idealistas ou os transcendentais da escola germânica. No meu sistema não se vai além da observação. Limitamo-nos a afirmar o fato de que "existe uma força que nos modifica, produzindonos sensações e é nesse sentido que afirmamos sua existência”. Essa força é o corpo, que é para nós uma substância, ao passo que a primeira ideia que temos do corpo vem dele; isto é, o corpo se concebe sem necessidade de outro ser a que adira, característica que marca as substâncias subordinadas e criadas.

(3) N.A. Não é necessário que eu me ponha, aqui, a buscar a razão pela qual, mesmo no fenômeno da sensação, concebemos uma matéria distinta e independente da própria sensação. Quem conhece a doutrina acerca das sensações por mim exposta no Nuovo saggio, poderá empreender por conta própria essa sutil e importante investigação, e 
verá que permanece em nossa mente o conceito de uma matéria da sensação, distinta da própria sensação, por causa da dupla maneira de sentir, subjetiva e extrassubjetiva, e porque, nessa última, as sensações que se produzem identicamente segundo leis determinadas, as quais fazem supor um agente, do qual conhecemos apenas a potência que tem de modificá-las sensivelmente.

(4) N.A. Em todos aqueles chamados seres mentais se encontra essa conjunção e separação, essa ordem de oposição que têm entre si: as coisas possíveis (as ideias) com certeza não existem fora da mente; é impossível concebê-las como existentes sem uma inteligência que as contenha, assim como é impossível conceber uma inteligência sem ideias. Não obstante, embora essas duas essências nasçam imediata e contemporaneamente com a sua conjunção num indivíduo, todavia nascem com uma ordem entre elas, de modo que as coisas possíveis tornam-se independentes, absolutas, necessárias, eternas e ativas; a mente nasce de um modo passivo e como efeito daquelas, porquanto se trate de uma mente que pertence a um sujeito contingente, mutável, enganoso. Ver Nuovo saggio, vol. 3, págs. 315 e segs.

(5) N.A. A distinção entre a matéria do sentido e o objeto da inteligência é explicada no Nuovo Sagio, vol. 2, págs. 60 e segs.

(II) N.T. Possíveis: Cf. Glossário, pág. 214.

(III) N.T. Subsistentes: Cf. Glossário pág. 214.

(6) N.A. Dessa observação nasce o nominalismo, uma vez que todo erro se origina em alguma verdade da qual se faz mau uso. $\mathrm{O}$ erro dos nominalistas é considerar que o intelecto não poderia fazer uso de números, se a esses números não se atribuísse sempre um valor geral. O que se esquece no uso dos números é somente seu valor particular e determinado. Quando raciocinamos usando números, sempre retemos as relações e os dados que nos permitem indicar seu valor determinado. Esses dados e relações constituem o valor geral dos números. Evidentemente, essa observação, longe de favorecer o nominalismo, antes lhe retira a base. $\mathrm{O}$ valor geral que determina os números é precisamente um conceito universal. Por conseguinte, um número não é somente um sinal significando nada. Ao contrário é um sinal ou número apenas quando realmente se refere a um pensamento universal. Assim, ele pressupõe os universais sem explicá-los.

(7) N.A. Como o homem percebeu essa ordem? Principalmente com o modo de sentir extrassubjetivo. Essa correspondência do sentimento e da perfeição resolve-se então numa igual correspondência entre os dois modos de sentir subjetivo e extrassubjetivo. 
Lamento observar que essa importantíssima distinção desses dois modos de sentir não foi ainda percebida entre aqueles que se aplicaram ao estudo da nossa filosofia. No entanto, ela é a chave que possibilita a entrada na doutrina que propusemos.

(8) N.A. A seguinte observação servirá como prova de que formamos originalmente esse tipo da ordem intrínseca das coisas a partir da relação que elas têm com nossas sensações de prazer. Qualquer ente natural sujeito à lei do desenvolvimento passa por estágios sucessivos, em cada qual ele é perfeito, pois é o que é e nem deve ser diferente do que é. Ora, entre todos esses estados possíveis do ente, nós escolhemos um em que estabelecemos que o ente tenha assumido sua última perfeição. Nessa escolha, que princípio nos guia? O de nossas necessidades e satisfação, como dizíamos: dizemos perfeito o ente que atingiu o estado que nos é mais útil. Nas árvores frutíferas estabelecemos que o estágio mais perfeito é aquele em que têm as frutas maduras, e não aquele em que elas florescem; ao contrário, quanto às árvores cujo fruto ou semente em nada nos serve e as flores nos deleitam, o estágio perfeito é o do florescimento. Assim, nós as chamamos de árvores floríferas, o que mostra que colocamos a sua essência em dar flores, cujo cheiro nos agrada, enquanto os frutos nos são indiferentes.

(9) N.A. Entre a ordem do ser considerada em si e a ordem do ser relativa à sensibilidade, há uma admirável e profunda harmonia. Uma investigação tão importante e difícil convém entrar na agatologia $(*)$, da qual resulta serem inseparáveis o ente e a sabedoria, um não podendo ser pensado sem a outra. Aqui, posso somente fazer um aceno a isso. Observarei ainda que o entendimento, já habituado a considerar a perfeição das coisas na ordem do ser, às vezes cria entes e ordens arbitrárias e hipotéticas, que só podem ter uma perfeição também arbitrária e hipotética. Essas criações da mente humana não constituem, contudo, uma objeção à doutrina que apresentamos, de que o bem se refira sempre a algumas faculdades do sentir e do desejar.

(10) N.A. Ver o que é a essência completa no Nuovo saggio, vol. 2, págs. 201 e segs.

(11) N.A. "Suma Teológica", I q.5-1.

(*) N.T. Por "agatologia", entenda-se o estudo do bem, cf. os tópicos "ideologia" e “eudemonologia”, no Glossário, respectivamente, às págs. 211 e 214. 


\section{Artigo II}

\section{O que é o mal}

Se bem que tudo o que se disse até aqui também tenha servido para expor a noção de mal, assim como a do bem, será útil acrescentar a observação que segue sobre a natureza do mal.

Vimos que em todos os constituintes possíveis de qualquer ser há uma ordem, de tal modo que esses constituintes são determinados e distintos de todos os outros, isto é, para toda natureza há uma classe de qualidades e de condições que convém e outras que são estranhas ou mesmo contrárias a ela. Ademais, essas entidades que convêm, esses constituintes possíveis de um ser, são mais ou menos necessários, mais ou menos convenientes ao próprio ser que constituem: têm o caráter de bem para ele, em razão dessas suas mais ou menos iminentes exigências. Ora, portanto, se o bem, assim como o mal, implicam em si uma relação com o princípio daquele ser que afetam, isto é, com a essência daquele ser, eles consistem em uma relação de harmonia ou desarmonia com aquele ser, de modo que tanto o bem quanto o mal, para existirem, pressupõem o sujeito a que se referem. Digo tanto o bem quanto o mal, pois, ainda que não se possa duvidar que o bem exija o ser, na medida em que ele é finalmente o próprio ser, todavia seria possível pensar diversamente em relação ao mal; seria possível crer que ele não pressupusesse o bem, já que é uma negação, ou seja, uma carência.

Convém, no entanto, observar que, embora cada coisa seja um bem enquanto é, enquanto tem o ser, nem por isso se pode dizer que uma negação plena do ser seja um mal, pois de uma negação plena resta só o nada; e o nada é nada, logo, não é mal nem bem. Contudo, o mal envolve, como já disse, uma relação com o ser, com o sujeito que o tem em si. O mal é sim, portanto, uma negação, não de todo o ser, mas de alguma parte dele, de algo de que o ser necessita e lhe falta; do que decorre observar-se uma repugnância entre o princípio daquele ser e essa falta. Assim, um corpo humano a que faltassem os braços ou as pernas sofreria um mal, porque lhe faltaria uma parte integrante, uma parte que pela essência do homem é demandada e pela ordem intrínseca desse ser homem querida, do que decorre que, vendo-a faltar, a inteligência encontra uma imperfeição naquela natureza, uma coisa oposta à sua ordem intrínseca e imutável. Justamente por isso empregava-se a palavra privação, em vez de negação, para designar o mal, já que esta última é excessivamente geral e vaga, exprimindo tanto a remoção do todo, quanto a da parte; ao passo que a palavra privação exprime a remoção 
de parte e não de todo o ser, e inclui a ideia de um ser que permanece privado de algo, mas que nem por isso foi absolutamente reduzido a nada. 


\section{Artigo III}

\section{Como a ideia do ser é a noção com a qual se julga o bem em geral}

Se portanto o ser e o bem são uma mesma coisa; se cada natureza é boa enquanto é, ao passo que é má enquanto lhe falta alguma parte do ser que lhe convém; se o ser de cada natureza tem em si uma ordem intrínseca, que determina a necessidade de certas partes, de certas qualidades, as quais se tornam por isso os bens, as perfeições daquela natureza, como a análise do que entendem os homens pela palavra bem demonstra; então, segue facilmente essa consequência: que conhecerei o bem, o mérito, o grau de perfeição de qualquer natureza, quando conhecer o seu ser, quando souber quais graus possui da existência que lhe cabe; isto é, quando me for conhecida a ordem que tem em si o ser daquela natureza, e que se expressa em sua essência e se compreende na ideia da mesma, sendo tanto mais expressamente compreendido, quanto mais a ideia é perfeita; e quando também me for conhecido o quanto essa ordem do ser se realizou e desenvolveu, seja plenamente, ou carente, truncada e impedida em seu cumprimento. Portanto, o conhecimento do ser, do modo, da ordem do ser de uma coisa é também o conhecimento de sua bondade: de modo que com uma só noção, aquela do ser, meço e constato a um só tempo os graus de existência real que tem a coisa e os graus de sua perfeição, pela coincidência dessas coisas em uma só.

E verdadeiramente, se o ser e o bem são o mesmo, convém que sejam os mesmos o conhecimento do ser e do bem (12), não tendo eu que fazer outra coisa do que considerar o ser em sua ordem intrínseca, para que ele adquira e receba o nome de bem.

Fica então evidente, depois disso, que a ideia do ser é aquela noção, aquela regra, aquele princípio, com o qual eu meço e identifico o bem de todas as várias naturezas que percebo e conheço. 


\section{$\underline{\text { Nota }}$}

12) N.A. Sendo o mesmo a ideia do ser e a do bem, fica clara a verdade do que disse Platão: "na ideia do bem está a disciplina máxima" - A República, livro VI, cap. 16, $505 \mathrm{a}$. 


\section{Capítulo III}

\section{A ideia do ser considerada como o princípio da eudemonologia \\ Artigo I}

Definição da ciência eudemonológica

A ciência eudemonológica é aquela que ensina a formar a própria felicidade.

Distingo a ciência da felicidade e a da moral (I), chamando aquela de eudemonologia (II) e essa de ética ou moral, ciências que sempre são mais ou menos confundidas ou, a meu ver, não muito claramente distintas. Uma escola moderna (III) chegou a tornar sistemática a confusão de uma dessas duas ciências com a outra, confusão e mistura que nasce sempre em prejuízo, aliás, destruição completa da moral: desta ciência, honra da humanidade, que eleva o homem acima de seu próprio interesse, acima si mesmo, e que existe somente com a condição de esquecer o que é útil a si mesmo e ocupar-se apenas do justo e do honesto.

Não obstante, devemos render aqui um tributo de louvor à escola germânica (IV), que liberou a moral do estímulo à felicidade. Se depois tivesse sido bem-sucedida em determinar a verdadeira natureza da própria moral; e não se tivesse parado em um estímulo do bem moral, privado dos caracteres necessários para ser moral, em um discurso último (1), fatal, cego e por isso irracional, por nada justificado, mas imposto ao homem por uma lei de natureza férrea e cruel; ela teria tido a glória de dar à moral uma forma científica e de ditar com segurança o seu fundamento. 


\section{$\underline{\text { Notas }}$}

(I) N.T. A distinção é um dos aspectos a ser destacado da obra de Rosmini. Vale lembrar que as éticas da Antiguidade assumem a felicidade (eudemonia) como princípio da vida moral. São eudemonistas, nesse sentido, a ética de Aristóteles, a dos estoicos e dos neoplatônicos, assim como, na Era Moderna, a ética do empirismo e do Iluminismo. Kant, por outro lado, vê o eudemonismo como o ponto de vista do egoísmo moral, da doutrina "de quem restringe todos os fins a si mesmo e nada vê de útil fora do que lhe interessa" (Antropologia do ponto de vista pragmático, I, § 2).

(II) Eudemonologia: Cf. Glossário, pág. 214.

(III) N.T. A referência é ao sensismo, tal qual formulado por Condillac, no Traité des sensations (1754), que retoma muitas das formulações da filosofia de Locke, eliminando seus aspectos propriamente psicológicos e enfatizando como as faculdades cognoscitivas se desenvolvem da ação dos sentidos.

(IV) N.T. A referência é a Kant, pelos motivos apresentados na nota (1), que segue.

(1) N.A. Até os bons e retos escritores da Alemanha incorrem, sem disso se aperceber, nesse erro. Muitos deles começam seus tratados morais estabelecendo, no homem, dois estímulos últimos: a felicidade e a honestidade. São eles o fato primeiro de que partem, mas isso não pode de jeito nenhum bastar à moral, que não deve descender de um estímulo; ela não é um instinto, pois, se fosse, não seria obrigatória. A obrigação é algo que se opõe ao instinto, é algo que dirige todos os instintos e força o homem a admitir a sua direção. Se a moral fosse um mero estímulo, não seria racional. O caráter da moral é a racionalidade, que não é um estímulo ou um instinto. Deve-se, portanto, encontrar o princípio da lei moral na razão e não num estímulo primitivo. 


\section{Artigo II}

\section{A ideia do ser e o princípio da eudemonologia}

Tendo visto que a ideia do ser é o princípio com o qual se julga o bem em geral, vimos também que ela deve ser o princípio que nos permite conhecer o que é bem ou mal, o que convém ou não convém a nós mesmos. Trata-se, portanto, do princípio supremo dessa ciência que versa sobre a felicidade.

Entretanto, embora essa ideia seja o princípio supremo, a régua com que podemos medir o nosso próprio bem, os graus de nossa felicidade; por outro lado é manifesto que ela não pode ser o princípio próprio dessa ciência, mas um princípio comum a muitas outras. Já que essa ciência não trata de todo o bem, mas do meu próprio bem, de um bem subjetivo, em uma palavra; então a ideia do ser é um princípio extremamente amplo que não precisa ser próprio e exclusivo da eudemonologia, como aquele que é a ideia do bem em geral; e a ciência da felicidade usa de uma noção mais particular, isto é, a do bem subjetivo e humano, da qual se ocupa. Por isso, não será inútil que acrescentemos aqui algumas palavras sobre o bem subjetivo e próprio do homem, de modo que esse não se confunda com o bem em si mesmo. 


\section{Artigo III}

\section{O que é o bem subjetivo}

Quando considerado em relação a um sujeito que dele goza, o bem se chama subjetivo, uma vez que o bem em si mesmo e visto de modo absoluto não pode ser considerado relativamente a ninguém.

Aliás, para que qualquer coisa, que é um bem em si, possa também ser um bem para um sujeito qualquer, é necessária uma conveniência particular daquele bem àquele sujeito, ou, melhor dizendo, daquele sujeito àquele bem. Vale dizer que é necessário que a natureza do sujeito seja tal, que ele possa ajustar-se e se unir devidamente àquele bem de que se trata e com ele formar quase uma única coisa, união de que advém o gozo daquele bem pelo sujeito; e, no entanto, com muita frequência, ocorre que, pela inaptidão do sujeito a se unir convenientemente às coisas e delas fruir, estas, mesmo sendo boas em si, não são um bem para ele, mas ou lhe são indiferentes ou ainda más. Daqui a razão pela qual o bem sensível é um nada para as naturezas insensíveis, porque essas, enquanto privadas de sentido, não têm a potência de aplicar a si os bens sensíveis, nem de se unir a eles ou deles fruir; igualmente, é um nada a virtude, a sabedoria e outros bens suprassensíveis aos animais, que não têm razão nem intelecto, pois esses bens se percebem e se gozam somente com essas faculdades que eles não possuem; eis porque a sabedoria e a virtude são os sumos bens daqueles seres que possuem as potências do intelecto e da vontade, para os quais, somente, como veremos, existe o bem absoluto.

Portanto, apesar de toda coisa ser boa em si mesma, todavia nem toda coisa é necessariamente boa para qualquer sujeito: há coisas que, para alguns sujeitos, nem sequer existem e também aquelas que são nocivas e más para certos sujeitos, mas são boas para outros. Como os homens costumam olhar o bem subjetivamente e em relação a si, e não objetivamente ou em si mesmo, daí decorre que muitos haja que perdem inteiramente de vista o bem em seu próprio conceito objetivo e o negam de todo, declarando ser também um paradoxo (não sem desprezo por aqueles que o sustentam) o dizer que toda coisa é boa ou o dizer que toda coisa é boa enquanto é. Pois, observam estes, todos os seres não lhes são bens, a eles ou aos homens; e disso concluem que todos os seres não são bens, discurso que seria verdadeiro somente quando se referisse ao bem subjetivo, ou seja, relativo, mas é falso raciocinando-se sobre o bem em geral. E se estes, que são muitos, os quais não conseguem se elevar acima dos bens relativos nem sair de si mesmos, pudessem, porém, considerar atentamente que não existe 
nenhum ser ou perfeição de ser, que não seja bem para algum sujeito, ou não seja bem para si mesmo, perceberiam muito facilmente que em cada ser, não importa qual, existem as condições do bem, dado que as condições pelas quais se dizem as coisas boas, são que elas sejam boas em si mesmas, que sejam completas, que tendam com as forças próprias de sua natureza à própria conservação e perfeição (2).

Daqui advém que os antigos definissem o bem como "aquilo que apetece todos os seres" (quod omnia appetunt), tomando a palavra apetecer num sentido amplíssimo, como observei, para indicar qualquer tendência das forças de uma natureza. Porque cada ser, como eu dizia, mostra nesse sentido apetecer a si mesmo, quer dizer, ter em si uma força que o faz existir, conservar-se, aperfeiçoar-se. Consideravam aqueles sutis investigadores da sabedoria o bem em seu conceito próprio e descobriam que o conceito próprio de bem consistia no apetite, ou tendência das coisas em direção a elas mesmas, e não já no ser apetecido, amado, atraído, como se quiser, por outras coisas diferentes delas mesmas, atração que somente demonstra que uma coisa é boa para outra, não que é boa para si mesma e constitui o conceito do bem relativo, não simplesmente do bem.

O conceito e a razão do bem, tomados simples e puramente, são comuns a todos os seres e a todos os graus dos seres; e, por isso, convenientemente se diz que cada ente é um bem enquanto precisamente ele é. Não se confunda, portanto, a noção do bem em si mesmo, com a noção do bem relativo, pois uma coisa é ser bem para si mesmo e, assim, em si mesmo, outra coisa bem para outrem. O ser bem para si mesmo é o que constitui a simples noção do bem; o ser bem para outrem é o que constitui a noção relativa do bem. E disso, de uma coisa ser boa para outra, não se pode extrair a consequência de que ela seja boa, mas apenas que tenha uma relação de bondade; por isso, ela é boa somente segundo aquela particular referência, e não no seu todo, no seu ser; é boa no efeito que produz em uma coisa diversa de si: mas em si, onde nada mais houvesse, em vez de verdadeira e atualmente boa, não se poderia dizer senão que fosse boa em potência, ou seja, que tivesse a potência de fazer algum bem. 


\section{$\underline{\text { Nota }}$}

(2) N.A. Os próprios seres inanimados reagem à sua destruição com as forças de que dispõem, isto é, com as quais subsistem. Isso é tão intrínseco e necessário a toda natureza, que dizer que uma natureza é já é dizer que ela sustenta um esforço contínuo à sua própria existência e assim lhe repugna continuamente seu aniquilamento. Todavia, esse caráter intrínseco e necessário que dá a todas as coisas a noção de bem em si mesmas é bastante imperfeito, como já o dissemos, nas naturezas inanimadas, assim como é imperfeito o seu ser, que elas não sentem e nem percebem. São, portanto, um bem em sentido relativo e dependente, e não em sentido próprio e verdadeiro. 


\section{Artigo IV}

\section{Princípio próprio da eudemonologia}

A eudemonologia trata da felicidade humana.

A felicidade humana é um bem subjetivo, do qual acima fizemos a descrição. Mas não basta ter encontrado o que é o bem subjetivo em geral para poder dizer que bem se conhece aquela noção que deve servir de princípio próprio à ciência de que falamos.

A felicidade humana é um bem subjetivo específico, um bem subjetivo próprio do ser inteligente: a noção, portanto, desse bem específico é o que deve formar o princípio próprio da eudemonologia.

Não tínhamos o intuito de expor neste livro os princípios da ciência eudemonológica, mas os da ciência moral. Todavia foi necessário falar da eudemonológica para evitar o perigo de confundi-la com a moral, o que se fez e se faz com muita frequência em nossos tempos. E pelo estreitíssimo nexo que há entre felicidade e justiça, considero útil e até necessário pedir licença ao meu leitor para acrescentar algumas palavras acerca da noção de felicidade, que é o supremo e mais perfeito bem do homem.

Com esse fim, começarei por distinguir o bem de existência do bem de aperfeiçoamento. 


\section{Artigo V}

\section{O que é o bem de existência e o que é o bem de perfeição}

A primeira coisa que concebemos com a mente num sujeito qualquer é a existência; depois, a perfeição.

Há algo em cada sujeito sem o que ele não pode existir, e isso se costuma chamar sua substância ou essência específica (3). Há também outras coisas sem as quais aquele sujeito pode existir com certeza, ainda que imperfeitamente, sendo essas as suas perfeições acidentais. Ora, quando essas perfeições acidentais se sobrepõem à essência específica do sujeito, então este se finaliza e completa, porque essas perfeições são precisamente atos e desenvolvimentos maiores do ato de seu ser e, portanto, outros graus do ser que ele adquire.

Como, portanto, o ser se divide em substancial e acidental, assim convém que se divida igualmente o bem em substancial e acidental: consequência dos princípios postos, isto é, daquela verdade fundamental que estabelecemos, que o ser e o bem não diferem entre si, senão pela maneira diversa como se olha a mesma coisa.

Todavia, nenhum sujeito pode apetecer, ou seja, tender à existência, antes que a possua, dado que nenhuma coisa pode fazer o que quer seja sem antes existir ela mesma.

Mas, quando começa a existir, então um sujeito pode demonstrar a tendência que tem de se desenvolver e de se aperfeiçoar ainda mais, bem como de preservar-se, caso sua existência seja atacada. E é essa dupla tendência, que o volta para a própria conservação e o próprio desenvolvimento e aperfeiçoamento, que indica uma dupla espécie de bem, que queremos aqui distinguir, isto é, o bem de existência e o de perfeição.

O fim último, porém, ao qual se voltam e tendem incessantemente todas as forças de um sujeito qualquer é o aperfeiçoamento de si mesmo, e é esse o fim último do apetite ou, para falar de modo mais geral, da tendência de cada natureza, que sói receber o nome de bem, assim como observa São Tomás, de quem são estas palavras: "bem se diz de qualquer coisa respectivamente à perfeição, que é o objeto do apetite e, por conseguinte, o bem tem em si mesmo o conceito de último" (isto é de último fim do apetite, ou ainda último fim da coisa). "Porque isso que é ultimamente perfeito se sói chamar bem, simples e puramente; daí que o que não tem a perfeição última que deveria ter não se convém chamar perfeito simplesmente, nem bem, mesmo que possua alguma perfeição, aquela de existir, mas onde se diz bem, diz-se isso em um sentido 
particular. Assim, quanto ao ser primeiro, ou seja, ao ser substancial, uma coisa se chama ente simplesmente, e bem respectivamente, ou só naquele sentido, que é; enquanto ao último ato do ser mesmo, isto é, à perfeição, uma coisa se diz ente respectivamente e bem simplesmente" (4).

Ora, assim como distinguimos o bem de existência e o bem de perfeição, também podemos distinguir igualmente o mal de destruição e o mal de deterioração. 


\section{Notas}

(3) N.A. Convém ver a doutrina em torno da essência no Nuovo saggio, vol. 2, págs. 201 e segs.

(4) N.A. Tomás de Aquino, Suma Teológica, I, q.5, a 1, ad primum. 


\section{Artigo VI}

\section{O que é o mal de destruição e o mal de deterioração}

O nada não é mal, como vimos. Todavia, pode-se distinguir um mal de destruição e um de deterioração. Eis como se concebem estas duas espécies de mal:

Sempre que uma causa, qualquer seja, age sobre algum sujeito de modo a diminuir algum grau de seu ser, essa causa é nociva àquele sujeito.

$\mathrm{Na}$ ação que tal causa exerce naquele sujeito, deve-se distinguir o tempo em que ela age do tempo em que já produziu seu efeito. No tempo em que ela efetivamente age no sujeito, o sujeito sofre continuamente, padecendo da ação daquela causa, contra a qual reage com aquelas forças que tem e que tendem a conservá-lo. Essa luta já é um mal, um sofrimento para o sujeito, que vê em risco algumas de suas perfeições ou sua própria existência. Depois, no tempo em que a causa já prevaleceu e tem, portanto, seu efeito, deve-se distinguir assim: se o efeito foi a destruição ou aniquilação daquele sujeito, não restou depois daquela ação nenhum mal, pois não sobrou nenhum sujeito capaz de mal e de bem. Todavia, no primeiro tempo, enquanto durava a ação daquela causa tendente à destruição daquele sujeito, havia para o sujeito um mal atual, o qual continuou a crescer até o ponto de ser consumada a sua plena e total destruição: e é o sofrer essa violência contínua daquela causa que o destruía e o padecer daquela sucessiva série de degradações que determinou sua dissolução que se chama mal de destruição. Se, ao contrário, o efeito daquela causa foi somente uma diminuição da perfeição do sujeito, mas não a sua total destruição, então esse mal ultrapassa a ação daquela causa, porque lhe ultrapassa o sujeito, sede do mal. Daqui se vê que o mal de destruição existe somente no ato da destruição, quando essa ainda não foi consumada, pois a partir desse ponto, destruído o sujeito, cessa todo mal. O mal de deterioração, por outro lado, tem dois modos, um no ato em que é produzido, que é transitório, outro depois de já ter sido produzido, que é um estado de mal, habitual e permanente. 


\section{$\underline{\text { Artigo VII }}$}

\section{O que é o bem absoluto}

Para evitar qualquer equívoco, vamos distinguir a noção absoluta de bem do bem absoluto.

O ser e o bem não diferem enquanto à coisa.

Todas as coisas, portanto, que têm existência têm também algum grau de bem.

Ora, esse ser qualquer que elas têm, pelas quais são boas em si mesmas, faz, sim, com que se possa dizer lhes convenha a noção absoluta de bem, e essa noção absoluta se destaca daquela noção relativa de bem, pela qual uma coisa se considera boa para uma outra e não para si mesma.

Onde, então, por bem absoluto se entendesse somente isso a que compete a noção absoluta de bem, em tal caso seria possível afirmar que em toda coisa há o seu bem absoluto; distinguindo-se, assim, esse bem absoluto daquele bem relativo, que assim se diria por lhe convir a noção relativa de bem, a qual consiste em ser a causa do bem alheio.

Mas, a considerar de modo mais sutil, encontra-se que, dessas duas maneiras de dizer, "qualquer sujeito tem em si um bem absoluto", e "a qualquer sujeito pode convir a absoluta noção de bem", essa segunda maneira é mais justa e própria, ao contrário da primeira. Pois uma coisa é o bem e outra coisa a noção de bem. A noção de bem quer dizer a ideia, ou seja, o conceito de bem; o bem significa o próprio bem real. Na noção de bem não se distinguem os graus do bem; e, portanto, a própria noção de bem é universal e comum igualmente a qualquer grau de bem, por mínimo que ele seja; essa noção se encontra realizada e verificada igualmente tanto no bem ínfimo como no sumo. Ao contrário o bem real e subsistente tem os seus graus menores e maiores. Portanto, a noção de bem se encontra certamente absoluta e perfeita em todo grau de bem; mas o próprio bem não pode ser absoluto e perfeito, senão quando se encontra no seu sumo e último grau. Há, pois, uma noção de bem absoluta e uma noção de bem relativa. A noção de bem absoluta consiste naquilo a que tendem as forças de cada ser; a noção relativa consiste na atitude de causar o bem alheio. Pode-se, pois, dizer com propriedade que a cada coisa, enquanto é bem para si mesma, compete a absoluta noção de bem; mas não se pode dizer com propriedade que cada coisa seja um bem absoluto (5).

Bem absoluto é somente aquele que tem todo o bem em si mesmo; como o ser absoluto é somente aquele que tem todo o ser em si mesmo. Aliás, o que digo eu que 
tem todo ser em si mesmo? Não devia dizer o que tem todo o ser, mas o que é todo o ser: em suma, o ser completo é o bem completo. O que forma a natureza da nossa inteligência é o ser, mas o ser inicial e potencial: se víssemos esse ser no modo mais perfeito, se o víssemos na sua plenitude, no seu ato, no término do seu ato, veríamos, nesse caso, o ser absoluto. Essa é uma consequência necessária das premissas. Se é verdade que o bem seja o ser, se é verdade que o vemos por natureza, mas imperfeitamente; logo deve ser também verdade que bastaria que a nós se manifestasse mais perfeitamente esse ser, que já está presente na mente e que, com sua presença, a cria, com a sua presença, nos faz racionais, para que fosse verdade que nós víssemos o próprio bem, o bem essencial e, portanto, todo o bem, o bem absoluto. Nada falta a esse ser, nada falta a esse bem e é por isso que ele se diz absoluto.

Mais ainda, nada é, senão pelo ser; portanto, o ser é a origem de todas as coisas, é o ato original de todas as naturezas; e, sendo a origem de todas as coisas, é também a fonte de todos os bens e, como o chama Santo Agostinho (6), "é o bem de todo o bem". Daqui decorre que o ser completo seja não somente o sumo bem em si mesmo e para si mesmo, mas também o sumo bem relativamente a todas as outras coisas.

Ora o ser completo, absoluto, esse sumo e absoluto bem chama-se Deus. 


\section{$\underline{\text { Notas }}$}

(5) N.A. A distinção entre o bem e a ideia ou noção de bem corresponde à distinção entre ser e ideia de ser. A ideia de ser é o mesmo que o ser possível, ou, como ainda costumo chamá-lo, o ser inicial. Esse ser inicial ou ser possível ou ideia do ser (pois todas essas maneiras se equivalem) é o meio concedido ao espírito humano, pelo qual ele conhece as coisas, como foi demonstrado no Nuovo saggio. Só que o homem, a fim de perceber os seres enquanto são subsistentes, e não meramente enquanto possíveis, tem ademais necessidade do sentido, que é a potência que percebe a subsistência das coisas. Mas a percepção da existência das coisas não é conhecimento: para se tornar conhecimento, é necessário que a ele se some o pensamento, ou como se queira chamálo, a intuição da possibilidade, que é apenas a noção universal do próprio ser. Por isso demonstrei que o conhecimento de uma coisa contingente consiste "na visão que o espírito tem da relação entre a sua subsistência e a sua possibilidade"; nessa visão recoloquei o próprio caráter do conhecimento humano. O porquê do ser possível, que é o grande meio do conhecimento humano, é outrossim o que especifica a natureza humana, o que forma seu caráter próprio, que o distingue de todas as outras coisas. Como, pois, há essa distinção fundamental entre o ser em potência, princípio do conhecimento, e os seres em ato, objetos do conhecimento; assim também há a distinção igualmente fundamental entre a noção de bem e o bem em potência, e o próprio bem em ato; e uma mesma distinção se encontra em todas as coisas que conhecemos; por exemplo, entre a noção de belo e o próprio belo, entre a noção de grande e o próprio grande; entre a noção de corpo e o próprio corpo; entre a noção de animal e o próprio animal, etc.

(6) N.A. Santo Agostinho, De diversis quaestionibus, LXXXIII, n. 21: PL 40, p. 16. 


\section{Artigo VIII}

\section{O que é a felicidade}

Agora que já vimos o que entendemos por bem absoluto, podemos formar uma ideia da felicidade à qual o homem tende e da qual trata aquela ciência a que eu propus reservar o nome de eudemonologia, para destacá-la e distingui-la da moral, com a qual misturá-la seria, como disse, a ruína irreparável da própria moral.

Comecemos por ver quais são os bens do homem.

O bem de existência para o homem é a própria existência, ou seja, a natureza humana.

O que é para o homem o bem de perfeição? O homem é um ser misto de duas substâncias, isto é, uma substância corpórea e outra espiritual. Essas duas substâncias subsistem num mesmo sujeito (o $E u$ ), que é o homem. Convém, então, ver qual é o bem de cada uma das duas substâncias, e qual o bem do todo.

Enquanto é sujeito animal dotado de um sentido corpóreo, o homem não é capaz de adaptar a si mesmo e de gozar senão de bem particulares, isto é, os bens corpóreos.

Mas, enquanto é um sujeito intelectivo, o homem percebe todas as espécies dos bens e goza de todas as espécies dos bens por ele percebidos.

O seu intelecto (6) pode ainda atingir o bem absoluto e por isso só esse pode satisfazê-lo (7) totalmente. Ele é o sumo bem das inteligências, no gozo do qual está o que se chama propriamente de beatitude, ou seja, felicidade; nomes que no uso comum da fala são totalmente recusados seja àquela cega e momentânea voluptuosidade da vida animal, seja a qualquer perfeição das coisas insensíveis; e racionalmente deveríamos observar os vocábulos para contrapor um gozo pleno, perpétuo, último e de certo modo infinito, a qualquer outro prazer limitado e instantâneo (8).

E que nada fora desse sumo bem possa saciar completamente o coração humano e torná-lo totalmente satisfeito e alegre, prova-se muito facilmente pela natureza íntima de todo ser intelectivo, que é formada, como tantas vezes dissemos, pela ideia do ser universal. Com esse ser universal, pela sua própria natureza de ser universal, não há coisa alguma ou bem algum que o homem não possa conhecer. Portanto, se a vontade de um ser inteligente se propõe a conseguir qualquer bem menor do que o absoluto, ela pode até ir além, não tem necessidade de parar nos seus desejos. Pois a vontade pode querer tantos bens quantos o intelecto conhecer. Ela segue o intelecto. Ora, o intelecto pode conhecer sempre bens maiores, até chegar ao bem completo, sumo, o bem mesmo, o ser mesmo, o absoluto; aqui para, porque é o último, o infinito; aqui só, portanto, 
pode e deve parar a vontade; nem o desejo dessa potência será jamais exaurido, se ela não conseguir a conquista do bem essencial. E ele está propriamente nessa verdadeira beatitude da natureza intelectiva, que retorna a sua altíssima dignidade: nela consiste sua dignidade, que das outras naturezas o separa e sublima infinitamente. Pois é em virtude dessa estreitíssima união que ela pode se fazer um com o bem absoluto e tornarse um com ele: aqui repousa propriamente a extrema excelência da criatura.

É assim que as outras perfeições das naturezas criadas podem ser tidas em conta de meios, mas essa beatitude tem propriamente a razão e o conceito de fim.

Mas até aqui vimos qual é o bem de perfeição das duas substâncias que concorrem para formar esse sujeito misto, que se chama homem: ora, qual é a relação dessas duas substâncias e qual é o bem do homem como um todo?

A principal relação das duas partes de que o homem se compõe resulta da dignidade da parte intelectiva sobre a animal, da dignidade do bem da primeira sobre o bem da segunda, da relação, em suma, de fim e de meio: já que se só o bem absoluto tem o conceito de fim, todo o resto deve lhe ser subordinado e submetido como meio. E, embora não conheçamos em nossa vida presente o bem absoluto, com um conhecimento positivo e inteiro, e por isso não possamos ver aquele nexo, que, porém, a meditação íntima revela; aquele nexo, digo, pelo qual todos os bens, mesmo os corpóreos, dele derivam e são certas tais comunicações que o ser supremo faz de si mesmo; todavia vejamos que é necessário ser assim e vejamos que entre o bem corpóreo e o bem essencial não pode haver qualquer intrínseca oposição e contrariedade, assim como não há oposição entre uma nascente e um riacho: aliás, de onde um está o outro deve decorrer; e portanto vejamos que com a posse do bem essencial, desse bem do intelecto, o homem não poderia ser privado de toda aquela felicidade, da qual pudesse ser capaz na outra sua parte, isto é, na corpórea; embora essa parte corpórea seja satisfeita de modo a não pôr limites ou impedimentos à satisfação da intelectiva; pois beberá seu júbilo da própria fonte dessa.

Acrescentarei uma observação antes de terminar este artigo: a de que o bem animal, no estado presente, sendo ordenado como meio para o bem intelectual do homem, participa virtualmente da dignidade desse último, em virtude de tal ordenação. O homem sujeito é único: sou eu mesmo quem recebe as sensações corpóreas e quem raciocina sobre elas. Portanto, quem atentasse contra meu corpo atentaria contra MIM, que tenho a dignidade de ser intelectivo, faria injúria ao princípio intelectivo que constitui propriamente a minha personalidade. Todos os bens, portanto, que pertencem 
a um sujeito inteligente, são de modo imediato ou mediado objetos pertencentes à inteligência, que é a parte principal pela qual o sujeito é denominado e especificado. 


\section{$\underline{\text { Notas }}$}

(6) N.A. O intelecto se considera como sentido (e em tal caso chama-se senso intelectivo) quando se observa o seu ato, enquanto não sai do sujeito que entende. Explico: analisemos o pensamento de um objeto qualquer. Esse pensamento se me apresenta em dois aspectos: por um lado é uma paixão que sofre o meu espírito por parte desse objeto que ele pensa; por outro, é um ato do sujeito que termina naquele objeto. Sob o primeiro aspecto, chamo-o sensação, sob o segundo conhecimento. Aquela paixão é uma afeição do sujeito e pode ser considerada toda nele: ela termina,

consuma-se no espírito. É, pois, uma sensação interior, é o ato de um sentido intelectual. Ao contrário, se se considera essa afeição como o meio de conhecer o objeto, considerase o pensamento como um ato do espírito, em virtude do qual o espírito distingue alguma coisa de si; a esse respeito é um ato da faculdade cognitiva. Sentir é, em uma palavra, unir, ensimesmar; conhecer é separar, distinguir de si: sentir pressupõe vários estados de um sujeito identificados pela identidade do sujeito; conhecer supõe uma diversidade absoluta do próprio sujeito cognoscente com a coisa conhecida.

(7) N.A. Na vida presente, esse sumo bem é objeto da fé e, portanto, da esperança cristã. Ele não é visto, mas crido. O mesmo raciocínio, porém, no estado de desenvolvimento que dele temos presentemente, é o que nos conduz a conhecer que o último termo da inteligência não pode ser outro senão o ente absoluto, Deus.

(8) N.A. Os sensistas confundem necessariamente a felicidade com o prazer, e medem os graus de felicidade com os graus do prazer, mas estão errados. De certo, a felicidade é um gozo; mas não um gozo qualquer, ela é o gozo do sumo bem. Ora, entre o gozo do sumo bem e o gozo de um outro bem, não há distância de grau, mas de natureza: distância infinita, em que não há termo médio, que una um extremo com o outro. Essa verdade importante pertence às tradições da antiquíssima escola italiana, que nós, italianos, devemos conservar ao máximo como bela e ilustre herança dos nossos maiores antepassados. O pitagórico Hipódamo de Turio (*), cidade da Magna Grécia, escreveu um livro sobre a felicidade, do qual Estobeu (**) conservou um fragmento, cujas primeiras palavras são: "Entre os animais, uns são capazes de beatitude e outros não. São capazes aqueles que têm razão, pois a beatitude só pode subsistir com a virtude e a virtude se encontra naquele que é dotado de razão. Assim, os que são privados de razão não são capazes de beatitude. Da mesma maneira que aquele que não tem a vista 
não está apto às operações e trabalhos que exigem esse sentido; assim também aquele em que a razão falta não é capaz de entender nem a obra, nem a virtude daquele que a possui”. (Estobeu, Serm. CI)

(*) N.T. Hipódamo de Túrio: provavelmente, a referência é ao urbanista grego Hipódamo de Mileto (498-408 a.C.) que teria planejado a malha urbana da cidade de Túrio, no sul da Itália.

(**) N.T. Estobeu ou João Estobeu (séc. V a.C.) foi um compilador de trechos de diversos autores gregos antigos, reunidos numa obra cujos dois primeiros livros chamam-se Éclogas e os dois últimos Antologia. 


\section{Artigo IX}

\section{Dignidade do sujeito inteligente}

A dignidade do sujeito inteligente nasce, como já disse, da dignidade da ideia do ser, com a qual ele entende.

Pois o ser, primeiramente conhecido e com o qual todo o resto se conhece, é universal, ilimitado e infinito.

Portanto, só ele torna a mente apta ao conhecimento de todos os gêneros e de todas as espécies de bem e ao gozo desse conhecimento. A natureza desse conhecimento e desse gozo tem uma dignidade verdadeiramente suprema no seu gênero e infinita, pois com ela o sujeito inteligente se esquece de si mesmo para considerar as coisas como são em si; e por isso ele tem um olhar imparcial e justo; com isso presta, como disse, um obséquio ao próprio ser em todos os seus diversos graus em que os enxerga, sem relação a si. Essa objetividade que se encontra na contemplação intelectiva, eu disse, tem qualquer coisa de infinito, porque não é restrita por nada; está apta a fazer conhecer as coisas como são, sejam como for, mesmo infinitas: ora, a infinidade é propriamente o princípio da dignidade, pois onde há qualquer coisa de infinito há qualquer coisa de tão grande, de tão augusto, a que cedem como menores todas as coisas finitas, e se curvam a um sentido sublime do próprio nada e da ideia de um ente que as vence, cuja grandeza confusa e misteriosa recebe em qualquer parte uma ilimitada reverência. A primeira dignidade do sujeito inteligente, portanto, consiste na contemplação da verdade.

Em segundo lugar, aquela própria visão com que o sujeito inteligente vê o ser universal é aquela com que veria o ser absoluto e subsistente, se esse ser que vê se revelasse mais descobertamente a ele, isto é, se se mostrasse não só como ideal, mas também no ato do seu subsistir. A inteligência, pois, com o sentido intelectivo de que é dotada, está ordenada a perceber o ser absoluto e o bem absoluto, portanto, novamente o infinito, e somente percebendo isso suas forças se podem exaurir. Ora, semelhante ordenação ao ser absoluto e infinito, é o segundo motivo da dignidade do ser intelectivo; pois esse ser está ordenado a tão alto bem, que a maior não poderia.

Finalmente, a percepção do ser absoluto é uma união, uma possessão do ser absoluto, do qual procede a beatitude, isto é, um gozo infinito; e a capacidade de gozar dessa beatitude é o terceiro e último motivo da dignidade do homem e de toda outra natureza inteligente. 
Essa felicidade, portanto, a que o homem tende incessantemente, e os meios com os quais pode consegui-la são o argumento da eudemonologia. Passemos agora à moral e procuremos penetrar mais intimamente a sua natureza. 


\section{Capítulo IV}

\section{A ideia do ser considerada como o princípio da moral \\ $\underline{\text { Artigo I }}$}

\section{Resumo das doutrinas expostas}

Recolhendo agora tudo o que vimos até aqui, para nos colocarmos naquele caminho do qual nos afastamos por desejo de indicar a natureza de uma ciência que trata do bem subjetivo do homem e que da moral difere essencialmente, havíamos encontrado:

1) Que a ideia do ser é a regra suprema de todos os juízos que a mente humana faz.

2) Que, por conseguinte, é a suprema regra dos juízos morais, ou seja, a primeira e mais universal das leis.

3) Que essa lei, reduzida a uma fórmula, seria assim expressa: "Segue a luz da razão", a fórmula mais extensa que todas as outras que se podem expor na ciência moral.

4) Que, mesmo sendo o ser ideal a regra não só dos juízos morais, mas de todos os tipos de juízo, ele é um princípio da moral, comum a mais ciências.

5) Que, sendo o ser e o bem a mesma coisa, a noção do ser é também a noção do bem e, por isso, a ideia do ser é especialmente o princípio de todas as ciências que tratam do bem.

6) Finalmente, que não basta ter indicado um princípio comum, mas que convém assinalar o princípio próprio de cada ciência; e que o princípio próprio da eudemonologia é a noção de bem subjetivo do homem, ou seja, a felicidade.

Ora, portanto, fica faltando procurar qual é o princípio próprio da ciência moral, o que começaremos a fazer neste capítulo.

E é evidente que onde se conseguir encontrar e bem descrever esse princípio da ciência moral, também se conseguirá com isso mesmo espargir luz sobre a primeira e suprema lei moral; teremos, então, ilustrado essa aplicação nobilíssima do ser; esse uso do lume da razão, uso de todos certamente mais preclaro e mais importante: teremos respondido em uma palavra à pergunta que nos propusemos e a que ainda não satisfizemos: "de que maneira o ser serve praticamente ao homem como regra para discernir o justo do injusto, o honesto do desonesto?" 


\section{Artigo II}

\section{O que é o bem objetivo}

Para saber de que modo a noção de ser pode prestar o serviço de regra moral, convém esclarecer em que consiste a essência da moralidade, o que é o bem moral.

Este é certamente de um gênero de bem e isso só basta para entender que, para fazer juízos sobre ele, precisamos primeiramente da noção de bem em geral; pois não podemos saber o que é um bem especial, se não soubermos primeiro o que é o bem. Ao definir, pois, o bem moral, o que fazemos é determinar e restringir a noção universal do bem e, assim, torná-la própria da ciência moral, a qual não trata do bem em comum, mas de um bem especial, isto é, o moral. Ao haver determinado e depois restrito a noção de bem, com os caracteres que o tornam moral, nós o teremos tornado de princípio comum em princípio próprio dessa ciência e mostrado de que modo, por que caminhos e por que gradação a ideia do ser decline, por assim dizer, e se aproxime dos bens e males morais, revelando-se para nós e nos iluminando para o conhecermos, distinguirmos e medirmos. Os primeiros princípios não podem nunca ser aplicados imediatamente pela sua universalidade, mas mediante outros princípios menos universais que dele descem e que formam o elo intermediário entre os universalíssimos e as coisas totalmente particulares.

O que é, pois, o bem moral?

Para tornar clara a sua noção, devo começar dizendo algumas palavras sobre o bem objetivo.

Por bem objetivo, designo todo bem enquanto é percebido objetivamente, isto é, enquanto se faz objeto de conhecimento.

Dissemos que a noção absoluta de bem consiste naquilo que é conveniente à ordem intrínseca do ser de toda natureza, naquilo que cada coisa, com todas as forças de que dispõe, tende a conseguir; ao passo que havíamos concebido a noção relativa de bem no ser uma coisa apetecível a outra, no ser o fim e o escopo das forças naturais de uma outra, as quais se inclinam e tendem a arrebatar aquela coisa para si e unir-se a ela. Com essas noções, conhecemos dois gêneros de bens, o bem das coisas em si e o bem das coisas relativamente a outras coisas: essas duas espécies de bens se fazem objetos da nossa inteligência e assim se tornam objetivos.

Nosso entendimento é um ato universal por sua própria natureza, isto é, é próprio da nossa faculdade de conhecer o conceber a própria razão ou conceito de bem, em vez do próprio bem; no entanto, o homem que possui essa faculdade pode conhecer 
tudo aquilo a que a noção de bem se estende: o que mostra a universalidade do ato intelectual que apontamos. O entendimento, portanto, concebe todas as espécies de bem, o que quer dizer que o homem pode considerar objetivamente todos os bens.

Pode-se dizer o contrário do sentido corpóreo, que não concebe a razão do bem, mas percebe o próprio bem e somente aquele bem particular que lhe é conveniente e proporcionado: só deste pode gozar.

Daí que, com sua inteligência, o sujeito intelectivo une a si, de algum modo, todas as naturezas dos bens e ainda goza das mesmas. E, ainda que não se possa dizer que só o conhecimento dos bens é a plena posse dos mesmos e seu gozo perfeito, pois com o conhecimento não se goza propriamente do bem mesmo, mas só da noção ou razão do bem; todavia, da concepção da só razão abstrata dos bens também se gera no ser inteligente tal nobilíssimo júbilo, ainda que não sólido e perfeito. Do que decorre que o espírito inteligente, mesmo nesta vida, tem consigo tal sentido intelectual (1), com o qual goza das próprias essências ou conceitos do bem, sentido que não se limita só, como o corpóreo, a um bem restrito e particular, mas se expande de modo a alimentar-se de todos os objetos da inteligência, e deduz o seu prazer não de si mesmo, mas de todas as coisas em si mesmas, isto é, objetivamente consideradas.

Mas, para conhecer melhor a natureza desse bem objetivo, confrontemo-lo com o bem subjetivamente considerado. 


\section{$\underline{\text { Nota }}$}

(1) N.A. Esse sentido intelectivo era conhecido de toda a Antiguidade e da doutrina da tradição eclesiástica. Santo Agostinho, nas suas Retratações, repreende-se por ter escrito em um livro seu "deve-se desprezar isso que o sentido percebe", quando the seria conveniente ter escrito "isso que percebe o sentido mortal; pois, diz ele, est sensus et mentis. Todavia logo depois desculpa-se a si mesmo com estas palavras, que valem também para minhas declarações nos lugares em que eu fiz uso da palavra sentido para indicar somente o corpóreo: Eorum more tunc loquebar, qui sensum non nisi corporis dicunt et sensibilia non nisi corporalia. Itaque ubicumque sic locutus sum, parum est ambiguitas evitata, nisi apud eos quorum consuetudo est locutionis huius. Retractationes, I.I,2. 


\section{Artigo III}

\section{Relação do bem objetivo com o bem subjetivo}

Digo, portanto, que há no homem duas faculdades fundamentais, que percebem as coisas de modo diverso, o sentido e o intelecto, e esse modo diverso de perceber é a razão da distinção que se quer fazer entre o bem subjetivo e o bem objetivo. O sentido é fonte do bem subjetivo e o intelecto, do bem objetivo.

Em verdade, todo bem sensível é sempre subjetivo, isto é, bem para aquele sujeito que o une a si e, com essa união, o sente. Mas, ao contrário, o bem, não enquanto é sentido, mas enquanto é simplesmente intuído pela mente e pensado, o que às vezes se chamou, por brevidade do discurso, bem inteligível, diz-se objetivo, porque o homem não o considera como pertencente a si, mas, não importa onde esteja, do modo que é. Em verdade, se o bem subjetivo é um bem gozado por um sujeito particular, esse bem só pode ser sensível, pois é só o sentido que goza, seja, pois, esse sentido corpóreo ou espiritual. Ao contrário, a maneira pela qual o entendimento vê o bem é a causa da denominação objetivo. Em suma, se é inteligente, o sujeito, além dos próprios bens, pode conhecer também muitos outros bens e, portanto, saber que são bens, embora não sejam bens para ele; entretanto, se não houvesse a razão, todos os bens que não experimenta sensivelmente, para ele nem sequer existiriam.

O bem objetivo, portanto, estende-se bem mais do que o bem subjetivo, pois o subjetivo é o bem próprio do sujeito; mas o objetivo é bem de qualquer um, seja ele do próprio sujeito que o contempla (e, portanto, subjetivo) ou não, não significando a palavra objetivo senão contemplado, no modo como é, pela inteligência.

E, para melhor esclarecer, coloquemos em outras palavras essa relação que ocorre entre o bem subjetivo e o objetivo.

Já demonstrei que o sujeito humano (o $E u$ ) é essencialmente senciente, aliás é ele mesmo um sentimento substancial (2). Todas as sensações são somente modificações desse $E u$, modificações desse sentimento, o qual em parte é imutável e em parte mutável. A parte imutável forma a sua identidade, a parte mutável dá lugar à variedade das sensações que sofre. Ele, portanto, sente sempre a si mesmo, ou melhor dizendo, o modo do seu ser: o sentir é inseparável do sujeito, começa e termina no sujeito, ou se identifica propriamente com ele. Portanto, fica patente como o bem subjetivo tem origem no sentido.

Por oposição, a inteligência tem um caráter totalmente contrário ao sentido. Com a inteligência se concebe e conhece sempre objetivamente, isto é, o ato da 
inteligência começa, certamente, no sujeito, mas termina em um obejto, o qual é concebido como independente do próprio sujeito que o concebe, aliás, com a exclusão dele mesmo, que, ao conceber, jamais concebe a si mesmo, mas só o fim da sua concepção. Portanto, é unicamente com a inteligência que se pode conceber o bem em si mesmo; eis como vem dela a origem do bem objetivo.

Apesar de o sujeito intelectivo, com o ato do entendimento, terminar em algo diverso de si, isto é, nos objetos do seu entendimento considerados em si mesmos; todavia, como dissemos, também disso mesmo lhe vem um gozo singular. E quem não sabe quão deleitável é para o homem o conhecimento? Quem não percebe a verdade dessa sentença de Cícero: "Natura inest mentibus nostris insatiabilis quaedam cupiditas veri videndi?" (I). Em suma, há um sentido da mente, com o qual o homem saboreia todos os objetos dele conhecidos; e, no entanto, o bem objetivo, para o ser inteligente, sempre se faz também subjetivo, por um tal efeito de gozo que provoca (3) no ser inteligente. Mas o que se deve admirar, sobretudo, é a pureza desse gozo, pois ele se gera no homem por uma causa completamente oposta àquela que ocasiona o prazer que se encontra no bem puramente subjetivo. O sujeito puramente sensível goza o bem subjetivo, porque esse bem termina todo nele. Ao contrário, o sujeito intelectivo goza o bem objetivo justamente por isso: ao pensar o bem objetivo, sai de si, e entretém-se e alarga sua existência nos outros objetos com a sua mente; goza por poder contemplálos neles mesmos e, portanto, imparcial e plenamente, não só em uma relação singular consigo; goza, enfim, porque é em si consciente de exercer sobre aqueles objetos um ato de justiça, reconhecendo os méritos sem nenhuma referência a si mesmo; e essa justiça, esse desinteresse, essa homenagem à verdade, que se encerra essencialmente no ato do conhecer, e se consuma depois com a adesão da vontade, é propriamente o que produz no sujeito inteligente aquele sublime deleite, que acompanha o conhecimento. 


\section{$\underline{\text { Notas }}$}

(2) N.A. Nuovo saggio, vol. 3, págs. 126 e segs.

(I) N.T. Cícero, Marco Túlio, Tusculanae disputationes, Liv. I, cap. 19. Em português: "A natureza introduziu em nossa mente um insaciável desejo de procurar a verdade." (3) N.A. O contrário não é verdadeiro, isto é, que todo bem subjetivo produza esse efeito de tornar-se ele mesmo objetivo. Isso só ocorre quando se trata do bem absoluto. 


\section{Artigo IV}

\section{Relação entre o bem objetivo e o bem absoluto}

Depois disso, para esclarecer a natureza do bem objetivo, será útil compará-lo ainda ao bem absoluto.

Como já dissemos, o bem absoluto e o ser absoluto são o mesmo; dissemos ainda que a mente em seu estado presente vê o ser e o usa para conhecer tudo o que conhece, mas o vê apenas inicialmente, em potência; e finalmente, que se esse ser em potência passasse ao seu ato, este mesmo ser visto pela mente passaria do estado de idealidade ao de subsistência e, nesse caso, seria o ser absoluto; a mente então veria Deus. O ser absoluto, portanto, é essencialmente um ser objetivo, isto é, só pode ser possuído pelo homem mediante um ato de sua inteligência. E todavia, enquanto a inteligência atinge esse ser, que é o seu próprio bem, diz-se com propriedade existir um senso intelectivo; já que o sentido é aquela potência com a qual se percebem as coisas subsistentes, diferentemente do intelecto tomado como faculdade de conhecer, que intui as coisas possíveis. 


\section{Artigo V}

O bem objetivo origina o bem moral, assim como o bem subjetivo origina o bem eudemonológico

Depois de tudo o que ponderamos até aqui, ainda resta, todavia, saber o que é o bem moral, escopo de nossas pesquisas e agora já é bem tempo de nos aproximarmos dele e esclarecermos sua natureza.

O bem moral é o bem considerado subjetivamente ou, em vez disso, objetivamente?

Sem dúvida, o bem moral é objetivo e não subjetivo. O sujeito, que procura satisfazer somente a si mesmo, nada faz ainda de moral: obedece o instinto (5) do prazer ou da felicidade, mas não põe nisso nenhuma olhar aos outros seres, que têm os mesmos direitos que ele ou ainda maiores: em suma, enquanto pensa só em si mesmo, não se eleva a nenhum conceito nobre, reencerra-se em um amor próprio, em um egoísmo, recusando a ter em qualquer conta os bens que estão certamente presentes ao seu conhecimento, mas que ele não pode possuir. Em uma palavra, o sujeito é formado pelo sentido do qual tem a natureza e cujas leis observa.

A inteligência, ao contrário, não se limita ao bem subjetivo, como vimos, concebe indiferentemente todos os bens, considera-os em si mesmos: mede os seus graus imparcialmente, pois tem a ideia do ser, que é a medida própria aos vários graus da existência e, portanto, dos vários graus de bem; em uma palavra, considera o ser e o bem objetivamente e, nessa maneira de considerar o ser e o bem, consiste essencialmente um desinteresse e, como já dissemos, um exercício natural de justiça, que torna nobre o ato da inteligência; desse modo, só no bem objetivo se pode procurar o bem moral, já que só no ato da razão se encontra o princípio da justiça, o princípio de dar a todos o que é seu, que é também a grande fórmula da legislação moral.

Com esse raciocínio, nos encontramos reconduzidos à primeira lei moral, já por nós assim expressa, desde o começo: "Age segundo o lume da razão", lei que, pelo já exposto, é confirmada e esclarecida, assim como se torna evidente o erro daqueles filósofos que gostariam de fabricar a moral sobre o prazer, ou sobre o interesse, não importa quanto pretendam tê-la bem entendido. Pois a moral, antes que de prazer e de interesse próprio, trata inteiramente de dever e de obrigação. O prazer e o interesse, entendidos não importa como, têm sempre em última referência o sujeito, enquanto o dever, a obrigação volta-se sempre para um objeto que se considera em si mesmo com a inteligência. Daí que Helvetius, na França, Bentham (I), na Inglaterra, e Gioia e 
Romagnosi (6) na Itália confundiram o sujeito com o objeto e, por essa distinção ter escapado a sua atenção, aniquilaram a moral, reduzindo-a a uma arte de bem cuidar dos próprios interesses. Ao contrário, nós, distinguindo acuradamente o sujeito do objeto, vemos neles os dois princípios de duas ciências inconfundíveis entre si e totalmente opostas; uma dessas ciências, que extrai o seu princípio do objeto, trata da moralidade e só a ela chamamos Moral; a outra, que tira seu princípio do sujeito, trata da felicidade e a denominamos Eudemologia; e se não estamos enganados, parece-nos que nem mesmo os antigos haviam distinguido suficientemente essas duas ciências de todo diversas; e, aliás, formando um só ciência prática, sem perceber, as mesclaram e confundiram, falando juntamente de coisas que ora pertenciam a uma, ora a outra; apesar de serem muitos os lugares nos quais mostram haver sentido a disparidade e a contrariedade do honesto e do útil.

Portanto, o ato moralmente bom tem por termo o bem objetivo, isto é, o bem enquanto é assim contemplado e julgado pela inteligência. Por isso, um ser não é moralmente bom na medida em que seu instinto o move e impele ao seu próprio prazer, ao seu próprio bem: nesse movimento, ele não tende ao bem porque é bem, mas ao bem porque é próprio: é a si mesmo que ama e não o bem como tal: portanto, é um amor restritivo, que exclui outros bens, porque não são próprios, e à medida que os exclui é ainda uma injustiça, um desamor, uma depravação. Mais acima se eleva o olhar do homem moralmente bom, que é, segundo a fórmula por nós obtida, a do homem que segue com seu amor o lume da razão: ele ama o bem em si mesmo, na sua própria natureza de bem, como este lhe é mostrado pela inteligência e, portanto, o ama onde quer que ela o mostre: ama, por isso, todos os bens, e da sua contemplação extrai, querendo-o, aquela nobre e pura alegria que é o efeito natural do bem conhecido em um ser inteligente e bom: ele não olha a si mesmo porque a inteligência que segue não vê isso, porque ela, por sua natureza, prescinde do sujeito, está sempre fora dele, sempre independente, impessoal e absoluta: é a própria verdade, a própria imparcialidade; ele ama, portanto, os objetos, os seres todos e, por isso, assim como a fórmula da inteligência é a vista do ser universal; assim a fórmula da moral é o amor universal, o amor de todos os seres, de todos os bens, amor que tanto se estende, como se estende o conhecimento, ao infinito.

É igual, portanto, dizer "segue o lume da razão" e o dizer "ama todos os seres", pois o que o lume da razão nos mostra e apresenta são os seres, e os apresenta para que 
nós os amemos, sendo o lume da razão o que nos mostra em cada ser um bem, em cada ser uma ordem interior, isto é, uma ordem que emerge da constituição do próprio ser. 


\section{$\underline{\text { Notas }}$}

(5) N.A. Às duas faculdades passivas que distinguimos no homem, o sentido e a inteligência, correspondem duas ativas. Ao sentido corresponde o instinto, à inteligência, a vontade: o instinto se inclina ao prazer e à felicidade, mas a vontade é o princípio de moralidade.

(I) Jeremy Bentham (Londres, 1748 - Londres, 1832), filósofo e jurista, difusor do utilitarismo, teoria ética normativa que se objetiva a responder todas as questões acerca do fazer, admirar e viver em termos da maximização da utilidade e da felicidade. Ou seja, para ele, as ações devem ser analisadas diretamente em função da tendência de aumentar ou reduzir o bem-estar das partes afetadas.

(6) N.A. Refutei Gioia (*) na Breve exposição da sua filosofia, que publiquei também nos Opúsculos filosóficos (vol. II, pp. 105 e seg.), onde me parece estar reduzida à evidência essa verdade, de que a moral não pode edificar-se minimamente sobre um cálculo dos prazeres como pretendia esse escritor, o qual produziu um infinito dano à juventude italiana com uma filosofia baixa e material, e com um estilo aparentemente claro, mas, em verdade, desconexo, frio e superficial. Mas é um grande conforto para mim poder acrescentar que esse sacerdote, antes de morrer, lamentou seus erros e os seus desvios e declarou o desejo de que o público fosse informado disso. Quanto a Romagnosi (**), veja-se o que dissemos dele em Renovação da filosofia na Itália.

(*) N.T. Melchiorre Gioia (Piacenza, 1767- Milão, 1829), economista, político e intelectual, cujo pensamento reflete influência do utilitarismo de Bentham, do empirismo de Locke e do sensismo de Condillac.

(**) N.T. Gian Domenico Romagnosi (Salsomaggiore, 1761- Milão, 1835), jurista, filósofo e físico; como filósofo foi um convicto defensor da "filosofia civile", isto é, de uma reflexão que estuda o homem na sua evolução histórico-social concreta, unindo a dimensão moral à jurídico-política e econômica. 


\section{Artigo VI}

\section{O bem moral é obra da vontade}

Mas, se o bem objetivo é o bem moral, em que condição ele se torna moral?

Na condição de que ele seja querido pela vontade.

Enquanto o bem serve apenas de objeto para a mente, enquanto ele se põe apenas diante da inteligência para lhe servir de espetáculo e nada mais, até que uma vontade não se apresente para querê-lo, depois de tê-lo conhecido, ele não adquire a natureza e o nome de bem moral.

O conhecimento do bem, um conhecimento especulativo, necessário, estéril no sujeito que o possui, não apresenta de modo algum a noção de bem moral. É quando o sujeito quer aquele bem que conhece com a mente, que esse bem, enquanto começa a ser querido, começa também a ser propriamente moral.

A vontade é a potência com a qual o sujeito inteligente (7) atua: é com essa potência que ele se torna autor de suas ações; sem ela, bem pode desenvolver-se nele uma longa série de fenômenos, mas todos esses fenômenos que nele se desenvolvem e sucedem, quaisquer que sejam, não têm ainda ele mesmo por causa; se ele não intervém com a sua vontade: de certo modo, ele não é senão o cenário em que atores estrangeiros, desconhecidos, representaram um drama qualquer, no qual, contudo, ele não tomou parte como ator, mas tão somente como um simples espectador. Nem toda coisa que em nós ocorre é feita por nós; outras potências, outras forças atuam no homem. $\mathrm{O}$ homem só atua quando atua a sua vontade; essa vontade na qual está a propriedade das ações é também aquilo em que se cumpre a personalidade humana. Portanto, o homem não pode ser moralmente bom, se ele não é a causa, o autor do bem moral que lhe é atribuído, que dele se predica, e como a vontade é a potência ativa da inteligência humana, assim também o bem moral não é, finalmente, senão "o bem objetivo conhecido pela inteligência e querido pela vontade".

É, portanto, nessa relação do bem objetivo com a vontade que o bem moral consiste, o que contribui para esclarecer mais a noção. 


\section{Nota}

(7) N.A. "O objeto da vontade", diz São Tomás, "move determinado ato daquela potência de modo a operar um princípio formal", isto é, essencialmente ativo, que dá o movimento e prescreve a maneira desse movimento. Ora, qual é o princípio formal que move a vontade segundo o doutor de Aquino? É o ser, aquele ser que é também objeto do intelecto. Ouçamo-lo dele mesmo, que logo acrescenta: Primum autem principium formale est ENS et verum universale, quod est obiectum intellectus: et ideo - conclui isto modo motionis intellectus movet voluntatem, sicut praesentans ei obiectum suum. Suma Teológica, I, II, q. 9 art. 1. (O princípio formal é o ente e o verdadeiro universal, o objeto da inteligência. Por isso, esse gênero de movimento do intelecto move a vontade, enquanto lhe apresenta o próprio objeto.) 


\section{Artigo VII}

\section{No bem moral há ordem}

Depois do que dissemos até aqui, não deve haver dificuldade em compreender que o bem moral é um bem ordenado, de tal modo que a vontade que ama o bem, ama por isso mesmo a ordem que no bem se encontra essencialmente.

Pois, resumindo, vimos:

Que o bem e o ser são o mesmo;

Que o ser é dotado de uma ordem intrínseca, de uma constituição própria sua;

Que o ser aparece à mente como bem, logo que ela o considera em sua ordem intrínseca e essencial;

Que, por isso, o bem é o que convém a qualquer natureza, isto é, o que está de acordo com a ordem interior de cada ser;

Que ele é isso a que as forças constituintes de cada natureza tendem incessantemente;

Isso que o entendimento naturalmente aprova, porque o próprio entendimento tende a seu objeto que é certamente o ser e, portanto, é também a sede da ordem do ser intrínseco e arraigado; tende, por isso mesmo, a contemplar essa conveniência das coisas com a sua natureza íntima, esse quase desejo de todas as coisas; conveniência que se logo se torna certamente o próprio bem do entendimento.

Além disso, vimos também que esse ser e, nele, essa ordem e, por essa ordem, essa conveniência das partes de uma coisa entre elas, e de umas coisas às outras, esse bem, enfim, doce objeto e dileto espetáculo da inteligência, quando é querido pela vontade, recebe, justamente da relação com ela, a natureza e o nome de bem moral; e que o homem se torna moralmente bom por isso: por se tornar com a sua vontade autor do bem também por querê-lo ou porque ele forma com o bem a sua complacência, não o odeia, não se opõe a ele, não se une com seus afetos ao mal.

Portanto, foram conduzidos a um alto e veríssimo pensamento aqueles filósofos que colocaram na ordem o princípio da moral. No entanto, não chegando à primeira fonte da ordem mesma, eles não puderam mostrar a última razão dessa ordem e assim justificá-la plenamente, assim torná-la necessária, torná-la autoral, buscando-a em um princípio evidente, que está acima de todas as forças do raciocínio que quisesse refutála, pois está acima do próprio raciocínio, já que este se inicia naquele princípio e dele tira autoridade e força; a essa lacuna, que tirava a evidência do sistema moral, parecenos possível satisfazer com a teoria que propomos, na qual remontamos essa mesma 
ordem a um princípio mais alto, isto é, ao ser, em que a ordem admiravelmente se origina, como em sua própria e nativa sede.

Só desse modo consideramos legitimamente deduzida e explicada a ideia da justiça e da honestidade, e revelada a nobre estirpe dessa ideia, que é tão alta, que ascende até o primeiro conhecido, àquele ponto onde a natureza intelectiva tem o seu berço, até a luz claríssima e evidentíssima da mente, que a ninguém pode repugnar e que ninguém pode apagar em si mesmo, porque é a palavra divina, que onde soa, ali cria.

O homem, portanto, vê o ser com a sua inteligência e, vendo o ser, vê a ordem do ser e esse ser é o bem: e a vontade que ama o ser e a ordem do ser é a boa vontade, a vontade que quer o bem e que, por querê-lo, torna-o moral.

Portanto, a fórmula da ética, "segue o lume da razão", perde um pouco de sua indefinição e começa, com o que dissemos, a tornar-se mais precisa e mais determinada, podendo já se traduzir nesta outra: "Queira ou ame o ser onde quer que o conheça, na ordem em que se apresenta para a sua inteligência”.

Não é, decerto, necessário provar que a inteligência conhece a ordem do ser também com o mesmo ato com que conhece o ser, pois a ordem de que falamos não é já algo distinto do ser, mas é o que constitui o seu modo, se me é permitido usar aqui um tal vocábulo, é o ser como ele é, nem mais nem menos e, portanto, como é concebido pela inteligência, a qual concebe justamente cada coisa tal como é. E essa ordem que a inteligência concebe simultaneamente com o ser, que é objeto de uma mesma intelecção (se bem que imediatamente sobrevenha a reflexão para analisá-la e nela dividir uma coisa da outra, para separar o que em princípio está unido e permanece sempre, de fato, indivisivelmente unido), descobre-se e manifesta-se primeiramente em cada objeto que se contempla, no qual reluz a harmonia das partes, da qualidade, dos mesmos acidentes, e revela-se algo que constitui, quase direi, o seu fundamento, a sua essência, e algo que àquele fundo se acrescenta, que aquela essência continua como acabamento conveniente; e em segundo lugar refulge ainda em muitos objetos concebidos simultaneamente pela inteligência e relacionados entre si.

Pois é certamente a inteligência que pesa e mede os diversos graus por assim dizer do ser, que mede o ser onde quer que esteja e, já com o ato de percebê-lo, percebendo-o aqui maior, ali menor; e, portanto, é também a inteligência que pesa e mede os diversos graus do bem e que, em consequência disso, ordena para si mesma os 
bens segundo o seu valor, distinguindo nestes o mais e o menos e pospondo os menores aos maiores: o que já é uma determinação da ordem do ser.

A título de exemplo, é evidente à inteligência que um ente que não sente é inferior em mérito ao um ente sensível, pois a inteligência vê que o ente que não sente não existe para si mesmo e, portanto, lhe falta esse modo de existir que o outro possui; julga também que o ente sensível tem um modo mais nobre de existência e que em relação a esse ser, o que é privado de sentido é como um nada, privado como é daquela atividade de sentir mais ou menos diversamente. Do mesmo modo, a inteligência só tem de perceber simplesmente o ente sensível e o ente intelectivo, a fim de, confrontando-os, discernir e encontrar, com um primeiro e muito fácil juízo, que esse segundo é um ente muito mais nobre que o primeiro, porque o primeiro desconhece a si mesmo, sendo portanto nulo na ordem do conhecimento; mas o segundo conhece que existe e sente, e assim, acima dessas duas atividades, sobre esses dois modos de ser, há uma terceira atividade, um terceiro modo a mais que os outros dois. Não só por isso, mas principalmente pela grande e única excelência do entender; pois o sujeito, em virtude da inteligência, tem um tal ato de ser, pelo qual se estende quase ao infinito, unindo a si mesmo com o ser em geral e dele se informando, dele participando, e conquistando assim uma capacidade infinita, isto é, a capacidade do infinito. Todos esses juízos são feitos, então, com facilidade pela mente com a noção do ser, com a qual percebe, como eu disse, e mede aqueles vários graus, aqueles vários modos de ser, e entende aquelas diversas relações que têm as naturezas subsistentes com aquela noção primeira.

Além disso, a inteligência desenvolve rapidamente esses juízos.

Depois de haver percebido os diversos seres subsistentes, de havê-los comparados entre si, distinguido os maiores dos menores, apontado a cada um o seu lugar, o grau de sua dignidade e excelência; é claro que não lhe custa muito mais medir e conhecer também os diversos graus de bondade ou de depravação moral, de que pode ser dotada uma vontade que ama ou odeia esses diversos seres. Pois a bondade dessa vontade é tanto maior quanto maior o ser que ama, e quanto maior é a intensidade a partir da qual ela se leva àquele ser; e a maldade dessa vontade é igualmente tanto maior, quanto maior é o ser que odeia e quanto o próprio ódio é mais intenso; e, portanto, a inteligência tem os dois elementos necessários para julgar a moralidade, os quais são a quantidade do ser amado ou odiado e a quantidade da intensidade do amor ou do ódio. 
Assim, a inteligência tem a posse das normas gerais, com as quais pode julgar as ações morais que se referem aos diferentes seres e que procedem do amor ou do ódio para com esses seres.

Mas, rapidamente, devendo pronunciar tais juízos, apresentam-se ainda à inteligência os casos particulares, nos quais ela é obrigada a descer para formar-lhes normas particulares, que são consequências das gerais, e se mostram de modo explícito e próprio justamente por ocasião das aplicações diversas que delas se fazem. A título de exemplo, no caso de conflito entre o bem de dois seres e, portanto, entre dois bens, um em contradição direta com o outro de tal modo que a obtenção de um exclua a do outro, que quem é favorável a um torne-se necessariamente desfavorável ao outro e a existência de um não ocorra sem a destruição do outro, é claro que, no caso de um tal conflito, o homem, do princípio universal de que o bem moral está no amor do ser objetivo e que, portanto, se deve querer e amar o ser o mais que se possa, vai dela induzir a consequência que ele, portanto, deve preferir o ser maior ao menor, o bem maior ao menor, e abandonar esse por amor daquele, amando-se assim a maior quantidade de ser possível; dela vai induzir ainda a consequência que aquele amor ao bem menor, que inclui e necessita o ódio ao bem maior, não é um verdadeiro amor do ser, um verdadeiro amor do bem, mas um amor aparente, ilusório, e, ao contrário, é um ódio real, um ódio efetivo e, portanto, uma imoralidade; dela vai induzir, finalmente, que querer e conseguir um bem menor em detrimento de um maior, não é propriamente um querer e um conseguir um bem, mas sim um querer e um conseguir um mal.

De todas essas observações decorre que o ato moralmente bom tende ao ser sem exclusão, sem reserva, e, portanto, tende necessariamente à ordem que no "ser" se encontra, pois remover a ordem é limitar o ser, é não amá-lo mais na sua integridade, na sua totalidade, já que o ser é interiormente e essencialmente ordenado, é, como dissemos, a sede e a fonte primeira de toda ordem.

É verdade, então, que no bem moral há ordem, pois o bem moral é o "ser" querido por si mesmo pela vontade e, quando a vontade busca somente o ser, ela encontra necessariamente essa ordem que é somente, como dissemos, a modalidade do próprio ser. 


\section{Artigo VIII}

\section{$O$ ato moralmente bom tem sempre por fim o bem de um ser inteligente e tende ao absoluto}

Para ser boa, portanto, a vontade deve nada odiar, amar tudo e amá-lo em sua ordem natural.

Mas qual é essa ordem? Qual é a ordem dos bens? Qual a ordem dos seres?

Vimos que os seres privados de inteligência só têm existência relativamente à inteligência e que ocupam somente o lugar de meios em comparação com os seres inteligentes. Por isso, é impossível que eles retenham ou que neles termine o amor de uma inteligência, pois neles não termina, não se cumpre o conceito do ser. Ao contrário, vimos que os seres inteligentes tem uma certa dignidade infinita, que os eleva sobre todos os seres irracionais: que só eles podem ter a razão de fim de uma boa vontade e essa razão de fim que têm os seres inteligentes é o que constitui a sua personalidade, palavra com a qual designamos tudo o que há de mais nobre na natureza humana e em geral nas naturezas inteligentes (8). Portanto, o ato volitivo moralmente bom deve ter por objeto final o bem das próprias inteligências; não pode sossegar antes de vir a amar esse bem, pois esse ato segue o ato do intelecto e o intelecto não encontra nenhum ser, entre aqueles que conhece, que tenha uma existência assim tão própria sua, que rejeite servir de meio a um outro ser e que seja, nesse sentido, fim em si mesmo, ou aquele que tem em si o caráter augusto que imprime nele o lume do entendimento.

Mas de onde e como vem às naturezas dotadas de intelecto tanta dignidade? De onde e como advém que tenham essa razão de fim da qual falamos? Isto é, como ocorre que, pensando nelas, pensemos necessariamente em algo de tão grande, de tão absoluto, que, mais além, em qualquer sentido, não podemos ir, convindo sossegarmos nelas e amá-las por si, isto é, por algo de supremo e de último que nelas encontramos, podendo, por isso, e devendo nelas assim finalizar o amor? Que é esse algo de supremo e de último que as eleva? Que elemento divino as retira dos confins, que, porém, as limitam, e as fazem se estender, por assim dizer, ao infinito?

A essas interrogações, o leitor sabe como respondemos, depois de tudo que refletimos sobre a dignidade humana. É o ser universal que está presente nas naturezas racionais e que as ilumina, esse elemento que é manifestamente uma centelha do fogo

divino. É por entenderem o ser universal que essas naturezas entendem, que entendem todos os seres particulares, e que, percorrendo sua série, nunca chegam ao fim de seu natural progresso até que atinjam o absoluto: é, portanto, por essa ideia, o ser universal, 
que elas são ordenadas ao ser absoluto. Essa ideia, pela sua perfeita universalidade, tem uma extensão infinita e confere ao sujeito que a possui uma capacidade infinita. Por essa ideia se admira no homem uma singular contradição da natureza, pela qual ele se mostra a nós ora manifestando um ser limitado e ora cresce e aparece como infinito: ele é verdadeiramente um ser misto de finito e infinito, esses dois elementos tão opostos, que ligados e quase mesclados num só formam o homem, explicam aquela perpétua, aquela luta essencial, que apresenta em si a natureza humana que a contempla, pois nada há de mais frágil, nada de mais miserável do que ela, quando é contemplada do lado do sujeito-homem; e nada ao mesmo tempo de mais nobre, de mais excelso, de mais venerando do que ela, quando é considerada do lado do objeto-ser, no qual o homem se admira e se fixa, admiração e fixação das quais nasce a potência visual, a potência, digo, da visão intelectual, entendendo, pois, todas as coisas, por ter conhecido aquela coisa que é a inteligibilidade, a essência e a noção comum de todas as coisas.

Além disso, o mesmo absoluto não pode ser qualquer outro finalmente, como tantas vezes dissemos, senão aquele mesmo ser universal, que põe em ato o pensamento, mas não mais no estado de possibilidade, como ora está na mente humana, e sim no estado de perfeita atualidade: nesse estado, no qual estaria na mente, quando a mente visse o ser não inicialmente, como ora o vê, mas completamente, com o seu término e, portanto, na sua subsistência: então, ela seria perfeitamente saciada, exaurida e vencida, ela veria Deus.

Se desse Ser absoluto e infinito, portanto, ao qual o sujeito inteligente é ordenado, deriva no mesmo a dignidade de que falamos, que o eleva sobre todo o universo sensível; se é quando o homem se considera nessa relação que ele se engrandece, que dela adquire uma espécie de excelência divina; se tal é o fím e o escopo último da natureza inteligente e quanto há nessa natureza de último, que não deixa ir além o pensamento, não convém procurar coisa melhor para a vontade; é claro que o homem não é um fim em si mesmo, mas decerto o fim está nele delineado e, para melhor dizer, iniciado o fim do homem; e é sob esse aspecto que se dá à natureza humana a natureza de fim, isto é, porque ela contém em si o princípio do supremo fim; e é então quando a esse melhor do homem, a essa última alteza se volta o amor dos homens, que esse amor é perfeitamente bom, perfeitamente moral, pois então se ama o ser e ele é amado na sua ordem e é amada completamente a ordem do ser, pois a ordem do ser não é completa senão quando ascende ao princípio da própria ordem, ascendendo àquele ser no qual e pelo qual são e estão todos os seres. 
$\underline{\text { Nota }}$

(8) N.A. Não queremos dar aqui uma definiçãa exata e completa da personalidade, como o fizemos em Antropologia morale. 


\section{Artigo IX}

\section{Dupla dignidade do bem moral}

O que dissemos até aqui explica aquela dignidade que em todos os tempos e para todos os povos foi atribuída à moral, aquela alteza em que sempre foi considerada a justiça e a honestidade, aquela autoridade que essas noções mantiveram mais firme que todas as opiniões sobre os homens, mais forte que todos os interesses, indelével, independente de todas as coisas e sobre todas elas sublime.

Consideremos, primeiro, tanta dignidade na teoria moral e, depois, na prática, ou seja, no ato de quem age de acordo com a honestidade.

Na teoria, a razão dessa dignidade é dupla: nasce do alto princípio e do alto fim da legislação moral, pois essa legislação tem seu princípio no ser mental e tem seu fim no ser absoluto. O ser mental é eterno, necessário, universal, inflexível, não tem nada acima de si; e o ser absoluto é somente o cumprimento, a atuação do ser mental, por isso, é o mesmo ser mental, mas completo, em si subsistente, substância primeira, infinita, Deus.

Na prática, isto é, nos atos moralmente bons, a razão da dignidade e o mérito intrínseco desses atos é igualmente dúplice, isto é, esses atos são assim tão nobres e excelentes porque procedem de um ser inteligente e terminam também na direção de um ser inteligente, porque, como mostramos há pouco, cada ato moral, para ser verdadeiramente assim, deve ser um amor que tenha como seu término um ser dotado de inteligência.

Portanto, a dignidade já anteriormente descrita por nós do autor do ato moral, assim como a dignidade do escopo ou término desse ato são as duas razões pelas quais os atos moralmente bons se tornam tão respeitáveis e venerandos na consciência de todos os povos. 


\section{$\underline{\text { Artigo X }}$}

\section{Aperfeiçoa-se a fórmula da legislação moral}

Ora tratemos de aperfeiçoar ainda mais a fórmula da legislação moral.

Nós a trouxemos, de mão em mão, daquele modo vago e indeterminado em que a princípio se apresentava; com toques quase que sucessivos, aperfeiçoamos seus arredores, demos relevo às formas, fizemos aparecer e sobressair seu caráter.

A princípio, ela soava deste modo: "Segue o lume da razão".

Vimos que o lume da razão é apenas o ser conhecido e que a vontade é a faculdade da moral, aquela que torna o homem autor de suas ações, e pudemos converter essa primeira fórmula em outra mais clara, que diz que "a vontade deve-se inclinar para o ser", ou seja, deve-se amar o ser onde ele for percebido, deve-se amar todo ser porque tal.

Subtraímos, depois de considerar a natureza do ser, e descobrimos que ele tem esse seu caráter intrínseco, a ordem. Portanto, concluímos que quem ama o ser, ama quantos mais seres pode e, com isso, ama ordenadamente. É mediante essa observação que se pode melhorar de novo a fórmula indicada, exprimindo, naquela ordem do amor, aquela ordem necessária, para que o nosso amor seja moralmente bom; e se pode tornála assim: "a vontade deve-se inclinar para o ser segundo a ordem que nele se encontra".

Mas nós finalmente procuramos qual é a ordem do ser e descobrimos que, entre os seres, alguns têm em si a razão de fim e outros somente a razão de meio; aqueles se chamando pessoas e estes se chamando coisas; portanto, vimos como a vontade deve terminar seus afetos naquelas, pois, se ela se permanecesse nestas, seu ato não seria terminado, não seria perfeitamente bom, não seguiria o ser, adaptando-se plenamente a ele, a sua natureza, a sua ordem; mas antes colocaria como fim e término do seu ato o que não é um ser final e último; e com isso chegamos a poder ainda acrescentar um novo grau de perfeição à fórmula moral, acrescentando-lhe essa tendência final da vontade de amar aos seres inteligentes e de não se deter no amor às coisas em vez de às pessoas, isto é, no amor dos seres irracionais.

Finalmente, pusemo-nos a investigar o que é que dá aos seres inteligentes o lugar de fim nas afeições da vontade e fomos elevados àquele elemento divino, incondicionado, infinito, que existe nos seres inteligentes e que neles quer se cumprir, a eles perfeitamente revelar-se na sua subsistência, na sua majestade de Deus; e distinguindo esse elemento verdadeiramente último e verdadeiramente infinito, de todas as outras condições do sujeito que o possui, vimos que a vontade benévola e 
perfeitamente boa deve ter como último ponto de seu movimento esse princípio admirável a um só tempo da inteligência e da felicidade; e que é em relação a esse termo, além do qual não há mais nada, que a vontade deve amar e finalizar o ardor de seu desejo; desse modo, ela ama verdadeiramente o ser como ele é, isto é, ama por si aquele ser que é por si, e ama relativamente ao ser por si todos os outros seres que não são por si, mas pelo ser primeiro e essencial. 


\section{Capítulo V}

De que modo a vontade é a causa do bem e do mal moral

$\underline{\text { Artigo I }}$

O que é a vontade

Dissemos que a vontade é a potência moral; dissemos que o bem, ao ser querido por uma vontade, adquire a denominação de moral, de modo que a moralidade exprime propriamente "uma relação do bem com a natureza inteligente que o quer".

Querer o bem, querer o ser, esse é o ato moralmente bom e, por isso, é esse o ato que ora devemos submeter ao mais diligente exame, tentando conhecê-lo o melhor possível e descrever-lhe a natureza. Até aqui, limitamo-nos a indicá-lo, e o indicamos com palavras um pouco vagas e diversas, expressamos indiferentemente esse ato com as frases: "inclinar-se para o ser"; "amar o ser"; “querer o ser". Devemos agora analisálo, devemos esclarecer e também tornar mais precisas e mais definitivas essas várias maneiras empregadas por nós para exprimir o ato moralmente bom do sujeito dotado de inteligência.

Em primeiro lugar, o que é a vontade? É ela a única potência que o homem emprega? Ou o homem tem alguma outra potência ativa? E, se homem tem alguma outra potência ativa, como a vontade se distingue dessa outra potência?

Para responder todas essas interrogações, basta recordar que o homem tem duas principais faculdades passivas, o sentido e a inteligência; o sentido é a faculdade de perceber as coisas enquanto são subsistentes; a inteligência é a faculdade de conceber as coisas enquanto são possíveis. É próprio da inteligência conceber objetivamente, isto é, conceber as coisas como objetos da mente e, por isso, essencialmente diferentes do sujeito; é próprio do sentido perceber subjetivamente, isto é, perceber as coisas na ação que exercem no próprio sujeito que é por elas modificado.

Mas, a essas duas faculdades passivas, correspondem duas ativas, isto é, ao sentido corresponde o instinto, à inteligência corresponde a vontade. $\mathrm{O}$ instinto move o sujeito a se unir às coisas agradáveis ao sentido e é propriamente a faculdade que preside a felicidade do sujeito (1); a vontade é o sujeito que move a si mesmo (2) a aprovar os objetos conhecidos enquanto são aprováveis, sem relação a si, mesmo que disso possa resultar um deleite puro; e é a faculdade que preside à honestidade, ou seja, ao bem moral. 
A vontade é, portanto, aquela potência ativa pela qual o homem age não impelido por uma inclinação, mas em relação aos objetos da sua mente, age com conhecimento, age segundo a razão que contempla. 


\section{$\underline{\text { Notas }}$}

(1) N.A. Como são dois os sentidos no homem, o corpóreo e o espiritual, assim também são dois os instintos; o primeiro é o que move o homem ao prazer corpóreo; o segundo é aquele que o move continuamente à felicidade.

(2) N.A. É por isso que dizíamos antes que na vontade eleva a personalidade do homem, pois, embora o instinto seja uma potência ativa, não é um sujeito inteligente que com ele opera; é ele que opera no sujeito inteligente. 


\section{Artigo II}

\section{A livre vontade só começa a se manifestar no homem com a reflexão}

Retenhamos, portanto, que a vontade é uma potência ativa que opera segundo razões que o homem tem na mente e que propõe a si mesmo.

Daí decorre que a vontade não poderia operar se não existissem previamente conhecimentos; decorre que essa potência não pode passar ao seu ato, senão com a condição de que o homem tenha adquirido ideias, que se tornam outras tantas razões, segundo as quais lhe é possível deliberar, escolher, querer.

Há, portanto, um conhecimento que precede a vontade, um conhecimento instintivo, isto é, que o homem forma instintivamente para si e não voluntariamente, e esse é o conhecimento direto (3), aquele que depois se torna matéria, ou, para melhor dizer, objeto e escopo da reflexão. $\mathrm{O}$ ato do instinto precede o ato da vontade; o instinto é a primeira atividade, com a qual o homem se move, e é com essa primeira atividade, com esse instinto que o homem tem a percepção e ainda seus primeiros conhecimentos (4). Mas, quando tem em si a memória das percepções e as ideias das coisas, então pode refletir sobre elas voluntariamente, isto é, conduzido a isso não por obra do instinto, mas por um princípio de razão. Se, por exemplo, um homem empreende uma especulação mercantil, pelos grandes lucros que dela espera, vê-se que no empreendimento a sua vontade se move para o lucro; a ideia, portanto, desse lucro é a razão por trás da qual sua vontade atua: deve, pois, tal ideia de lucro preceder ao ato de sua vontade, do contrário ele nunca poderia propô-lo a si mesmo como fim e, não podendo propô-lo a si mesmo como fim, ele não poderia querê-lo, pois se quer algum fim, e aqui está a natureza da vontade de atuar por um fim, de ter por motivo ou razão do seu moto a coisa conhecida, ou como diz a sentença da escola que se tornou comum: voluntas non fertur in incognitum (I).

Ora, quando nos propomos um fim, como seria o lucro, que já mencionamos, o que fazemos? Convém que mantenhamos esse lucro atualmente em mente, de modo que atualmente o queiramos. Mas o que digo é que, se esse manter atualmente em mente o lucro para querê-lo é um ato de reflexão, ele supõe diante de si a ideia do lucro já bela e formada; de outro modo não poderíamos, sem o uso da reflexão, extrair do hábito da memória aquela ideia do lucro em ato, na qual está vivo antecipadamente e na qual miramos, tornando-o um sinal de nossa vontade: em suma, para querer uma coisa, devemos primeiro ter recebido sua ideia, que é o conhecimento direto da mesma, e depois refletirmos sobre ela, para assim fazê-la objeto de nosso querer. 
Não que entre conhecer simplesmente uma coisa e querê-la se encontre tanta diversidade e oposição, que se possa demonstrar deverem ser essas duas operações necessariamente sucessivas e não poderem ser concomitantes; mas é certo que na maioria das vezes são claramente sucessivas; e que sempre, pois, o ato de conhecer é um ato distinto do ato do querer; e que esse ato segundo tem uma tal dependência do primeiro, de modo que o homem não pode querer senão aquilo que conhece; é certo ainda, a quem bem observe como advém o ato de querer, que, quando um sujeito quer alguma coisa, com esse ato, com o qual quer, ele se fixa na coisa que quer como no término do seu querer; ora, esse fixar-se na coisa conhecida é o mesmo que refletir sobre a própria ideia ou sobre a coisa conhecida: o ato da vontade é, portanto, também um ato de reflexão, de uma espécie de reflexão, isto é, de uma tal reflexão que não termina em uma simples contemplação, mas em uma contemplação assentida; de modo que pode haver também uma reflexão com a qual não se queira nenhuma das coisas conhecidas sobre as quais se reflete; mas há também uma reflexão com a qual se termina por querer a coisa; querer, então, está no término, na ponta, quase direi, do ato de refletir, com o qual se olha de novo aquela coisa da qual havia precedentemente em nós a ideia e a memória de sua percepção.

Mas, para melhor esclarecer o nexo estreito que há entre a reflexão e a vontade, devo retornar aqui a uma doutrina que já expus noutro lugar e que é a seguinte.

$\mathrm{O}$ ato da reflexão, com o qual voltamos nossa atenção para as coisas por nós conhecidas, que formam o conhecimento direto, ou produz algo atuando sobre essas coisas conhecidas ou não produz nem atua nada, apenas fixando-se nelas, admirandoas do modo como são, como lhe são apresentadas, nem mais nem menos.

Nesse segundo caso, a reflexão é só um simples restabelecimento ou um reforço da atenção, que não gera nenhum conhecimento novo, mas torna somente mais atual e vivo o conhecimento precedente e direto.

Ao contrário, no primeiro caso, no qual a reflexão atua, isto é, analisa, ou une, ou integra (5) os conhecimentos precedentes e diretos, a reflexão é uma fonte de conhecimentos novos, pois são conhecimentos novos também as formas novas que a mente adquire, os aspectos novos sobre os quais a mente considera os conhecimentos que possui.

Nesse caso, em que a reflexão trabalha e extrai conhecimentos novos da matéria dos conhecimentos precedentes, o término da reflexão é só e propriamente esse 
aumento de conhecimento. No outro caso, em que a reflexão não trabalha os conhecimentos, mas somente se fixa vivamente neles, a reflexão pode terminar o seu ato de dois modos: ou simplesmente olhando de novo para aquelas coisas conhecidas, ou ainda querendo-as, isto é, assentindo voluntariamente a sua verdade e bondade.

Portanto, o ato de vontade é um ato pelo qual o sujeito inteligente reflete sobre uma coisa por ele conhecida (que forma parte do conhecimento direto) terminando com o assentir a ela mesma, isto é, com o reconhecê-la como boa e assim apetecê-la, querêla.

Há, então, três espécies de atos da reflexão: isto é, há uma espécie de reflexão que é apenas uma contemplação imóvel das coisas já conhecidas; esta não produz novo conhecimento nem é uma volição; há uma espécie de reflexão que analisa, une e integra as coisas conhecidas; esta produz novo conhecimento, mas não é uma volição; há finalmente uma espécie de reflexão que, no tempo em que olha de novo um objeto conhecido, dele extrai voluntariamente prazer, dele goza, goza daquele deleite que redunda no ser inteligente quando reconhece plenamente o bem das coisas conhecidas, não colocando obstáculos, antes promovendo em si esse deleite e abandonando-se a ele, ou seja, entregando-se àquela ação agradável, que toda coisa bem querida causa na mente; e esta é uma volição.

Descrito assim o ato da vontade como uma espécie particular de reflexão, e distinto das outras duas espécies de reflexão, a que não compete ser igualmente volições; pode-se perguntar: qual é, pois, a causa da reflexão? Qual é o motivo, o estímulo, pelo qual o homem se agita e passa do não refletir ao refletir?

Respondo que essa razão suficiente que se procura para explicar esse movimento da reflexão do homem é, às vezes, o instinto e, às vezes, é novamente a própria vontade, pois não é absurdo que também a razão do querer seja, às vezes, um ato precedente de querer, já que se pode muito bem querer querer.

A despeito do que começa a nos mover e nos pôr a refletir sobre as coisas por nós conhecidas, o certo é que a conclusão da reflexão, aquele término, aquele juízo último, aquele assentimento, aquele repouso último do espírito, no que consiste essencialmente o ato do querer, depende de nós mesmos: e é por isso que o homem age por sua vontade, porque o ato da vontade é "um ato final, que consuma a reflexão, não que a começa"; e, portanto, é um ato que se faz com conhecimento de causa, porque lhe precede uma reflexão incipiente, que ainda não é ato de vontade; e a volição se 
acrescenta depois ou não se acrescenta, como nos aprouver, como cumprimento e conclusão dessa reflexão, com o acréscimo da qual somente, a reflexão se torna volição. 


\section{$\underline{\text { Notas }}$}

(3) N.A. Falamos longamente do conhecimento direto no Nuovo saggio, vol. 3, págs. 100,130 e 172.

(4) N.A. Nuovo saggio, vol. 2, págs. 94 e segs.

(I) N.T. "Não se tem desejo do desconhecido", cf. Tomás de Aquino, Suma Teológica, I, q. 80, a. 2.

(5) N.A. Ver o que é a faculdade integrativa do entendimento no Nuovo saggio, vol. 2, págs. 188 e segs. 


\section{Artigo III}

\section{De que maneira as ações e os afetos dependem da vontade}

Quando pratico uma ação voluntariamente, então mostro com o fato mesmo, que prefiro praticá-la a não praticá-la, e que me agrada mais esta ação do que aquela outra, entre as quais talvez tenha escolhido e preferido esta. Se ela não me agradasse (não posso ser forçado a praticá-la, porque se trata de uma ação voluntária e não puramente física), eu não a teria praticado; e, se eu tivesse tido presente outra ação qualquer, a que tivesse dado o meu afeto, é claro que teria praticado esta última ação no lugar daquela outra. Sobre isso não pode ficar nenhuma dúvida: a mais simples observação é suficiente para nos convencer disso. Mas o que nos prova esse fato? $\mathrm{O}$ que nos diz uma tal observação sobre o nexo estreito entre as ações e os afetos?

Esse fato nos revela uma verdade importante, a de que nós agimos sempre segundo um certo amor em nós predominante aos outros amores. Em verdade, seria totalmente absurdo pensar que deixássemos de lado o que mais amamos, o que nos é mais caro, para fazer aquilo que menos amamos e nos é menos caro. Em todos os casos sem exceção ocorre isto: nossa ação é sempre o verdadeiro sinal, a verdadeira expressão do nosso amor, porque ela é também de algum modo um efeito desse amor. De modo que, digamos também, se fôssemos moralmente forçados a fazer algo que nos desagrada (digo moralmente, porque as ações da vontade não são sujeitas a uma violência mecânica, nem a uma necessidade mecânica), se fôssemos forçados a fazê-lo pelo temor de males graves; não seria igualmente verdadeiro que aquela obra que faríamos em tal caso decorreria de um afeto predominante? Claro, não falo já de um temor que perturbe a mente e impeça o conhecimento, pois um temor assim, impedindo o conhecimento, tornaria impossível um ato da vontade, deixando somente o instinto em condições de atuar. Mas, fora esse caso, porque pertence a outra questão, e falando somente do homem, o qual age com a eficácia da vontade, digo que, quando o homem age com a sua vontade, ele natural e necessariamente age segundo o amor que nele predomina sobre outros amores no ato do seu agir; e que seria absurdo pensar o contrário, sejam quais forem as circunstâncias, faça o homem até aquilo que não queria, por temor de males graves; o fato ocorre sempre assim. Pois, mesmo nesse último caso, o que ele faz é o que ele reputa o menor dos males e o menor dos males, comparado aos maiores males, é um verdadeiro bem e o bem é aquilo que se ama. Se, portanto, o homem é constrangido por maiores males, que ele teme, e, para fugir deles, escolhe o mal menor, ele não o faz porque isso que escolhe é um mal, mas porque isso é um meio que o libera 
de males maiores, um meio que o afasta daquilo que mais teme; é algo para ele, sob esse aspecto, amável, ainda que por outras causas o desagrade.

Devo também observar que o amor predominante que seguimos com nossas ações não é qualquer amor, mas uma amor de índole própria, dotado de caracteres próprios, quer dizer, não é um amor especulativo, mas um amor prático; não é um amor geral, mas particular, no qual consideramos a ação que devíamos praticar em todas as suas particularidades; não é um amor habitual nem também necessariamente durável por um longo espaço de tempo; mas é um amor atual, que não tem necessidade de durar mais do que um instante, isto é, não mais do que aquele instante que imediatamente precede a ação e que a determina. Verdadeiramente, observando-nos a nós mesmos constataremos que, por um amor instantâneo, somos levados a praticar ações a que talvez pouco antes se condenassem a si mesmas ou que, uma vez praticadas, nos causam dor ou arrependimento. Quantos não poderão dizer com os amantes do poeta:

"Ma solo un punto fu quel che ci vinse"? (I)

E por que isso, senão porque aquela vivacidade do amor durou somente aquele instante no qual a ação foi deliberada, e bastou aquele fugidio instante para que o homem passasse a agir? E porque a acuidade daquele ato de amor talvez cessasse imediatamente depois e voltasse a prevalecer no homem um outro amor, por isso o homem revela-se frequentemente um mistério a si mesmo, um inexplicável mistério, uma contradição perpétua, pela qual quer e não quer a um mesmo tempo; contradição que gera mais espanto e maravilha, quanto mais o ato de amor com que se praticou a ação, antes odiada, foi breve e fugidio e, portanto, dificilmente pôde ser advertido, não se deixou bem conhecer, bem examinar, revolvendo e escondendo em si aquelas muitas, mas velocíssimas gradações, nas quais a paixão despontou, fermentou, fortaleceu-se e chegou a sua plenitude, àquele término em que, se o homem não lhe opõe prontamente outro amor, ela já busca a passagem para expandir-se exteriormente, já move as potências operativas, que começam, avançam e consumam as ações exteriores.

Pode-se, portanto, estabelecer sem medo de errar que onde o amor se tornasse de tal modo atualizado, predominante e tão próximo da ação quanto necessário a produzi-la; e ainda quando, por suposição, esse amor não pudesse mais mudar ou declinar, nem pudesse ser sobrepujado por outro amor naquele intervalo que corre entre ele incipiente e a ação consumada; esse amor produziria a ação necessariamente e o homem, em tal caso, se veria privado de sua liberdade, ou, para melhor dizer, já teria concluído irrevogavelmente o ato dessa liberdade. 
Mas se ora todas as ações dos seres morais se praticam mediante um ato de amor predominante, que chamarei de amor prático, e se, dado esse ato, a ação deve necessariamente se seguir, mas, se por outro lado o homem é livre, onde, pois, se pode procurar essa sua liberdade? Em que consiste a livre vontade do homem? Consiste ela nas ações ou consiste propriamente no formar e determinar o amor, só com o qual produz as ações, agente moral que ele é?

Não pode consistir em querer as ações independentemente do amor às mesmas, pois seria uma contradição querer as ações sem amá-las. Portanto, se somos livres para querer ou não querer as ações, assim o somos por sermos livres para amá-las ou não amá-las, porque somos livres de aumentar ou diminuir o nosso amor ou o nosso ódio para com essa ou aquela ação ou omissão. Essa nossa potência que se chama liberdade, exercita-se primeiramente sobre os afetos do nosso coração e só por conseguinte se exercita depois sobre as próprias ações, sendo essas indivisivelmente ligadas aos afetos; em suma, nossas ações são livres, mas na liberdade dos afetos.

Estabelecido essa importante verdade, que somos senhores de nossas ações unicamente porque somos senhores de nossos afetos, resta ver se a sede própria de nossa liberdade são os afetos. Somos livres, portanto, sem mais de uma liberdade que se refere ao domínio de nossos afetos imediatamente? Ou antes dos afetos há talvez outra operação em nosso espírito da qual nossos afetos dependem, como vimos depender deles nossas ações exteriores?

Consideremos atentamente a natureza dos afetos humanos, a natureza do amor e do ódio. Vejo que não posso odiar uma coisa se não a considero má, porque é impossível que o bem seja causa de ódio em mim; ao contrário, vejo que não posso amar uma coisa, se não a considero como bem, porque é impossível que o mal seja causa de amor em mim. É verdade, no entanto, que posso amar até as coisas que me são nocivas e que são más; porém não posso, contudo, amá-las, senão com a condição de que eu as considere agradáveis sob algum aspecto e que, sob esse aspecto, eu as considere boas. Igualmente, posso odiar coisas que me são úteis e boas, mas somente com a condição de que as considere como desagradáveis e más. Não é a coisa como é em si mesma que me suscita o amor ou o ódio, mas é a coisa como eu a considero e penso, como a julgo: a coisa poderá ser boa, mas se eu a julgo e considero má, ela produzirá aversão em mim; a coisa poderá ser má, mas se eu a julgo e considero boa, criará em mim propensão e amor. Portanto, diziam os escolásticos, que o mal só pode ser amado pelo homem sub specie boni, frase que, como tantas outras, passou da 
escolástica ao falar comum dos homens, porque exprimia exatamente um sentimento comum.

E verdadeiramente convém pensar que o amor é afeto de um ser inteligente; por isso, um afeto que se dirige a um objeto conhecido, a um objeto que mostra à mente seus méritos e a faz admirá-los e amá-los. Portanto, é na intrínseca natureza do amor, que não deve ser confundido com um instinto material e cego, que se contém a estimativa (II). Quem ama um objeto, deve primeiramente estimá-lo; amando-o, ele mostra o fato de estimá-lo, de reputá-lo agradável, bom e digno de amor; ama-o não por outro motivo, senão porque antes o estima, porque primeiramente o jugou dotado de valores e de qualidades amáveis. Pode bem acontecer que, enquanto amo um objeto, conheça também os seus defeitos, mas esses não são o escopo ou a causa do meu amor. Deve haver algum valor, senão verdadeiro, pelo menos aparente, que, no ato do meu amor, vence e enfraquece ou desgasta ou impede a aversão que aqueles defeitos produziriam em mim e, no lugar dela, desperta e infunde um amor em mim. Será também talvez momentâneo esse ato, como dissemos, será desaprovado por mim mesmo; mas naquele ato em que amei predominantemente aquele objeto, encontrei uma forte razão de amá-lo, vi nele uma qualidade que me atingiu mais do que qualquer outra coisa e que me cegou para todas elas; eu o estimei, enfim, amável e tal que deveria me ser caro; por um só instante, fugidiíssimo, sim, fui dominado por uma tal ilusão; mas até naquele instante devo ter sido tomado pelo amor (se é amor e não transporte irracional), devo ter tido uma estima, ter sido persuadido de que havia um valor vívido e agudo, e esse valor arrebatou, por assim dizer, o afeto de meu coração.

Há, pois, uma estimativa que precede proximamente o amor e que o produz, há um juízo sobre os méritos, sobre a amabilidade da coisa, que é o que caracteriza o amor como ato de um ser inteligente e o distingue das propensões animalescas, as quais não excedem os limites da sensibilidade corpórea e nada têm de livre; chamarei a essa estimativa, para distingui-la de qualquer outra espécie de estimativa, de estimativa prática; chamarei esse juízo, juízo prático; compreendendo com essa palavra prático uma espécie de juízo sobre os valores das coisas percebidas, que precede imediata e necessariamente o afeto e que é a causa eficiente do afeto ou a condição do afeto.

O amor prático é, portanto, produto da estimativa prática, que não se deve confundir com a estimativa especulativa, a qual sói nascer de razões gerais e constantes, enquanto aquela resulta de todas as razões mais particulares e talvez fundada sobre fenômenos momentâneos. Para que se acenda, o amor tem sempre necessidade, antes 
de si mesmo, dessa estimativa. Do contrário, onde se faz essa estimativa prática, onde esse juízo prático é por nós concluído, o amor não pode faltar, ele desponta necessariamente dessa estimativa, é quase uma continuação, um sentimento dela. Há, portanto, uma lei imutável e de todo independente do arbítrio do homem, que une o amor e a estimativa, uma lei semelhante àquela acima descrita, que une as ações exteriores e o amor. O homem pode aumentar ou diminuir o seu amor por um sujeito, mas com a condição de que ele aumente ou diminua sua estimativa prática do mesmo: pode exercitar a sua potência da livre vontade sobre o amor, mas mediante a estimativa. Portanto, é porque ele pode aumentar ou diminuir em si mesmo a estimativa prática das qualidades de um objeto, que ele pode igualmente diminuir ou aumentar o seu amor, pois, aumentada ou diminuída aquela, este também aumenta ou diminui, pelo vínculo que tem com ela, vínculo íntimo, essencial, semelhante àquele entre um efeito e sua causa.

Não é, portanto, nem sobre os próprios afetos, sobre o amor e sobre o ódio, que se exercita imediatamente a liberdade do homem; mas o objeto primeiro, imediato e próprio dessa liberdade é a estimativa ou o juízo prático que o homem leva aos objetos contemplados por sua mente; e é nesse primeiro ato que convém procurar a natureza e as leis da livre vontade. É, pois, necessário submeter a um diligentíssimo exame esse ato, com o qual o homem, refletindo sobre os objetos de sua mente, faz uma estimativa, ou seja faz um juízo prático dos mesmos; é isso que nos propomos a fazer aqui.

Já distinguimos o conhecimento direto do conhecimento reflexo, e vimos que aquele é necessário e este voluntário. Ora, o juízo prático de que falamos é somente um ato propriamente da reflexão, que se desdobra sobre as coisas que já foram percebidas e das quais, por isso, se têm as ideias e sobre as mesmas se ajuíza. Todo o processo dessa operação do espírito volitivo requer de nós a mais diligente observação e eis os resultados que a observação me parece justamente fornecer.

O conhecimento direto não é voluntário, mas necessário.

A razão disso é que o conhecimento direto consiste nas primeiras ideias que se adquirem das coisas. Ora, antes de adquirir essas ideias, não temos nenhum interesse que nos impulsione a querê-las de preferência de um modo que de outro, justamente porque ainda não as conhecemos. Percebemo-las, portanto, tais como se apresentam, percebêmo-las não com deliberação, mas instintivamente, passivamente. A título de exemplo, antes que eu faça a ideia de homem, não posso estimar esse ser nem muito nem pouco, julgá-lo a mim agradável ou desagradável, nem contrário ou favorável a 
mim; não posso, portanto, ter nenhum interesse de que aquela ideia me venha de preferência de um modo ou de outro, recebo-a como ela é. Mas, depois, quando sei o que é homem, quando formei essa ideia de homem, então posso estimá-lo pouco ou muito, encará-lo como um ser bom ou mau, digno de amor ou de ódio. Devo, pois, ter primeiro a ideia dele e depois posso fazer esse juízo: e a ideia constitui propriamente o conhecimento direto, que não é nem pode ser sujeito à minha vontade e assim não pode ser a fonte de minha moralidade.

Mas, dada a ideia de uma coisa, dado o conhecimento direto, então a reflexão que faço sobre ela pode ser de todo voluntária; posso fazer juízo da mesma com toda deliberação. Posso ainda conduzir essa minha reflexão até a um certo fim, a um resultado de acordo com a minha vontade.

$\mathrm{Na}$ ideia da coisa (conhecimento direto) concebi o ser da coisa; sendo o ser o mesmo que o bem, concebi igualmente o bem e o fundamento do bem. Para que eu possa destacar expressamente a quantidade de bem de uma coisa, basta que eu destaque a quantidade de ser; quantidade de ser já que conheço necessariamente em si, tendo concebido com conhecimento direto aquele ser, aquela coisa. Onde eu queira destacar e dizer a mim mesmo que coisa é essa que concebi, quanto de ser ela tem, quanto de boa seja a coisa de que tive o pensamento, basta que reflita sobre essa coisa por mim conhecida e não dissimule para mim mesmo isso que ela é, isso que eu já sei que é, mas reconheça aquilo que já conheço. Esse reconhecimento pleno e inteiro disso que já conheço, dos objetos já por mim captados, é um ato imediatamente sujeito à minha livre vontade, é aquele em que se inicia o ato moral, em que esse se forma, e que é depois seguido pelo amor e pela ação exterior assim como vários outros de seus efeitos.

Mas, para evitar qualquer equívoco e confusão ao descrever uma operação tão importante do espírito humano, e direi ainda tão esquiva à observação, convém observar a diferença que há entre o efeito da sensação e o do conhecimento direto: a sensação produz em nós uma propensão instintiva aos objetos sentidos ou uma aversão; ao contrário as ideias, por sua natureza universal (6), são frias ou produzem somente um deleite incipiente, uniforme e que terminaria imediatamente, se a reflexão da vontade não viesse sobre aquelas primeiras ideias e não extraísse delas um deleite voluntário, contemplando-as, olhando-as fixamente, admirando os valores dos objetos que nelas se pensam, para sentir sua eficácia e obter o gozo intelectual delas.

E, verdadeiramente, não é a primeira ideia da coisa que produz um vivo deleite; mas a reflexão, a admiração da mesma nos enamora. Ora, esse fixar-se com a reflexão 
em um objeto conhecido para sentir-lhe os méritos, esse admirá-lo é um ato voluntário do espírito, com o qual ele ilumina para si mesmo o objeto, percebe-o mais vivamente, adaptando-se, quase direi, para receber melhor a impressão daquela espécie e, assim, em razão da luz que aumenta sobre aquele objeto e sobre seus méritos, se é nos méritos que mais a reflexão se fixa, a vontade atinge um grau sempre maior de deleite e esse deleite, crescendo, se torna um verdadeiro enamoramento, enamoramento esse seu que se eleva a um grau sempre maior. Sendo, portanto, todas as ideias primeiras com as quais conhecemos as coisas igualmente frias e nos enviando uma luz ainda tênue e comedida, a vontade permanece perfeitamente livre e o primeiro ato dessa vontade tem por escopo ou reconhecer os valores da coisa ou desconhecê-los. Se a vontade se move a fim de reconhecê-los, ela se fixa com a reflexão na coisa conhecida e com esse fixarse faz os valores da coisa operarem vivamente sobre ela, desvelando-se em um lume mais vivo e dominante, claro e agradável lume a que pronuncia um juízo prático favorável, que é seguido pelo amor e as ações conformes. Mas, se a vontade se move a fim de desconhecê-los, ela ou só olha ligeiramente os valores ou olha só os defeitos e os ilumina mais para si mesma, do que nasce a visão de uma deformidade e asquerosidade, que produz um sentimento desagradável, e depois dele um ódio e as ações conformes. O processo de ação da vontade humana, portanto, é o seguinte:

Primeiro, há no homem as ideias e memórias das coisas, conhecimento direto.

Depois, a vontade move a reflexão sobre essas coisas conhecidas e esse movimento é bom ou mau moralmente, isto é, ou se propõe a reconhecer imparcialmente os valores das coisas ou a desconhecê-los e contrapô-los a si mesma.

Ora, se a vontade é boa, isto é, não movida por algum falso interesse, por algum fim secundário, por algum instinto perverso, ela procura somente reconhecer as coisas conhecidas como elas são, nem mais nem menos, de ver-lhes tanto os valores quanto os defeitos sob luz igual; nesse caso, ela se move conforme a natureza, move-se apenas para a verdade, ela não procura nem tornar mais viva a ação dos defeitos, nem a das qualidades, nem um defeito mais que outro, nem uma qualidade mais que outra, reconhece completamente cada parte da coisa como ela está, não a distorce, ama-a toda, ama todo o ser que encontra nela e não mais do que isso que encontra.

Se a vontade é má, não tem por fim a verdade, mas, movendo-se por um mau instinto (7), fixa a reflexão parcial e injustamente sobre os objetos da mente (conhecimento direto). Nesse caso, ela se move de modo a produzir uma dessas desordens, isto é, ou recebendo uma ação dos defeitos mais forte do que conviria, ou 
seja, desproporcional, ou recebendo uma ação dos valores mais forte do que conviria; no primeiro caso, desperta-se nela um ódio irracional e injusto; no segundo, um amor irracional e injusto.

Para nascer um ódio irracional, basta que a reflexão voluntária deixe de olhar as qualidades da coisa e ocupe-se toda dos defeitos; para nascer um amor irracional, basta que se ocupe só das qualidades, sem atentar aos defeitos. Mas, além disso, a eficácia da reflexão voluntária é tão grande que ainda gera e cria na coisa defeitos que não existem, se ela quer odiá-la; ou, se quer indevidamente amá-la, cria valores inexistentes. Essa eficácia da vontade é um fato de grande importância, nunca suficientemente considerado.

No entanto, do que se disse resulta que, quando se põe a refletir sobre os objetos percebidos, a vontade é perfeitamente livre e pode reconhecer simplesmente as coisas conhecidas por conhecimento direto, porque as tem na mente, e também pode desconhecê-las: no primeiro caso, é boa e, no segundo, má. Esta bondade e esta maldade moral está, portanto, propriamente na primeira direção voluntária da reflexão, e ali tem sua sede e a sua fonte. É por isso que o autor do Evangelho escreve: "Se teus olhos forem simples, todo teu corpo será lúcido, mas se teus olhos forem iníquos, todo teu corpo será tenebroso" (Lc. 11, 34), porque é dos olhos da alma bem sadios, é do ver puro e franco da vontade que nascem os afetos e as ações não tenebrosas, mas dotadas de perfeição e luz. E, de fato, é nesse ato da reflexão que a vontade se leva ao seu movimento de modo reto ou torto: ela se fixa no que quer e se fixa para produzir em si mesma uma viva apreensão da qualidade ou do defeito das coisas. Daí essa viva apreensão ser verdadeira ou falsa, pois ela vê, se quer, mesmo o que não há na coisa, como também não vê, se não quer, o que na coisa há; tal eficácia ela tem. Essa viva apreensão do bem e do mal da coisa fecha-se depois com o juízo prático ou estimativa da coisa, ou seja, com o reconhecimento fiel ou infiel do que é percebido no conhecimento direto: aqui está o consenso moral.

Feito esse reconhecimento, juízo ou estimativa prática, então surge imediatamente o prazer vivo, se aquela viva apreensão foi do bem, ou o desprazer também vivo, se foi do mal. Aquele prazer é o início do amor, o qual se forma imediatamente quase como cumprimento e fim de tal deleite. Aquele desprazer é somente o princípio do ódio, que se suscita como continuação daquela pena, da qual é o selo e o fim.

Após o amor e o ódio, segue a ação. 
Antes que o ser moral passe à ação exterior ocorre um trabalho secreto no seu espírito, que se compõe de mais passos, que são os seguintes: 1) apreensão das coisas ou conhecimento direto; 2) reflexão voluntária sobre as mesmas, reta ou perversa, segundo tenda a reconhecer fielmente o conhecimento direto ou a alterá-lo; 3) meditação, nome com o qual quero indicar apenas os momentos mais ou menos longos nos quais a reflexão voluntária se fixa sobre o conhecimento direto; 4) apreensão viva e operante, produzida pela meditação, a qual resulta verdadeira ou falsa, segundo tenha sido reto ou ruim o ato da vontade que dirigiu a princípio a reflexão a meditar; 5) juízo ou estimativa prática, efeito da apreensão viva e seu cumprimento; 6) deleite intelectual ou dor, efeito do juízo prático; 7) amor prático; 8) atos exteriores.

Essa é a série das operações ou, antes, dos estados sucessivos de um ser moral que age exteriormente: a ação exterior é somente o último desses sete graus que enumeramos e analisamos, sendo o primeiro deles o conhecimento direto, que é imune à eficácia da vontade ao formar-se, mas que dá fundamento a todo o edifício moral, porque fornece à própria vontade a matéria sobre a qual movimentar-se e exercitar a sua atividade.

Embora eu entenda que qualquer homem que se recolha atentamente em si mesmo não possa deixar de reconhecer a verdade do processo do ato moral por mim descrito, todavia não será inútil que eu aponte aqui uma dificuldade que facilmente se poderia apresentar à mente. Porventura não se entenderá como a reflexão voluntária, fixando-se sobre as coisas conhecidas, possa criar algo que nelas não há ou não ver aquilo que há. Pode parecer, à primeira vista, que não somos livres no conhecimento e que não podemos deixar de ver as coisas como as percebemos. Essa objeção desvanecerá facilmente no ânimo daquele que atentamente observar o fato do conhecimento como foi por nós descrito.

É verdade que se percebem as coisas tal qual se nos apresentam, mas essas percepções das coisas formam propriamente aquilo que chamo de conhecimento direto. Nós o declaramos também imune à influência do arbítrio e anterior ao uso da liberdade humana.

Mas, quando já não se trata mais de conhecer as coisas, mas de reconhecê-las, isto é, de refletir sobre as coisas por nós já conhecidas, e ver-lhes o valor, o bem que têm em si, a sua amabilidade, é então que nossa vontade se manifesta livremente e tem tanta eficácia, que pode alterar o seu conhecimento e formar juízos falsos sobre as coisas percebidas, dando-lhes qualidades que não têm ou defeitos e males que também 
não têm. É assim que sempre nasce o erro nas mentes humanas: o erro é efeito da reflexão e de uma reflexão voluntária; de outro modo o erro seria inexplicável; e, dessa verdade, de que a vontade seja a causa do erro já fiz noutro lugar um longo tratado (8).

Convém pensar que o homem não apenas raciocina, mas crê; crê em si mesmo, crê nas suas paixões: se quiser, forma uma persuasão totalmente artificial; é essa eficácia da vontade de propor coisas a si mesma e de nelas crer que dá lugar à primeira injustiça de que falamos, aquela injustiça interior que é a essência de toda injustiça e de toda imoralidade.

Por que, afinal, uma mesma coisa é as vezes julgada tão diversamente pelos homens? Talvez porque a percebam diversamente? De jeito nenhum: a percepção da coisa é igual em todos, todos chamam aquela coisa pelo mesmo vocábulo e, quando pronunciam esse vocábulo, entendem muito bem que coisa eles querem de comum acordo significar: isso prova que o conhecimento direto é igual em todos. Mas um juízo reflexivo se segue e esse juízo varia nos diversos sujeitos que o formam; é esse juízo que dá um resultado para este e outro para aquele, de acordo com as disposições particulares, conforme a vontade diversamente inclina.

É verdadeiramente singular escutar em época de combates políticos como os próprios fatos se alteram e são entendidos diversamente de acordo com quem quer entendê-los. Não estou me referindo a fatos que se inventam de maneira escancaradamente mentirosa: com essas invenções deliberadas não se busca enganar a si mesmo, mas aos outros. Falo daqueles juízos com os quais primeiramente o homem busca a enganar-se a si mesmo, falo daquela facilidade de dar crédito a rumores vagos, favoráveis às próprias esperanças e às próprias opiniões; daquela extrema dificuldade de dar crédito a notícias contrárias, ainda que bem fundamentadas; daquele exagero perpétuo, do qual um evento desejado é sempre estimado muito maior que o verdadeiro e um acontecimento desagradável se atenua e apequena; daquela atenta vigilância em certas coisas e daquele esquecimento de certas outras; daquela agudeza, que de um fato recolhe, releva e predica todas as minuciosas circunstâncias que agradam e imagina também aquelas que possam ser de algum modo verossímil; e daquela obtusidade voluntária em que se ignoram, negligenciam e se deixam de lado todas aquelas que desagradam.

Quanta sutileza de engenho para persuadir a si mesmo que tudo vai bem! Quanta estupidez a respeito de coisas que até de si mesmos querem esconder, das quais temem ir a fundo, evitando delas fazer uma viva impressão! Em suma, quais juízos opostos, 
quais estimas diversas de um mesmo fato conhecido igualmente por duas pessoas, mas de partido contrário, de um fato que ambas as pessoas ouviram provavelmente de uma mesma boca, escutaram talvez contar com as mesmas circunstâncias e revestidas das mesmas expressões! O conhecimento primeiro desse fato, decerto, foi nos dois o mesmo: esse conhecimento direto não pôde, ao ser primeiramente recebido, sofrer a ação da sua vontade. Mas, recebido esse primeiro conhecimento, logo a vontade desencadeia a reflexão sobre ele e começa a tomar partido: então, aqueles dois homens se dividem, pronunciam sentenças tão diversas sobre a mesma notícia: um deles estima o fato importante porque lhe é favorável, enquanto o outro o estima de nenhuma importância porque lhe é contrário; então, todas as gradações das coisas ficam por conta da prevenida e apaixonada vontade; e, enquanto um, a título de exemplo, narra que, num cerco, não pequeno foi o número dos mortos da parte dos sitiantes, o outro conta que o número foi grandíssimo, enorme; quando, se porventura tivesse ocorrido o contrário, aquele mesmo número que para um é grandíssimo, imenso, se tornaria apenas grande, ou não pequeno, ou ainda menos. Falo em um número, porque creio supor conhecido de fato um número preciso; quero crer que nenhum dos dois ignorasse que eram por hipótese dez mil. O conhecimento do número era, portanto, igual, mas a estimativa daquele número quão diversa! Já que esses dez mil perdidos é uma derrota irreparável de acordo com um deles e, para o outro, é somente uma pequena perda, que brevemente será ressarcida com esses e aqueles reforços; com esses e aqueles reforços, digo, que um vê claramente, mas que para o outro são perfeitamente invisíveis. É possível que a disparidade de tais juízos dependa do grau de conhecimento e de previsão daqueles que o fazem? Talvez, mas a experiência costuma mostrar o contrário. Pois aconteça um evento oposto e a lógica que estava na cabeça de um imediatamente passa a estar na cabeça do outro, trocam-se os argumentos; aqueles que o adversário usava e que o outro escondia, ou de que não se importava ou julgava ineptos e tolos, são agora os que parecem a este evidentes e incontestáveis, mas a que o primeiro já apresenta muitas e muitas exceções, ou não os admite nem muito nem pouco. Mas como, não os terá usado ele mesmo? Não se recorda mais deles e, além disso, as circunstâncias eram muito diferentes; e aqui se exibe nova sutileza de engenho para ressaltar todas as diferenças de circunstâncias, diferenças que de resto simplesmente não existem. O que demonstram, enfim, todos esses debates é que se geram persuasões contrárias nos ânimos de duas pessoas não porque a coisa que julgam e em torno da qual a persuasão se forma não seja percebida igualmente por ambas, ou porque uma pessoa seja 
realmente mais esperta do que a outra, mas sim porque querem ter sobre a mesma coisa uma opinião, um juízo, uma persuasão diversa.

Portanto, o homem que tem uma vontade má tem duas medidas; com uma mede as coisas que lhe são favoráveis, com a outra as desfavoráveis; e essas duas medidas provam a eficácia da intervenção da vontade: não é a parte de conhecimento necessário que erra, é a parte do conhecimento voluntário, conhecimento reflexo, conhecimento que consiste em um juízo, em uma persuasão artificial, em uma crença. 


\section{$\underline{\text { Notas }}$}

(I) N.T. Dante Alighieri, La Divina Commedia, Inferno, canto V, v. 132. "Mas um só ponto foi que nos venceu". (Tradução minha, pois nas versões em português do poema, as paráfrases da estrofe em que o verso aparece, muitas vezes, o transformam completamente.)

(II) Estimativa: assim traduzi o italiano stima, pois é nesse sentido que Rosmini emprega a palavra, ao passo que estima, em português, traria ambiguidade sobre o sentido do termo, podendo significar tanto cálculo (estimativa) quanto afeição (estima). (6) N.A. A ideia da coisa é a intuição da possibilidade da coisa: a possibilidade da coisa é fria por natureza: um alimento possível não sacia a fome e de nada interessa ao faminto. O mesmo se pode dizer de todos os outros bens meramente possíveis.

(7) N.A. Ação da vontade ocorre sempre que o homem age por um fim conhecido. Todavia, ele pode ser movido para esse fim também por um instinto. Assim, a vontade e o instinto se entrelaçam e agem muitas vezes conjuntamente.

(8) N.A. Ver o Nuovo saggio, vol. 3, págs. 188 e segs. 


\section{Artigo IV}

\section{O "reconhecimento" do ser que conhecemos é o princípio da justiça}

Possuímos, portanto, uma energia interior que faz uma estimativa arbitrária dos objetos conhecidos, que produz em nós uma persuasão, que nos impõe uma crença acerca deles, e é essa a função própria da vontade.

A estimativa é seguida pelo afeto e, sendo aquela voluntária, é voluntário este também; o afeto é seguido da ação exterior, e, sendo aquele dependente da vontade, assim também esta é; a estimativa é livre por si mesma, essencialmente; o afeto é livre na liberdade da estimativa; e a ação exterior é livre porque participa da liberdade do afeto, da qual necessariamente depende.

Essa persuasão e estimativa que formamos em nós mesmos com a eficácia da nossa vontade reflexiva é racional, se é coerente com o conhecimento direto que temos da coisa acerca da qual essa persuasão se forma; é irracional se não é coerente com o conhecimento direto, mas dele se priva e separa: em tal caso, ela é totalmente criada por um esforço da nossa eficácia interior, é uma persuasão imaginária, artificial, arbitrária, o que vem expresso no mote comum stat pro ratione voluntas (I). Daí que o erro é todo individual, todo de nossa produção; é por isso que no erro o orgulho humano tanto se compraz, porque sente, ao produzi-lo, que é obra sua, que ele despende uma energia maior para formar o erro do que para simplesmente reconhecer a verdade; esse uso maior da própria potência que o homem faz no erro é aquele título infeliz, em que tantos procuram uma glória tristíssima e tantos se dão.

Essa persuasão de que falamos é sempre um juízo, pois o persuadir-se de que um objeto tenha, a título de exemplo, tanto e tanto de bem ou de valores em si, é um julgar dentro de nós que a coisa seja assim; e esse juízo, como dizia, é verdadeiro ou falso, conforme esteja de acordo e corresponda ao conhecimento direto da coisa, ou dessa discorde e se diferencie. O resultado desse juízo é a estimativa da coisa, estimativa que, para repetir uma vez mais, é justa ou injusta, segundo seja ela proporcional ou não à ideia ou conhecimento direto da coisa acerca da qual se pronuncia. Racionalidade da persuasão, verdade do juízo, e justiça da estimativa são sempre a mesma coisa, no fundo, exposta em três relações diversas, em três modos diversos.

Ora, portanto, no que consiste, afinal, o ato moralmente bom, o ato primitivo honesto e justo?

Consiste em reconhecer aquilo que primeiro conhecemos. 
Conhecemos as coisas: esse é o conhecimento direto e necessário; nós as reconhecemos: esse é o conhecimento reflexivo e voluntário. No conhecimento direto, concebemos aquela coisa e, logo, aquele ser, todo o ser que há naquela coisa. Se nós, refletindo, reconhecemos tudo aquilo que há naquela coisa, nesse caso relevamos o grau justo e verdadeiro da sua bondade, mas se dissimulamos para nós mesmos qualquer parte do seu ser, que, no entanto, em nossa mente é concebido, em tal caso lhe fazemos mal, em tal caso mentimos para nós mesmos, em tal caso julgamos que ela tem menos bem do que realmente tem e que nós sabemos que tem, mas não queremos sabê-lo. Uma mesma injustiça cometemos, uma mesma mentira pronunciamos para nós mesmos, quando, em vez de reconhecer aquela quantidade de ser e de bem que se compreende na ideia que temos da coisa, nós colocamos voluntariamente nela, arbitrariamente, mais do bem e, vejamos, ou dizemos a nós mesmos ver aquele bem que na coisa verdadeiramente não há e que verdadeiramente não vemos.

Há, portanto, dois conhecimentos em nós, os quais ou estão de acordo entre eles e, em tal caso, há no homem a veracidade e a justiça; ou estão em discórdia um do outro, e, em tal caso, há no homem a mentira interior e a injustiça.

O segundo conhecimento do homem, se é verdadeiro e bom, consiste em um assenso que dá a vontade ao conhecimento primeiro da coisa, numa quietude, num repouso em que a vontade se deixa estar de bom grado, quase se fia no conhecimento primeiro e espontâneo: assim habita no homem a verdade e, filhas da verdade, a tranquilidade e a paz. Mas, se o segundo conhecimento do homem é falso e mau, ele consiste em uma hostilidade que a vontade faz contra o conhecimento, num dissenso que ela dá indevidamente ao conhecimento, com o qual nega reconhecê-lo, em uma rebelião contra a verdade, em um presunçoso e ultrajante esforço, em que, em vez de reconhecer aquilo que conhece, no lugar de admitir as coisas como são na própria mente, procura mudar o próprio ser das coisas, fazer com que as coisas sejam por si diferentemente daquilo que são, de combater o conhecimento verdadeiro, legítimo, natural, e substituí-lo por uma máscara de conhecimento, falsa, artificial, contra a natureza: há, enfim, uma luta entre o verdadeiro e a vontade que não o quer verdadeiro, e não pode todavia impedi-lo de ser verdadeiro.

Por essas observações se explica porque a persuasão do erro não é nunca tão forte quanto a persuasão da verdade. Na persuasão do erro, permanece sempre, no fundo do homem, algo que repugna, que continuamente contradiz o erro, isto é, permanece o 
conhecimento direto, que jamais se pode extinguir em nós, senão na condição de cairmos em total ignorância das coisas.

Explica-se porque a alguns homens os argumentos mais fortes causem, em certas circunstâncias, pouca ou nenhuma impressão e pululem na sua mente infinitas dúvidas vãs sobre as coisas mais evidentes; enfim, explica-se porque, como diz o texto evangélico, "aqueles que veem, não enxergam; e aqueles que ouvindo não escutam e aqueles que entendem não compreendam” (Mt., 13,13).

Explica-se ainda porque a honestidade, a retidão e a justiça trazem a paz ao homem e porque, ao contrário, a injustiça lhe traz inquietação e guerra. Pois na justiça tudo no homem está em harmonia, a vontade com o conhecimento, o conhecimento direto com o reflexivo; na injustiça há um contraste contínuo da vontade contra o conhecimento, da reflexão contra o conhecimento direto. Há no homem o conhecimento das coisas e, todavia, o homem o nega, não quer que ele exista. Para fazer isso, ele deve lutar contra si mesmo, deve se ter em um contínuo estado de violência, porque de outro modo não pode destruir o que há em seu espírito, isto é, a apreensão da coisa; não pode anular a verdade, que o condena continuamente, e que testemunha contra ele, de que ele erra, que age iniquamente.

E todas essas observações dão maior luz àquele grande princípio moral de que já falamos, no qual tudo finalmente retorna ao RECONHECIMENTO voluntário daquilo que primeira e necessariamente conhecíamos, ao não negar a nós mesmos conhecer, ao admitir com uma vontade amiga o bem das coisas percebidas, reconhecimento e assenso que é o alegre tributo de obséquio e estima, que nós mesmos damos às coisas e à sua bondade. 
Nota

(I) N.T. A vontade no lugar da razão. 


\section{Artigo V}

\section{A verdade é o princípio da moral}

Diz-se verdade a um exemplar, tipo, norma ou regra da mente, à qual se comparar e verificar o que lhe deve ser conforme (10). Esse tipo é a verdade das coisas que a ele se referem: uma coisa é verdadeira se conforme a sua verdade, se é conforme àquele seu tipo. Do contrário é falsa.

O ser é o exemplar primeiro, universal, a regra suprema de todos os juízos. É, portanto, a verdade primeira e universal.

Toda ideia é verdade em relação à coisa; a coisa é verdadeira se corresponde a sua ideia.

O conhecimento direto é somente a ideia da coisa e é, portanto, a verdade: os juízos da reflexão são verdadeiros se se conformam à sua verdade, ou seja, com o conhecimento direto; são falsos se dela se desconformam: pois, com esses juízos, o que faço é afirmar que a coisa concebida é assim e assim; a coisa concebida é, pois, a norma desses juízos e a coisa concebida não é senão a ideia, o conhecimento direto.

Portanto, quando não reconheço fielmente os valores de uma coisa por mim conhecida, mas, em vez de os reconhecer como estão na minha mente, eu os invento ou os finjo, digo o falso para mim mesmo e essa mentira é o ato imoral de que falamos.

Portanto, é claro que a verdade é o princípio da moral e que o reconhecimento da verdade (conhecimento direto) é o sumo gênero dos deveres, o ato próprio e essencial da moralidade. Logo, não deve espantar que a palavra verdade, nas divinas Escrituras, seja frequentemente sinônimo de bondade moral e a palavra mentira sirva para indicar igualmente qualquer pecado. Todo pecado se reduz a uma mentira que dizemos a nós mesmos: antes de agir mal exteriormente, precisamos conseguir nos enganar, seduzirmo-nos interiormente; e uma palavra interior falsa e mentirosa é o fundamento de todos os nossos desregramentos exteriores.

Por isso, o homem reto e caro ao Senhor é descrito com suma sapiência com estas palavras: "aquele que fala a verdade em seu coração" (11). E é verdadeiro que "a lei do Senhor é a verdade" (12). 


\section{$\underline{\text { Nota }}$}

(10) N.A. Sobre a definição do vocábulo verdade raciocina-se nos Opuscoli Filosofici, vol. 1, pág.98, e no Nuovo saggio, vol. 3, págs. 15 e segs. e 70 e segs.

(11) N.A. S1, 14.

(12) N.A. S1, 14. 


\section{Artigo VI}

\section{Como se manifesta em nós a força da obrigação}

Tal é, como a descrevemos até agora, a eficácia de nossa vontade. Ela ou se rende à verdade ou a rejeita, substituindo-a pela ficção, a que depois honra e reverencia como se fosse a verdade.

Mas quando tenho a ideia da coisa (conhecimento direto) e, todavia, desconheço e nego para mim mesmo o que a coisa tem em si de valor, fazendo uma estimativa falsa e injusta dela, sinto fazer o que não convém, sinto um remorso: reconheço uma torpeza no meu agir. Este remorso, esta consciência de agir mal é uma manifestação da força obrigacional.

Verdadeiramente, quando conheço uma coisa (com conhecimento direto), não há nada que me force a dizer a mim mesmo que não a conheço, ou que a conheço diferentemente da maneira como a conheço. O que faço com a minha reflexão? Nada senão dizer a mim mesmo: "tal coisa tem tal natureza, tem tal ser, tais graus de ser, tais valores, é superior àquela outra coisa". O que significa esse discurso interior que faço a mim mesmo? O que estou dizendo com isso? Estou confessando a mim mesmo que conheço a coisa daquele modo; estou me dando conta de meu próprio conhecimento; estou dizendo: "refletindo sobre o conhecimento que tenho de tal coisa, descubro que eu, pensando na tal coisa, penso nos tais graus e modos de ser, aos tais e tais méritos dessa coisa sobre aquela outra". A minha estimativa da coisa, então, funda-se apenas sobre o conhecimento precedente que tenho dela, é só uma análise, uma confirmação, uma declaração voluntária que faço a mim mesmo daquilo que já conheço, em uma palavra, um reconhecimento.

Ora, não é evidente que, se nego a mim mesmo conhecer o que conheço, estou mentindo a mim mesmo? Não é evidente que nada me pode coagir a dizer que conheço uma coisa de um modo, se desse modo não a conheço? Dizer que a desconheço, se a conheço? Que, portanto, é totalmente voluntária essa mentira, é toda ela o efeito da minha eficácia interior, com a qual ou posso de bom ânimo assentir ao que conheço, reconhecendo-o, ou posso com um ânimo adverso rebelar-me e recusar-me a reconhecer o que conheço, a dizer a mim mesmo saber o que sei, querendo ou não querendo sabê-lo?

Eis a conveniência de pronunciar e dizer a mim mesmo conhecer o que conheço, nem mais nem menos, de fazer essa deposição daquilo que me é conhecido sem alterálo ou desfazê-lo, e a inconveniência de fazer o contrário é clara e evidente por si só. 
Ora, é exatamente essa conveniência que sinto de fazer isso a obrigação moral primeira, por si claríssima, razão e fonte de todas as outras obrigações: essa conveniência é o que forma o honesto, essa inconveniência é o que forma o torpe moral.

Digo que a obrigação nessa primeira operação de reconhecer aquilo que se conhece é por si só evidente, não havendo necessidade de demonstração, pois, se conheço uma coisa e digo a mim mesmo não a conhecer, estou em contradição comigo mesmo, oponho-me a mim mesmo, e é justamente na contradição e na oposição que está a inconveniência em que fizemos consistir o mal (13). Sou, portanto, o autor do mal em mim, porque, com a minha vontade, sou o autor da contradição e da oposição em mim mesmo, isto é, da oposição entre o reconhecimento e o conhecimento e, num ser inteligente, ser o autor voluntário do mal é o que faz o homem moralmente mal.

Essa contradição e essa oposição que coloco em mim mesmo quando creio e finjo para mim um conhecimento reflexivo contrário ao conhecimento direto está excluída da ordem do ser, já que a ordem é o sinônimo da harmonia e do acordo, nascendo da exigência íntima do conhecimento direto, pois o conhecimento direto, que é o tipo a que se deve conformar o reflexivo, é imutável, é a própria verdade, como dizíamos, imune à ação da vontade humana e que, portanto, ela, por sua própria natureza, exige não ser voluntariamente desconhecida, mas sim bem reconhecida tal qual ela é. Há necessidade de prova de que, querendo dizer a nós mesmos o que conhecemos, devemos dizer o que conhecemos? Já não chegamos ao princípio de identidade? Não reduzimos com isso a ciência dos costumes a sua primeira razão? Não colocamos desse modo o princípio da moral em uma evidência plena? Se dizemos não conhecer o que, contudo, conhecemos, se dizemos conhecer o que não conhecemos, não fazemos com isso um esforço para fazer com que não seja o que é e que seja o que não é? De tal modo, não operamos contra o princípio de não contradição, que diz que “o que é não pode não ser e o que não é não pode ser”? Não nos opomos com isso ao ser, pois nos esforçamos para fazer com que não seja aquilo que, todavia, é, e que seja aquilo que, todavia, não é? A nossa vontade, assim, não se insurge e investe contra a verdade para destruí-la? Não se insurge e investe contra o ser para destruí-lo? Ela quer, assim, o mal, pois busca a destruição do verdadeiro e do ser, o que significa dizer porque busca, no que lhe toca, a destruição do bem. É nessa operação violenta da vontade que fizemos consistir a essência da imoralidade. 
Nota

(13) N.A. Cf. cap. II, art. II. 


\section{Artigo VII}

\section{Objeção resoluta}

À doutrina que exponho vai se opor que faço atuar a liberdade humana sem uma razão suficiente.

Respondo à objeção do seguinte modo:

A liberdade humana, dirão, age sempre segundo uma razão suficiente. Bem, eu pergunto: essa razão suficiente determina a vontade humana necessariamente, isto é, de modo tal que ela não possa atuar? Nesse caso, destruiu-se a livre vontade. Ou então, ela determina essa vontade, mas de modo que a vontade possa não atuar ou ao contrário atuar? Nesse caso, conservou-se a liberdade do homem, mas com isso se chegou propriamente ao meu sistema.

É falso que eu faça agir a vontade sem a razão, enquanto de fato defino a vontade como uma potência de agir segundo uma razão: é esse o caráter que a especifica, que a distingue do puro instinto. Em seguida, porém, observo que, dadas mais razões para atuar, ela pode escolher, pode torná-las mais ou menos eficazes sobre si, pode torná-las predominantes, com aquele juízo prático do qual já falei. Nunca atua sem uma razão, mas é essa razão que ela mesma julga, que declara eficiente e assim a torna tal; é ela em suma que se deixa, que se faz mover por aquela razão ou que a ela resiste, colocando em seu lugar, com a sua livre eficácia, uma outra razão.

Para sair do indeterminado e entrar no caso das ações humanas: digo que o homem recebe involuntariamente as percepções e ideias das coisas (conhecimento direto). Quando se põe a fazer uma estima dessas coisas que conhece, ele bem se dá conta de que não deve dissimular nada do que conhece a si mesmo, ele sente-se obrigado a reconhecer simples e puramente a verdade conhecida. Essa verdade, essas coisas por ele percebidas, são a razão segundo a qual sabe dever julgar e, logo, sente a obrigação de dever proceder retamente nesse juízo. Mas ocorra que lhe seja apresentado (por acaso inicialmente) algum interesse sensível ou algum pensamento de orgulho, que o faça crer útil a ele desconhecer aquilo que conhece e julgar as coisas por ele conhecidas de um modo contrário ao seu conhecimento: então, fez-se presente a ele uma nova razão. Ocorrido isso, ele tem duas razões contrárias presentes em seu espírito: a primeira razão é de se render à verdade, à honestidade; a segunda é seguir o prazer, rebelando-se contra a verdade e desconhecendo-a.

Ele sabe dever seguir a primeira, sente sua íntima conveniência, a obrigação absoluta e imutável. 
Todavia, essa obrigação não o força mecanicamente, como também não o força o pensamento do deleite que se opõe a ela: ele é livre, ele pode fazer aquilo a que se sente obrigado, ou violar o dever para seguir a má propensão. Ele é o árbitro entre o bem e o mal, ele escolhe; é então que ele forma o juízo prático, com o qual estima melhor seguir a obrigação, ou estima melhor para ele infringi-la. No primeiro caso, age retamente; no segundo, peca.

Nesse juízo prático consiste a eficácia da sua vontade: em um ou outro caso, ela atuou segundo uma razão: mas pré-escolheu qual das duas razões quis e, dessa escolha, não há outra razão além da eficácia interior da própria vontade, poder admirável que tem o homem, com o qual não é movido, mas move-se a si mesmo. É uma espécie de potência criadora, em que o homem completa a razão suficiente: tal é ainda a descrição que fazem as Escrituras da liberdade humana: “A princípio Deus criou o homem e o entregou a seu próprio conselho (14). Deu-lhe também os seus mandamentos e preceitos, dizendo-lhe: Se quiseres guardar os mandamentos e manter a tua fé que me é grata, os mandamentos te guardarão. Assim ele te pôs diante da água e do fogo: ao que preferires, estende a mão direita. Diante do homem está a vida e a morte, o bem e o mal: a ele será dado o que ele quiser" (15). 


\section{$\underline{\text { Notas }}$}

(14) N.A. O conselho (*) é uma operação intelectual, o que está de acordo com o que dissemos, que a volição se faz mediante uma reflexão, da qual o assenso da vontade é, por assim dizer, a conclusão.

(15) N.A. Eclo, 15, 14-17.

(*) N.T. Na tradução dos versículos do Eclesiástico, mantivemos o termo "conselho", seguindo a expressão de Rosmini. Nas traduções portuguesas, costuma-se traduzir a expressão por "juízo". De fato, "consiglio", em italiano, admite ambas as traduções e "conselho" em português ambos os sentidos. 


\section{Artigo VIII}

\section{Corolários acerca da liberdade da vontade}

Dessa doutrina nascem alguns corolários importantes aceca da liberdade da vontade humana, que são os seguintes:

1) A liberdade da vontade é menor ou maior, de acordo com a força dos estímulos, que se constituem (16) mais ou menos facilmente em outras tantas razões de agir.

2) Se no homem existisse apenas o conhecimento direto e não se apresentassem estímulos contrários, isto é, que tendessem a constituir-se na mente humana em iguais razões de agir contra as normas do conhecimento direto, a vontade estaria em seu grau máximo de liberdade: porque o conhecimento direto não prende, mas somente dirige a vontade.

3) A boa vontade, isto é, que se adapta e assente com simplicidade ao conhecimento direto, com esse seu assenso e gozo que extrai por iniciativa própria da verdade, nem bem prende, nem diminui indevidamente a própria liberdade.

4) Quando a vontade começou a dar lugar a razões contrárias ao conhecimento direto, razões fictícias e, pois, falsas, ela começou com isso a se prender, começou a perder danosamente a sua liberdade. Não pode mais, tão agilmente como antes, assentir e acomodar-se à verdade, até que só lhe restem razões de utilidade ilusória, contrárias à verdade.

5) Mesmo diante dessas falsas razões que tornou para si mesma mais ou menos fortes, a vontade retém um poder com o qual pode diminuir-lhes a força que ela mesma lhes deu, mas com a condição de uma certa sucessão de esforços e de um certo tempo, já que sua atuação é condicionada pelo tempo. 


\section{$\underline{\text { Nota }}$}

(16) N.A. Isso nasce devido à unidade do sujeito que sente e do sujeito que quer. $\mathrm{O}$ estímulo sensível age sobre o sujeito sensitivo; mas esse sujeito sensitivo é também intelectivo e, portanto, esse sujeito move a vontade para satisfazer também aos estímulos do sentido corpóreo. 


\section{Capítulo VI}

Das potências que concorrem para o ato moral

\section{$\underline{\text { Artigo I }}$}

Potências morais por participação e potência moral por si

O que antes dissemos demonstra que há duas espécies de potências morais: aquelas morais por si; aquelas morais por participação.

A potência que se pode dizer moral por si é aquela que preside o juízo prático; as potências morais por participação são aquelas que presidem os afetos e as ações exteriores.

As ações morais exteriores supõem a potência de agir no exterior e esta se torna uma potência moral quando é movida por um afeto moral.

$\mathrm{O}$ afeto moral supõe a potência dos afetos e esta se torna uma potência moral quando é movida pela estimativa prática.

A potência da estimativa prática, ou seja, do juízo, não se torna moral, mas é propriamente a potência moral por si mesma. Vejamos que potências têm relação com aquela que preside o juízo prático. 


\section{Artigo II}

\section{Intelecto moral}

Enquanto vê o ser, o espírito se diz dotado de intelecto. Mas quando considera esse ser no seu uso de nos servir de lei moral, ele pode apropriadamente ser chamado de intelecto moral.

O intelecto moral, portanto, é a potência da primeira lei moral. 


\section{Artigo III}

\section{Razão moral}

A razão é a faculdade de aplicar o ser e, assim, de tornar intelectivas as percepções, de delas distinguir as ideias, de integrá-las e conectá-las em juízos e raciocínios.

Portanto, a potência de aplicar o ser enquanto lei moral pode ser chamada de razão moral.

A razão moral, pois, é aquela potência que forma as percepções e as ideias, consideradas estas como igualmente leis morais; aquela potência que deduz as leis menores da lei primeira e universal, e que define quais sejam as ações justas e quais as injustas: resumindo, a razão moral é a potência dos juízos morais. 


\section{Artigo IV}

\section{Razão eudemonológica}

A razão se chama eudemonológica enquanto raciocina sobre aquilo que se refere a nossa felicidade; ou seja, ela é a potência de aplicar o ser considerado como regra, de acordo com a qual julgar o nosso próprio bem subjetivo. 


\section{Artigo V}

\section{Razão prática}

Finalmente, a razão prática é aquela eficácia da reflexão voluntária, pela qual formamos a estimativa predominante para um objeto e, consequentemente, por qualquer ação que a ele se refere; isto é, aquela estimativa que é seguida imediatamente pelo surgimento do amor predominante, que é também seguido pelas ações exteriores (1).

Essa potência de formar a estimativa predominante, ou juízo prático, em que o afeto se apoia como em seu fundamento, por assim dizer, ora dá predominância a razões morais, ora a razões puramente eudemonológicas; essa potência é um árbitro e calcula uma e outra espécie de razões, isto é, as morais e as eudemonológicas, e o resultado do cálculo que faz dessas duas espécies de razões é propriamente o juízo prático, a estimativa prática, ativa e motriz dos afetos.

A razão prática é, portanto, quase um árbitro entre a utilidade e a honestidade das ações e julga aquilo que naquele instante nos é melhor fazer; esse juízo do que nos é melhor fazer no presente é tirado tanto de razões morais, quanto de razões eudemonológicas, ou melhor, ora se funda nas primeiras e ora nas segundas. Na razão prática, portanto, se compreendem as duas razões, ética e eudemonológica, as quais são ambas teoréticas e especulativas, e se reduzem à prática com uma função própria do espírito, que constitui a razão prática propriamente dita; o que ocorre quando o homem está prestes a agir e lhe são apresentados tanto os motivos morais quanto os eudemonológicos, e ele os recolhe, confronta, lhes atribui peso, e balanceia o peso que lhes atribuiu, para afinal pronunciar internamente aquele juízo operativo, a que seguem imediatamente o afeto e a ação, como um efeito segue sua causa ou como um fruto brota de um galho. Esses últimos juízos, portanto, que precedem imediatamente as ações do homem são os que se podem chamar verdadeiramente de práticos, distinguindo-se dos especulativos, e a faculdade que os preside diz-se razão prática. 


\section{$\underline{\text { Nota }}$}

(1) N.A. Uma só é a faculdade do intelecto e uma só a faculdade da razão. Todavia, essas faculdades têm diversas funções. Por uma questão de brevidade e simplicidade, costuma-se dividir essas faculdades de acordo com suas várias funções em outras tantas faculdades particulares a elas subordinadas e nelas contidas. Assim, em vez de utilizar essa frase incômoda "a razão enquanto julga as coisas morais", é melhor abreviar e dizer simplesmente "a razão moral". Convém ter isso em mente para não cair em erro formando muitas faculdades distintas de uma só faculdade. Como já observei nos Opuscoli filosofici, vol. 1, p. 106 (Milão, 1827), Kant incorre nesse erro, fazendo da razão prática mais um instinto do que uma verdadeira razão. Desse equívoco, encontrado no sistema kantiano e que é o motivo de muitas ilusões, pode ser causa a confusão que normalmente se faz entre razão prática e razão moral, as quais tenho o cuidado de separar diligentemente. A razão prática está intimamente ligada ao amor, que é o instinto da natureza intelectiva, sendo fácil tomar esse instinto pela razão prática dele próxima, embora instinto e razão sejam coisas essencialmente diversas. Quem tiver de meditar sobre as obras de Kant perceberá a importância dessa observação e como ela conduz a encontrar os sofismas com os quais ele quer reparar a insuficiência de sua razão teorética. 


\section{Artigo VI}

\section{A razão moral é a fonte das leis subordinadas à primeira}

Os juízos que a razão moral faz são as leis menores, que estão contidas na lei primeira e suprema, como as espécies se contêm no gênero.

A título de exemplo, quando julgo que a natureza racional é de tal modo digna de respeito que não posso considerá-la como um puro meio para os meus fins, sem ofender sua dignidade, porque também ela tem em si isso que é fim por si mesmo; então estou fazendo um juízo da razão moral. A razão moral faz esse juízo com a ideia do ser, pois tem com essa norma do ser mede os seres subsistentes, e calcula os graus, os modos, a quantidade do ser; assim percebe que o ente intelectivo é de tal modo e natureza que tem em si a excelência supracitada, a qual põe acima de todos os outros entes não intelectivos, que para ele têm ordem de meios e não vice-versa.

Ora esse juízo da razão moral se muda logo em um decreto, em uma lei moral, desde que se considere na sua força de obrigar, que manifesta. Coloquemos isso numa fórmula e sentiremos logo a verdade dessa afirmação: "O ser inteligente tem em si a natureza de fim e por isso deve ser reconhecido como tal”. 


\section{Artigo VII}

\section{Definição da consciência moral}

Se formo um juízo prático sobre motivos eudemonológicos e não morais, eu peco, e seguem a esse juízo afetos e ações imorais.

Mas, no mesmo tempo em que desse modo peco, tenho comigo mesmo a consciência de pecar e experimento sua amargura interior. E de onde vem esse conhecimento? O que é esse conhecimento, essa consciência?

Estou ciente de pecar porque sinto a força da lei, isto é, do conhecimento direto que é uma lei para mim e à qual não assenti de boa vontade, como devia, antes violandoa. Julgo, então, a mim mesmo, julgo que aquele juízo prático foi iníquo e imoral: esse juízo que faço de mim é o que chamo de consciência moral.

Segundo o meu modo de falar, que concorda com o do povo, a consciência moral não é, pois, um juízo prático, mas "um juízo especulativo sobre a moralidade do meu juízo prático e das suas consequências".

Diz-se comumente que devo agir de acordo com a minha consciência, mas o que quer dizer isso, senão que devo estimar e julgar as coisas pelo que valem, amá-las proporcionalmente e agir segundo esse amor bem ordenado? A consciência, pois, não é juízo prático, mas um juízo especulativo e moral, que determina como deve ser feito o juízo prático.

Daí advém que tal juízo não só acompanha, mas também precede o juízo prático e indica como ele deve ser feito; e ainda sucede o juízo prático, aprovando ou reprovando o juízo prático que foi feito; logo, costuma-se distinguir a consciência em antecedente, concomitante e consequente.

Creio que essa definição da consciência é capaz de dirimir muitos equívocos que espalham obscuridade e incerteza nos tratados de moral. 


\section{Capítulo VII}

\section{Dois elementos do ato moral}

\section{Artigo I}

\section{A lei e a vontade, os dois elementos do ato moral}

De tudo o que foi dito se conclui que o ato moral resulta de dois elementos, ou seja, 1) da lei e 2) da vontade que se conforma à lei.

A lei moral é o conhecimento direto das coisas, isto é, as ideias das coisas, das quais a primeira é a do ser em geral, forma de todas as outras, que por isso é também a primeira lei e forma todas as leis.

A vontade se conforma à lei com um ato de reflexão voluntária (1), com a qual se reconhecem as coisas como estão no conhecimento direto, nem mais nem menos, reconhecimento voluntário que é um juízo, uma estima que se faz das coisas proporcionada ao valor verdadeiro delas, sem nenhuma alteração arbitrária, comprazendo-nos nós em tal ato de todos os valores que há nas coisas e a eles nos rendendo de bom grado, consentindo, em suma, sem repugnância nem resistência, à verdade. Dessa estima veraz brota um prazer puro, que é o prazer da verdade, prazer que dá origem a um amor razoável, a um amor de todas as coisas sem nenhuma exclusão, segundo o seu mérito. Em consequência desse amor o homem age exteriormente e age com retidão se esse amor é reto e ordenado.

Por isso, se esses dois elementos formam o ato moral, convém que quem escreve um tratado de Ética os estude diligentemente, deduzindo desse princípio duplo toda a disciplina moral.

Creio que não será inútil fazermos algum aceno a semelhante dedução e digo só um aceno porque não é meu objetivo estender esse pequeno livro de modo a transformálo num tratado de Ética, mas indicar os fundamentos dessa ciência fundamental da vida. 


\section{$\underline{\text { Nota }}$}

(1) N.A. Essa reflexão sempre voluntária é ainda mais ou menos voluntariosa, o que é um novo elemento segundo o qual calcular a perfeição moral do agente, como logo diremos. 


\section{Artigo II}

\section{Da imputabilidade das ações}

As ações morais se imputam a seu autor, considerando-se em seu louvor ou em sua censura.

Essa imputação é maior em razão dos dois elementos acima indicados, isto é, quanto mais grave é a lei e quanto mais concorreu a eficácia da vontade no ato bom ou culpável.

A eficácia da vontade se mede tanto pelo grau da intenção com a qual a vontade passa ao ato, como do grau de liberdade de que ela goza ao fazê-lo. 


\section{Artigo III}

\section{Distinção entre o pecado e a culpa}

A má ação, portanto, tem duas referências, uma à lei que é violada; outra à livre vontade que a viola. E daqui decorre a distinção que faz São Tomás entre pecado e culpa.

Para o santo Doutor, a noção de pecado consiste num ato da vontade que declina da lei e põe, ao contrário, a noção de culpa em ser essa vontade livre. Pois se a vontade declina da lei necessariamente, mas não livremente, esse seu ato é sim um ato moral e, nesse sentido, um pecado, porque existem todas as duas condições para ser assim, isto é, a vontade e a lei; mas a culpa não pode ser imputada, porque não foi a livre vontade do homem que a cometeu. Ouçamos as próprias palavras do santo Doutor:

"Como a noção de mal é mais extensa do que a de pecado, assim também a noção de pecado é mais extensa que a de culpa. Por isso um ato se diz culpável ou louvável quando imputado a quem o pratica. De modo que louvar ou culpar é somente imputar a alguém a bondade ou a malícia de sua ação. Então, o ato se imputa a quem o pratica quando aquele ato está de tal modo em poder dele, que ele é senhor de seu ato, o que ocorrerá em todos os atos voluntários (2), pois, pela vontade, o homem é senhor de seus atos. Daí decorre que o bem e o mal só têm razão de louvor e de culpa nos atos voluntários (livres) e nesses atos, portanto, o mal, o pecado e a culpa são a mesma coisa" (3). 


\section{$\underline{\text { Notas }}$}

(2) N. A. O santo fala de uma vontade livre como mostra o contexto.

(3) N. A. Suma Teológica, I.II, q. 21, art. 2. 


\section{Artigo IV}

\section{Da bondade moral do produzir e da bondade moral do aperfeiçoar}

Vimos existirem duas maneiras de bem, bem substancial e o bem de perfeição. Se esses bens são obra de uma vontade, são bens morais, já que o bem se diz moral quando é produzido por uma vontade, portanto, haverá no sujeito volitivo uma bondade que chamarei do produzir e uma que chamarei do aperfeiçoar.

Essas duas bondades morais são, porém, de uma índole muito diversa entre si. Na produção do bem substancial não preexiste nenhum ser real, preexiste apenas a possibilidade, a ideia daquele ser que será produzido.

Ao contrário, na produção do bem de perfeição, preexiste aquele ser sobre o qual se exercita o ato de bondade, um ser real, término da vontade e do amor.

Um ser possível, sendo somente uma ideia e, em si mesmo, sendo um nada, não pode se tornar término da vontade em si mesmo: ele é apenas a lei, a norma, a medida, por meio da qual se pode conhecer, julgar e medir o ser subsistente: só para esse último a vontade se leva; neste, como em seu escopo, termina o juízo prático da vontade.

Daqui se vê que o ser possível, sem a correspondência de um ser subsistente, não pode induzir obrigação moral, nem pode dar lugar a um juízo moral, de modo que ao juízo são sempre necessários dois elementos, isto é, o meio com que se julga, que é o ser possível, e a coisa que se julga, que é o ser subsistente.

Portanto, para as coisas meramente possíveis, nenhuma obrigação pode existir; ninguém pode ser obrigado produzi-la e nisso consiste a liberdade moral.

É evidente, portanto, que o criador não é forçado por uma necessidade moral a dar existência a sua criatura, pois esta, antes mesmo de existir, nada pode exigir do criador.

É ainda evidente que o homem não tem uma necessidade moral de gerar outros homens, os quais, na medida em que ainda não são, não podem formar o objeto de nenhum dever, se também não se querem supor deveres para com vãs criações da imaginação.

Em uma palavra, a ausência de bem substancial não é nem mal, nem bem; é uma simples negação e não uma privação, e a negação não supõe nenhuma ação que a produza e, portanto, nenhum autor moral da mesma. 


\section{Artigo V}

\section{Da gratidão}

Contudo, apesar de a produção do bem da existência não nascer de nenhuma necessidade moral, quando um ser inteligente é produzido, ele é então, a partir do instante em que é, um bem para si mesmo, e deve, portanto, ser grato a quem foi a causa voluntária do bem de existir que ele tem.

Talvez se procure como isso se liga aos nossos princípios; o que é a gratidão, como nasce em nós semelhante dever.

A gratidão é um sentimento misto de mais afetos, que não é tão fácil de analisar; todavia arrisco-me a dizer o suficiente para saber como esses afetos constituem a matéria de um dever moral.

Eu me amo a mim mesmo, sou um bem para mim mesmo: nada nisso ainda é moral: este é um instinto, um bem subjetivo. Todavia, sei que existo não por mim mesmo, mas pela vontade de um outro ser que me deu a existência. $\mathrm{O}$ amor que tenho para comigo mesmo, para com a minha existência, se estende naturalmente para a causa que me produziu e a considero como boa para mim, porque origem do meu bem, então amo também a ela, porque toda coisa que se estima boa se ama.

Esse sentimento natural é conforme a verdade, pois é verdadeiro que eu seja um bem para mim mesmo e que a causa que me produziu seja boa relativamente a mim; portanto devo julgá-la e estimá-la assim, porque a concebo e ela é tal efetivamente.

Portanto, decorre daí a consequência que aquele que cria, ou aquele que gera, não se torna, com o ato de criar ou gerar, melhor em si mesmo, pois no seu agir não há nenhuma lei moral que aprove ou desaprove o praticar ou não praticar aquele ato, não existindo outra lei senão aquela que vem do ser subsistente por nós percebido, que ainda não é: falta, por isso, um dos dois elementos necessários ao ato propriamente moral; que é produzir um ato de pura vontade, um ato perfeitamente livre quanto ao fazer ou não fazer. Não obstante, depois de criado ou gerado o ser inteligente, aquela sua causa adquiriu uma nova bondade relativa a esse ser: uma relação de bondade que, sem mudar o estado moral do agente, produz, contudo, um dever no ser que recebeu a existência.

Ainda uma observação sobre os afetos contidos no sentimento de gratidão. Esse sentimento nasce do conhecimento que o homem tem de haver recebido um bem, de ter sido beneficiado. Ora, receber bens não põe nenhuma dignidade moral em quem os recebe, pois ocorreu apenas um aumento de bem subjetivo. E, se os bens dados são de 
perfeição, em tal caso, a dignidade moral é toda de quem os dá, sendo esses bens objetivos para quem os produz e não para quem os recebe, para os quais são subjetivos.

Ora, o homem nascido para a virtude, dotado da consciência que lhe obriga a dever-se elevar ao bem moral, deve ressentir no benefício, se não é um depravado, dois afetos a um só tempo nobres e dignos, sugeridos mesmo por aquela razão que nele fala uma linguagem de todo desinteressada e generosa.

O primeiro desses dois afetos deve ser de estima e de amor para com a dignidade moral de seu benfeitor e este deve ser naturalmente um afeto alegre e cheio de gáudio, se a má vontade não o combate, mas o favorece. O outro deve ser um sentimento de uma tal vergonha, por considerar ter recebido em vez de dado; sentimento que, se consentido pela vontade e não combatido por ela, se manifesta numa humilhação de si mesmo, com um sereno constrangimento interior, tanto mais digno de aprovação e louvor, quanto mais é querido com abandono pela vontade, porque é justo e conforme ao verdadeiro estado do beneficiado, embora contrário ao amor próprio, a esse amor desprovido de nobreza.

A ação da vontade pode secundar esses afetos justos e racionais, que nascem espontaneamente das ideias de beneficiador e de beneficiado (conhecimento direto); em tal caso, o homem exercita em sua plenitude essa cara virtude da gratidão; a ação da vontade pode também contrariar esses devidos afetos; e em tal caso, o homem peca de vários modos contra essa sua bela obrigação.

É a má vontade, que não quer sofrer a humilhação nem mesmo justa e devida, que leva alguns a esconder os benefícios recebidos, a encará-los como pesos insuportáveis, a esforçar-se por esquecê-los, por diminuí-los para si mesmos; é a má vontade de alguns que faz com que os benefícios a eles feitos sejam o erro imperdoável de seus benfeitores, que desconhecem, invejando o louvor que não querem lhes dar e que lhes é racionalmente devido. E porque nesse desdenhoso e soberbo vício da ingratidão há um tal pensamento de alteza moral, um pensamento que estima o valor de quem faz o benefício e não de quem o recebe, por isso a raça de ingratos de que falamos costuma se vangloriar orgulhosamente de sua própria ingratidão; não percebendo que receber o benefício não tem nada que pertença à dignidade moral; não reconhecer, porém, seu próprio e humilde estado, de quem recebe o benefício, é uma torpeza moral, pois é uma evidente injustiça. 


\section{Artigo VI}

\section{Da bondade moral do aperfeiçoar}

Repitamos: percebidas as coisas e extraídas as ideias das percepções, depende de nossa vontade reconhecê-las e delas se comprazer ou não. No primeiro caso a vontade é boa, no segundo, é má.

Onde a vontade reconhece os méritos das coisas percebidas e deles se compraz, nasce no sujeito volitivo o nobre deleite do bem e ali tem início o amor; onde resiste e contradiz as coisas para si mesma, a vontade sofre uma tristeza e ali está o princípio do ódio.

Mas a boa vontade, que reconhece com veracidade e se alegra com os méritos das coisas, ou mais propriamente das pessoas, pode fazer o seu ato de reconhecimento e de gáudio com maior ou menor expansão, plenitude e eficácia. Até onde, portanto, chega o dever, a obrigação moral? E onde começa o conselho, que é um bem maior que a obrigação? Pode haver excesso naquele ato, com o qual a vontade se transporta ao amor dos seres inteligentes?

Respondo que o ser é por si mesmo infinitamente amável e, portanto, quando se fala do ser como tal, não se pode pôr nenhum limite à eficácia da vontade que se volta para ele, que lhe reconhece os valores ilimitados e infinitos. Portanto, o aumento indefinido dos graus de eficácia da vontade que adere ao ser e dele se compraz, o aumento indefinido dos graus do amor, é só uma escala progressiva de um aperfeiçoamento indefinido do agente moral, que pode ascender continuamente na excelência moral, sem jamais chegar ao cume dessa ascensão que leva ao infinito.

Mas, se não pode existir nenhum excesso nos graus de eficácia com a qual a vontade procura o ser e nele se deleita, onde, então, está o vício da vontade, onde está a sua imoralidade? Na desordem com a qual se ama o próprio ser.

Já foi dito que a ordem é intrínseca ao ser, que quem ama o ser, ama necessariamente conforme a ordem do ser, que quem ama desordenadamente, não ama, mas verdadeiramente odeia o ser. E, em verdade, assim é. Se eu, por exemplo, amasse mais as coisas do que as pessoas, odiaria o ser. Pois em primeiro lugar eu tiraria das pessoas com a minha estimativa aquela parte de ser que as eleva acima das coisas; essa parte do ser, em vez de reconhecê-la, eu a anularia no meu pensamento reflexivo e voluntário, o que é destruí-la com o meu querer, odiá-la. Além disso, eu daria às coisas uma parte de ser que elas não têm, colocando-as acima das pessoas; e em tal caso, não é o ser verdadeiramente que eu amaria, mas, no lugar do ser, uma vã ficção minha, uma 
ilusão, um belo nada; e o amor do nada, o amor do falso ser, inclui o ódio do ser real, do qual se fugiu para enclausurar-se em uma vaníssima miragem.

O que é, portanto, intrinsecamente repugnante e contrário à verdade e à virtude é violar com a nossa estimativa e com o nosso amor a ordem do ser e, pois, o que é de dever, o que é de obrigação, se é que na nossa estimativa e amor não há desproporção, mas aquela proporção que corresponde perfeitamente à ordem do ser.

Daqui podemos extrair a linha demarcatória entre o que é obrigação e o que é uma bondade moral não obrigada.

A obrigação se estende até nos impor a distribuição de nossa estimativa e amor proporcionalmente, segundo a ordem do ser; de não antepor o que é posposto e não pospor o que é anteposto; além disso não se estende; não procede a determinação dos graus de estimativa e de amor que damos aos seres.

Os graus de estimativa e de amor que damos aos seres, suposta a proporção, ou seja, a ordem que neles há, podem ser maiores ou menores a nosso arbítrio; e quanto maior é a estimativa e o amor ordenado, tanto maior é a bondade moral de quem a possui.

Fica assim um campo amplíssimo para a bondade moral livre e espontânea, para a perfeição moral. Podem muitos homens seguir perfeitamente os seus deveres, conservando a ordem nos seus juízos, nos seus afetos, nas suas ações, e, entretanto, uns serem infinitamente mais perfeitos, mais excelentes do que outros, porque sua vontade é mais forte, sua ação mais intensa, porque com essa ação se conectam mais intimamente com o ser, nele se comprazendo, alegrando-se, saboreando-o, quase direi, mais avidamente, amando-o mais. 


\section{Artigo VII}

Dos deveres aos quais corresponde um direito aos homens em relação aos quais são imediatamente exercidos

Devemos amar os homens segundo a ordem: essa é a expressão que contém todos os deveres morais que temos para com os nossos semelhantes.

Contudo, isso não significa que, se nos é imposto esse dever, eles tenham em contrapartida o direito a nosso amor no sentido estrito e possam pretendê-lo como uma coisa própria; os senhores de nosso amor somos nós, e devemos prestar conta dele somente à lei e ao legislador supremo em que a lei está. Os homens podem, sim, lamentar-se se nós os odiamos, pois essa é uma injustiça que os tem por objeto; mas com esse ódio não lhes é retirada uma verdadeira propriedade, porque o meu amor não é propriedade deles e não são eles propriamente que o impõem a mim, mas sim a força da lei.

A palavra direito, como aqui a entendo, é a propriedade de cada um. Uma coisa de meu direito é o mesmo que uma coisa dita minha. Ora, se eu invado uma coisa de outrem, roubo-a e gasto-a; nesse caso faço um dano a outrem e leso um direito seu.

Portanto, os deveres para com os homens meus semelhantes, aos quais lhes corresponde um verdadeiro direito, estão compreendidos na fórmula "não fazer mal ao seu semelhante". Os homens têm direito somente a isso, que não lhes seja feito mal, que não lhes seja tirado algo de que são senhores; a mais não têm nenhum direito, no sentido definido.

Ter direito implica como consequência poder-se armar e defender com a força contra aquele que quer meter a mão em algo que nos pertence, quer nos fazer algum mal. Contra o ódio, enquanto permanece oculto dentro do peito, não podemos nos esquivar e, portanto, o amor e o ódio não são matéria de verdadeiro direito.

Os direitos dos homens, portanto, correspondem a deveres negativos ou proibitivos: além desses deveres proibitivos há também os positivos, como o do amor ao próximo, que não pode jamais ser propriedade de ninguém.

Não é, pois, o direito do homem que produz o dever; é a lei que intima ao dever: entre esses deveres há aqueles que, por um lado, proíbem fazer mal ao próximo, e, por outro, a própria lei permite ao próximo ter seu dano reparado, o que significa lhe dar direito sobre aquela coisa.

Os deveres para com os homens aos quais correspondem seus direitos são chamados de justiça (4), os outros se costuma chamar de deveres de caridade. 


\section{$\underline{\text { Nota }}$}

(4) N.A. Aqui a palavra justiça é tomada em sentido estrito: essa justiça é o fundamento do ius civile. 


\section{Artigo VIII}

\section{Dos deveres para consigo mesmo}

Deus e o homem, eis os objetos da moral, que tem toda por objeto o bem dos seres inteligentes (5).

Vimos que a natureza íntima da moral exclui o sujeito como tal, isto é, que o ato moral não é tal porque se refira a mim, porque me agrade, mas porque é conforme à verdade (conhecimento direto), a essa verdade que não tira sua eficácia de nenhuma pessoa humana, mas a tem em si mesma, a essa verdade que se nos apresenta como essencialmente impessoal.

Ora, essa importante observação exclui, talvez, os deveres para consigo mesmo?

Distingo: exclui os deveres para consigo mesmo, quando com isso se entende que não podem haver deveres que sejam produzidos diretamente pelo $E u$, sejam emanações desse sentimento. Mas, além disso, eu também sou um homem, eu também sou um ser inteligente, eu também sou objeto na contemplação da minha própria mente: também para esse objeto da minha mente, portanto, devo tudo o que devo à natureza humana. Os deveres para comigo mesmo não se encontram numa categoria diversa daquela em que estão os deveres para com todos os outros homens: foi a moderna filosofia dos sentidos, a vil filosofia do prazer, que, tendo invadido e arruinado o mundo, fez dos deveres para consigo mesmo uma categoria à parte, tornando-a a primeira e mais relevante classe de deveres e, finalmente, a classe universal, a única classe.

Mas não há, então, nenhuma diferença entre os deveres para comigo mesmo e os deveres que tenho para com meus semelhantes?

Nenhuma primitiva, essencial, intrínseca, mas intervém nesses deveres uma circunstância particular que é a seguinte.

A moral me diz que devo querer o bem da natureza humana, onde eu encontre essa natureza, seja em mim ou em outrem: essa é a lei comum, sem exceção nem privilégio; ela vale tanto para mim, quanto para todos os outros homens. Mas, além disso, como conheço o bem da natureza humana? Como conheço as exigências dessa natureza? Como posso saber o que a essa natureza ajuda ou prejudica, o que agrada ou desagrada?

Não posso saber tudo isso de outro, exceto de mim mesmo. Isso se tornou conhecido a mim pelo sentimento de mim mesmo; o $E u$, as suas modificações, as suas sensações, seus prazeres, suas dores, seus instintos, suas repugnâncias, suas 
necessidades, as satisfações de suas necessidades, são essas experiências que me fazem conhecer o que sucede nos meus semelhantes, o que é bem para a natureza humana, o que lhe é mal, o que ela apetece, o que rejeita, aquilo a que as forças dessa natureza tendem como sua perfeição, aquilo de que fogem como sua destruição. A ideia do homem (conhecimento direto), que me serve de regra para saber que bem devo desejar ou querer, eu a extraio de mim, do sentimento fundamental (6) ou substancial, pois é só o sentimento que percebe as subsistências e extraem-se as ideias das percepções. $\mathrm{O}$ sujeito, portanto, que é somente um sentimento, o sujeito, o Eu, só pode me dar experiência e, assim, a regra pela qual devo tratar os outros homens, os homens em geral; e é sob esse aspecto que o sujeito $E u$ está presente nos preceitos divinos da caridade, que não se dividem em três, mas são só dois e dizem “Amarás o senhor Deus com todo o teu coração, com toda a tua alma e toda a tua mente: esse é o preceito primeiro e máximo. O segundo é semelhante a esse: amarás o próximo COMO A TI MESMO”. E para que ninguém pense que existam outros além desses dois preceitos, o divino legislador acrescentou expressamente: "Desses dois preceitos dependem a lei e os profetas" (7).

O ti mesmo, portanto, entra nesses preceitos como o exemplo a partir do qual devemos amar os homens; não constitui um terceiro preceito; porque o ti mesmo exprime o sujeito, do qual não emana a lei moral, mas de onde vem o conhecimento do homem e de suas necessidades, já que nada saberíamos da natureza humana e das necessidades dos outros, se não tivéssemos tido a percepção de nós mesmos, a experiência do que a nós ocorre.

Disse que a lei que manda respeitar como fim a natureza humana não tem diferença essencial e exterior, se aplicada a nós ou a outros homens: há, porém, uma diferença acidental no modo de executá-la, que, todavia, não é uma exceção, uma lei superior, um privilégio que se arrogue o sujeito como tal. Essa diferença acidental e intrínseca na execução da lei de respeitar a natureza humana é a seguinte.

Posso ter mais ou menos ocasião de pôr em prática uma lei, posso ser mais ou menos ajudado pelo sentimento, pelo instinto, à execução fiel de tudo aquilo que me impõe uma lei; posso ter ocasião de executá-la mais plenamente, em maior extensão. Tudo isso se verifica da lei indicada relativa à natureza humana, quando a ela se aplica a mim, diferentemente de quando se aplica a meus semelhantes.

No que se refere a mim mesmo, tenho uma inclinação, um interesse, o máximo interesse, uma necessidade de executá-la ou, ao menos, de não violá-la inteiramente. 
Tudo isso pode talvez tolher a minha liberdade, que é um dos elementos do mérito, diminuirá ou tolherá o mérito na execução do dever, mas de qualquer modo permanece o dever, o dever que me comanda igualmente e onde eu o violasse, seria mais culpado quanto mais fácil fosse para mim não violá-lo, ou mais difícil violá-lo. Além disso, estou sempre comigo mesmo, mas nem sempre com os meus semelhantes, portanto, em mim posso mais frequentemente respeitar a natureza humana em ato, do que em outro. Finalmente, conhecendo todas as necessidades da minha natureza, posso mais extensamente praticar para mim a lei em questão. Essas três circunstâncias juntas dão uma índole especial aos deveres para comigo mesmo, parecendo que por causa delas a natureza me dá uma especial incumbência de ajudar a mim mesmo; dever de índole especial, digo, quando se considera a intenção da natureza e do criador, e se exercita esse dever para consigo com o alto fim de obedecer às disposições do Ser que fez todas as coisas. Porque é de uma lei mais alta, e não de um odioso privilégio em meu favor, que nasce uma certa diferença acidental entre o aplicar a mim e o aplicar a outrem a lei do respeito à natureza humana; dessa lei, que é expressa também nos preceitos evangélicos da caridade, declaração divina da lei natural, com a palavra PRÓXIMO, já que ninguém é mais próximo a si do que si mesmo; com a palavra PRÓXIMO se regula a execução da lei universal em um modo conforme às intenções da natureza e de Deus.

Proponho ainda uma outra reflexão que valerá talvez para ilustrar mais vivamente essa grande palavra evangélica: PRÓXIMO.

As necessidades e exigências da natureza humana ou são comuns ou particulares. As exigências comuns são aquelas que o homem tem sempre; as exigências particulares são aquelas que o homem tem como consequência de alguma relação acidental sua. A exigência de alimento, por exemplo, é comum e constante; a exigência que tem um pai de amar os seus filhos nasce da relação particular entre genitor e filho. Ora, a lei moral nos conduz a querer todo o bem possível ao homem, nos conduz a satisfazer, se nos é possível, todas as exigências dessa natureza: essa natureza nô-lo pede e esse pedido é exatamente a obrigação moral. É evidente, portanto, que um pai é obrigado a seguir o amor que a natureza lhe infundiu para com os seus filhos; o cuidado com os filhos é, pois, um dever que o pai exercita para consigo mesmo, mas mais verdadeiramente se diria para com a natureza humana, que em si mesmo encontra, com essa relação de paternidade. $\mathrm{O}$ instinto subjetivo que o leva a amar seus filhos e deles cuidar não é o mesmo que o dever; é a racionalidade desse instinto que torna isso dever no homem que, sem a razão, permaneceria puro instinto, como 
permanecem os animais. E o que quer dizer a racionalidade desse instinto? Quer dizer aquela necessidade de razão pela qual a natureza humana, concebida em nossa inteligência, quer ser reconhecida pelo que é e pelo que merece ser amada (pois se a respeitamos, queremos-lhe todo o bem possível). Ora, já que a essa natureza, onde estiver na condição de pai, apetece amar o filho, amar o filho é, portanto, um bem para ela, por isso deve seguir essa sua inclinação natural, essa sua exigência particular, deve querer esse seu bem. O pai, portanto, deve amar os filhos, mas não por um princípio subjetivo, não porque são seus, por um privilégio em seu favor, mas por um princípio geral, por uma lei comum, porque ele é pai, porque aqueles são filhos, porque esse amor não é para ele um bem em particular, mas um bem para a natureza humana, que ele deve respeitar e amar nele mesmo. Tudo que não nasce desse grande princípio, tudo o que lhe é a mais ou a menos, não é dever; será instinto natural e nada tem em haver com a moralidade.

O pai, portanto, vê nos seus filhos homens e, sob esse aspecto, lhes deve o que deve a todos os outros homens.

Mas o pai, além de ter a natureza de homem, tem a qualidade de pai: nessa qualidade, ele deve a si mesmo o amor, o cuidado e a educação dos filhos, ele a deve àquela reverência que é obrigado a fazer à natureza humana, naquela circunstância de pai, na qual essa natureza se encontra nele.

Esse dever de amar os filhos e cuidar deles é depois confirmado e sancionado por um outro dever superior, que é o de obedecer a divina providência na execução dessa incumbência que dela recebeu.

Os filhos, portanto, não têm outros direitos para com os genitores senão os direitos do homem; mas os genitores devem a si mesmos e a Deus o cuidado dos filhos não só como homens, mas como filhos.

Desse modo entra, quase se diria, na lei, o instinto subjetivo e daqui se vê qual é a natureza dos deveres para conosco mesmos e qual a força da palavra PRÓXIMO consagrada no Evangelho.

Pois, do que advém, então, que o pai deva a si mesmo o amor aos filhos e os cuidados com eles? Vem de haver um nexo natural entre ele e os filhos, porque a natureza de pai o liga a eles: em uma palavra, porque é PRÓXIMO a eles. A PROXIMIDADE é uma palavra admirável, que contém todas as relações naturais do homem e, assim, todas as exigências particulares. Mas vamos mais adiante e reflitamos. De todas as relações existe alguma mais estreita do que aquela que cada um tem consigo 
mesmo? Certamente não; aliás, essa é a união absoluta, se essa palavra é tolerável para exprimir uma relação de identidade. Convinha, então, tomar esse máximo entre as uniões como norma e regra absoluta e, assim fez o Evangelho, dizendo: "Amarás o próximo COMO A TI MESMO” (8).

Concluindo: a lei é universal: "deve-se respeitar a natureza humana, ou seja, querer à mesma o seu bem”. Mas qual é esse seu bem?

Esse bem da natureza humana é indicado por seus instintos naturais, por suas tendências naturais. Mas qual é a lei desses instintos, dessas tendências?

É aquele inclinar-se naturalmente mais a certas pessoas, do que a certas outras, segundo as circunstâncias em que alguém se encontra: essa inclinação amorosa a certas outras pessoas é chamada PROXIMIDADE pelo Evangelho. Onde começa essa proximidade, essa inclinação favorável a certas pessoas?

Pela inclinação que cada um tem essencialmente a si mesmo. Portanto, proximidade quer dizer apenas a vizinhança, a natural conexão conosco mesmo e Nós somos o ponto a partir do qual se mede a proximidade e a distância.

Todos os vínculos naturais dos homens entre si, portanto, são conservados e prescritos: já que se deve querer o bem da natureza humana, deve-se querer o que a natureza humana quer; e o querer natural dessa, o seu amor natural é exatamente aquilo que constitui o nexo, o vínculo de proximidade, segundo a explicação que dá o Evangelho da palavra PRÓXIMO na parábola do Bom Samaritano [Lc, 10, 25-37], na qual se vê ser o próximo aquele que mais ama e que mais socorre, relativamente ao amado, ao socorrido. É, portanto, perfeita e totalmente divina a enunciação da lei AMARÁS AO PRÓXIMO COMO A TI MESMO; e os deveres para conosco estão compreendidos nessa enunciação, e alocados no lugar que melhor lhes convêm. 


\section{$\underline{\text { Notas }}$}

(5) N.A. Deus reconhecido pela reflexão voluntária é o princípio da adoração e de todos os atos religiosos, bem como o motivo mais sublime do amor dos homens.

(6) N.A. A doutrina do sentimento fundamental é tratada no Nuovo saggio, vol. 2.

(7) N.A. Mt., 22, 37-40.

(8) N.A. Mt, 22, 39. 


\section{Anexo I}

\section{Glossário}

Historicamente, na Idade Média e no Renascimento, os glossários eram particularmente empregados nos textos filosóficos, para esclarecer o sentido de palavras antigas ou de difícil compreensão que neles se encontravam (Houaiss, 2012) e é esse mesmo o nosso escopo. Nosso glossário, contudo, não segue a ordem alfabética dos glossários convencionais, mas menciona palavras e expressões de acordo com a ordem em que elas aparecem no texto, com as devidas remissões ao final das explicações. Além disso, como se vê imediatamente a seguir, situa-se antes do texto de Rosmini, ainda que no final do nosso, uma vez que buscamos tanto esclarecer o percurso da nossa pesquisa, quanto o pensamento rosminiano.

1) Princípios da ciência moral: Passamos, palavra por palavra, o título italiano para o português. Convém, no entanto, apresentar algumas considerações sobre o título da obra, em especial quando se verifica que a tradução inglesa a intitula Principles of Ethics. Não há dúvida de que os Principi de Rosmini se enquadram no campo da filosofia que hoje se conhece por Ética, isto é, a "ciência da conduta" (Abbagnano, 2000). O roveretano, contudo, se filia à tradição latina, que, desde Cícero, traduz o grego êthos por moral: "porque toca aos costumes, que eles [os gregos] chamam êthos, e nós a essa parte da filosofia costumamos mencionar como filosofia dos costumes, mas convém que a enriquecente língua latina a nomeie de moral”.6.

Convém ainda esclarecer o emprego pelo autor do vocábulo ciência para designar a filosofia moral, que não corresponde ao sentido corrente do termo na atualidade. Ciência, para Rosmini, tem o significado antigo de episteme ou "conhecimento com garantia de validade, sendo, portanto, como conhecimento, o grau máximo de certeza" (idem Abbagnano). Nesse sentido, o oposto da ciência é a opinião ou doxa. Aristóteles procedeu uma distinção entre a filosofia teorética (Física, Metafísica e Matemática) e a filosofia prática (Ética e Política), reconhecendo, contudo, que ambas são ciência (episteme) pelo fato de buscarem o conhecimento de como as coisas são e a causa de como são. A diferença da filosofia prática para a teorética é que, para esta última, a verdade é um fim para si mesmo, enquanto para a filosofia prática a

${ }^{6}$ Cícero, Marco Túlio, Sobre o destino, tradução e notas de José Rodrigues Seabra Filho. São Paulo, Nova Alexandria, 2001. 
verdade não é o fim, mas apenas um meio em vista de outro, ou seja, da ação (Berti, 2002, p. 116).

2) Lei (legge): Ao se originar, na Grécia Antiga, a Ética se constituiu como pesquisa sobre o melhor modo de conduzir a vida e exercer a virtude, tendo em vista a felicidade (eudaimonia). Esse enfoque sofreu uma alteração substancial ao longo dos séculos que compõem a chamada Idade Média, sob a égide da reflexão teológico-filosófica cristã, com a Patrística e a Escolástica. Santo Agostinho, ao defrontar-se com o problema da vida feliz, definiu-a como a união da mente com Deus, no amor e no gáudio da verdade e do bem. Do mesmo modo, revisou a noção de virtude, concebendo como a principal das virtudes a caridade para com Deus e para com o próximo. Transformou ainda as principais virtudes pagãs platônicas e estoicas (prudência, justiça, fortaleza e temperança) em expressões do amor reto que ama Deus, as pessoas, as coisas criadas, segundo o grau de bondade que lhes pertence. Para viver a nova vida feliz - beata, em latim - necessitava-se do conhecimento que Deus tem de si mesmo e da ordem das criaturas. Tal conhecimento, presente em Deus sob a forma de lei eterna, é comunicado por via de iluminação a cada mente humana, como um conhecimento inato das razões eternas segundo as quais são regulados os atos da vontade. A lei eterna, além disso, é conhecida por via da Revelação, na lei escrita do Antigo e do Novo Testamento. A concepção agostiniana da virtude e da lei divina dominou a teologia medieval (Gilson, 2007). A expressão mais autorizada dessa concepção foram as Sententiae, de Pedro Lombardo, que se tornaram texto obrigatório a ser lido e comentado nas escolas teológicas, assim permanecendo até o século XVI. À colocação do foco da moral na lei, somou-se também, no final do século XII e na primeira metade do XIII, a iniciativa de alguns autores de desenvolver tratados articulados sobre leis, introduzindo, a partir do Direito romano, o conceito de lei natural e explicando a lei antiga e a nova. Ao lado disso, nas Universidades, ocorria o florescimento dos estudos do Direito romano e de Direito canônico. Dentre essas inciativas destaca-se o extenso tratado sobre leis composto por Jean de La Rochelle, que tem um quadro doutrinal agostiniano e uma concepção lombardiana: as leis e as virtudes são consideradas necessárias à formação dos costumes: as leis mostram o bem a fazer e o mal a evitar; as virtudes fornecem a capacidade de fazer o bem e evitar o mal. Assim, da lei natural e dos preceitos da lei divina, a consciência deduz as conclusões que guiam a ação. Essa teologia da lei acabou por desembocar numa nova concepção de lei moral, que se tornou o objeto a ser 
explicado ou investigado pela filosofia seja religiosa ou leiga. No âmbito leigo, o ápice dessa pesquisa é a Crítica da Razão Prática, de Kant. Todas estas observações, exceto a menção a Gilson, são um brevíssimo resumo do capítulo II, item 2 - A filosofia moral como pesquisa sobre a lei moral a ser observada, de Giuseppe Abbà (op. cit.). Elas explicam por que a obra de Rosmini se inicia falando em lei moral e contextualizam historicamente o pensamento do autor. Além disso, apresentam outros temas rosminianos que têm sua fonte em Santo Agostinho.

3) Ente/ser universal: No original italiano, Cap. I, art. II, o autor usa primeiro "ente em geral (ente in universale)" e depois "ser em geral (essere in universale)", conforme traduzimos. Com as duas expressões, a rigor, Rosmini se refere a uma mesma noção, a noção de "ser", que convém definir em seu sentido metafísico, para esclarecer também os dois modos de se expressar de nosso autor. Tanto em italiano quanto em português existem os dois termos, "ser" e "ente", sendo que o primeiro deles pode ser entendido como substantivo (e nesse sentido é sinônimo do segundo), quanto como verbo. Já em francês, a forma "être" é única tanto para designar o "ser" (verbo) quanto o "ente". Mas, de qualquer modo, ente é "o que é", ou, em latim, id quod est. A noção, portanto, não é simples, mas composta por um sujeito (id quod) e um ato (est). Ou seja, nessa noção estão presentes algo que é e o próprio é desse algo, mas esses dois elementos constituem uma unidade. Ao dizermos "ente" fazemos uma referência implícita ao "ser" e se ouvimos somente o verbo flexionado é, sentimos falta do sujeito, de quem ou o que é, do que decorre que "ente" e "ser" se implicam mutuamente (Alvira, 2014). Não é de espantar portanto, que, muitas vezes, "ente" e "ser" sejam usados como sinônimos, o que Rosmini faz em várias passagens ao longo do texto, embora use o termo "ente(s)" apenas 40 vezes contra o termo "ser(es)" 455 vezes (não estão incluídos nesta conta as vezes em que o verbo ser foi usado no sentido copulativo). De qualquer modo, a expressão "ideia de ente universal” só aparece neste artigo II do capítulo 1. Em todas as outras passagens, Rosmini fala em "ideia do ser".

4) Espécie/gênero (specie/genere): esses termos se definem mutuamente. Um gênero inclui duas ou mais espécies. Pertencem a um mesmo gênero os entes que apresentam traços similares compartilhados. Os gêneros vão se tornando cada vez mais gerais, até chegarem aos gêneros supremos (que não são espécies de nenhum outro), como a unidade e o ser (Zarander, 2007). A palavra gênero tem origem no grego genos, pelo 
latim genus, que significa "nascimento, descendência, origem; raça, tronco; descendente, rebento, filho". Seu étimo, provavelmente, é o nominativo plural genera (Hoauiss, 2012). Por sua vez, a palavra espécie tem origem no latim specie que significa "o conjunto de traços que fazem reconhecer qualquer objeto, vista, olhar, aspecto exterior, aparência, forma, figura" (Houaiss, 2012). No art. II do cap. I dos Princípios, Rosmini emprega os termos pela primeira vez.

5) Ideologia: Por "ideologia", Rosmini entende o estudo das ideias, tanto que a tradução inglesa emprega a paráfrase study of ideas. Esse é o sentido próprio do termo no início do século XIX, quando criado pelo filósofo e político francês Destut de Tracy (1754-1836), na obra Projets d'élements de ideologie (1801), para designar precisamente a "análise das ideias" [Zarader, 2007]. É nesse sentido que o próprio Rosmini classifica o seu Nuovo saggio sull'origine delle idee como uma obra de ideologia. Usar o elemento de composição logia para referir-se a estudos específicos é comum no vocabulário de Rosmini, que, nos Princípios da ciência moral, falará ainda em agatologia (estudo do bem), e eudemonologia (estudo da felicidade). De origem grega, os termos são homógrafos em italiano e português.

6) Perfeição (perfezione): O conceito de perfeição (do latim perfectio) significa, etimologicamente, o caráter daquilo que está completamente feito (factum), do começo ao fim, de parte a parte (per). Desse modo, ele implica a posição de um ente em seu estado pleno [Zarader, 2007]. O ente dispõe, potencialmente, de perfeições que ao longo do tempo se atualizam ou se realizam, aperfeiçoando-o. Por exemplo, a semente se torna planta, cujo caule pode se tornar um tronco e se repartir em galhos, a serem cobertos de folhas e, por fim, de flores, sendo considerados esses componentes do processo como perfeições da semente inicial.

7) Natureza (natura): como seu correspondente italiano, o termo português natureza se forma do substantivo latino natura. Natura é a tradução do grego physis e designa “o que é” uma coisa, seus caracteres próprios, originais - inatos quando se trata de seres vivos: para traduzir ousía ou hipóstasis, na ausência de essência ou substância, Cícero emprega natura; assim como para traduzir poiotes e idiotes emprega frequentemente natura em vez de qualitas e proprietas. E, por metonímia, natura designará a própria coisa dotada de caracteres próprios, considerada em geral ou em particular" [Fontanier, 
2009]. No artigo III, do cap. I em que se insere três vezes a N.T. (I), Rosmini usa três vezes o termo. Nas duas primeiras, no singular, refere-se à natureza em seu sentido físico e, na segunda vez (no plural), de modo metonímico, para referir-se aos entes ou seres inteligentes.

8) Sindérese (sinderesi): é um termo da filosofia escolástica que designa a capacidade natural do homem de conhecer imediatamente os princípios morais, de distinguir o bem do mal. Segundo Houais [2012], a etimologia portuguesa de sindérese é: "fr. syndérèse (c1470 sob a f. synderese) 'remorsos de consciência', emprt. ao lat.medv. synderesis, var. de synteresis 'conservação', t. da filosofia escolástica, proveniente do gr. synterēsis, ēos 'id.', der. do v. syntēréó 'conservar, preservar com cuidado'; em lat.medv., a hesitação entre - $t$ - e - $d$ - deve-se ao fato de se explicar o voc. tanto em função do v. suntēréō 'conservar' quanto em relação asyndiaírēsis, significando aproximadamente 'resumo, síntese dos princípios morais'; f.hist. c. 1543 synderesis, 1720 sindêresi, 1720 synteresis". Contudo, Albertuni [2010], sugere que o termo sindérese (do latim synteresis) foi introduzido casualmente nas especulações teológicas e filosóficas do período medieval, a partir da Glosa de São Jerônimo a Ezequiel (quinto livro profético do Antigo Testamento) e que o termo pode ser uma transcrição errônea do termo grego syneidesis, traduzido ao latim por conscientia, o que ensejou uma variedade de interpretações por diferentes escolas e pensadores, contribuindo sensivelmente para o desenvolvimento da psicologia moral na Idade Média. Ainda segundo Albertuni, não se tem notícia de referência ao termo synderesis ou synteresis na literatura patrística antes desse comentário de São Jerônimo (c. 347 d.C - c. 420 d.C.). Por se tratar de um texto pouco difundido em língua portuguesa, cremos adequado transcrevê-lo a seguir:

"Muitos, em conformidade com Platão, atribuem o racional da alma, o irascível e o concupiscível, que Platão chama de logikòn, thymikòn e epithymetikòn, ao homem, ao leão, ao touro...E admitem uma quarta parte, diferente de todas as outras três e elevada acima delas, que os gregos chamam syntéresin, centelha da consciência, que, mesmo em Caim, não se apagou no seu coração após sua expulsão do paraíso, e ela faz com que, embora vencidos que somos pelas volúpias ou pela loucura, enganados às vezes pela aparência de razão, nos sintamos pecadores. Eles atribuem esta, propriamente falando, à águia, a 
qual não se mistura com as outras três, mas as corrige quando erram, e da qual lemos na Escritura como o espírito que 'intercede por nós com gemidos inefáveis' (Romanos 8:26), pois 'Quem conhece a fundo a vida do homem é o espírito do homem que está dentro dele' (I Corintíos 2:11). Sobre o qual, Paulo escreveu aos tessalonicenses, 'rogo que seja conservado de modo irrepreensível com a alma e o corpo' (I Tess. 5:23) E, todavia, do mesmo modo, esta consciência, de acordo com aquilo que foi escrito em Provérbios: 'o ímpio quando viesse ao profundo dos pecados, despreza' (Prov. 8, 13), vemos precipitar-se e perder seu lugar em algumas pessoas, as quais não têm nenhuma vergonha nem discernimento em relação às suas ofensas, merecendo ouvir: 'Adquiriste uma cara de prostituta, nem com isso te enrubeceste' (Jerem. 3:3)" (Tradução de Carlos Alberto Albertuni).

Rosmini utiliza a palavra sindérese uma única vez, no art. III do cap. I, pág. 71, ao citar São Ivo.

9) Apetecer: Traduzimos appetisce por apetece (que aparece pela primeira vezno art. I do capítulo II), bem como todas as formas do verbo italiano appetire pelas formas do nosso apetecer. Por inexistência de um termo cognato em inglês, os tradutores ingleses empregaram desire e to desire, desejaldesejar, que seria plausível em português e até mais contemporâneo. Nossa opção, contudo, procura manter o sabor do original. Além disso, para esclarecer o significado dos verbos appetirelapetecer e ressaltar seu valor semântico, convém relembrar aqui sua etimologia: eles derivam do verbo latino appeto, is, ere, cujo radical pete tem provavelmente origem indo-europeia. São compostos da preposição ad e do verbo latino peto, is, ere, que significa "lançar-se sobre, atacar; dirigir-se para, tentar atingir, aproximar-se de; alcançar, atingir; buscar, procurar, pedir, solicitar, requerer; desejar, aspirar a, pretender; rogar, suplicar, pedir com instância”. (Vide nota I, pág. 93)

10) Possível/Subsistente (possibile/sussistente): Em sua acepção lexicográfica, possível é aquilo que pode ser ou não ser, que pode ou não acontecer. Contudo, no 
âmbito filosófico, essa palavra tem significados muito específicos, como se pode ver em Abbagnano [2000]. Sua origem se encontra no adjetivo dynatón deriva do verbo dynamai (posso), e Aristóteles dedicou várias páginas do livro nono da Metafísica à discussão de seus significados. O latim possibilis é um "decalque do termo grego" [Fontanier, 2009] e foi introduzido no vocabulário filosófico latino por Boécio [id.]. Por sua vez, o adjetivo subsistente deriva do verbo subsistir, cujo significado filosófico, também introduzido por Boécio, é "existir como substância, ou existir independentemente do espírito ou do sujeito pensante" (Abbagnano, 2000). No uso comum, em latim, o verbo equivale a persistir ou durar. No contexto do discurso rosminiano, os entes da ordem do possível são as ideias, que existem apenas na mente do sujeito, ao contrário das coisas que têm existência real e própria, alheia à mente, existindo como substâncias e sendo, por isso mesmo, subsistentes. As duas palavras são empregadas pelo autor pela primeira vez no art. I, do Cap. II.

11) Eudemonologia: formada a partir do grego eudaimonia (felicidade), em que dáimon significa espírito e eu quer dizer bem, é um termo cunhado por Rosmini que se encontra dicionarizado em italiano e designa o estudo da felicidade. Rosmini enfatiza a necessidade de distinguir a eudemonologia, que trata do bem subjetivo, da moral, que se refere ao bem objetivo. Contudo, ainda que se refira ao indivíduo ou ao sujeito, a eudemonologia, para o roveretano, não tem como objeto a mera satisfação pessoal ou o prazer dos sentidos, mas a beatitude e a contemplação de Deus. A palavra é empregada por Rosmini pela primeira vez no art. I do cap. III.

12) Substância (sostanza): No aristotelismo e na escolástica, realidade que se mantém permanente sob os acidentes múltiplos e mutáveis, servindo-lhes de suporte e sustentáculo; aquilo que subsiste por si, com autonomia e independência em relação às suas qualificações e estados. Opõe-se a acidente. (Houaiss) É nesse sentido que Rosmini emprega o termo a partir da pág. 91.

13) Essência (essenza): No aristotelismo, o conjunto de qualidades, propriedades e atributos universais que caracterizam a natureza própria de um indivíduo concreto, em oposição às alterações circunstanciais ou características excepcionais que possam eventualmente acometê-lo (Houaiss). Rosmini usa o termo pela primeira vez à pág. 94. 
14) Acidente (acidente): No pensamento aristotélico e escolástico, aspecto casual ou fortuito de uma realidade, que, por esta razão, é irrelevante para a compreensão do que nela é essencial e imprescindível (p.ex., a cor azul de um tecido é um acidente que, por sua presença, não transforma a natureza essencial desse objeto) (Houaiss). É nesse sentido que Rosmini emprega o termo, pela primeira vez, à pág. 134.

Resta acrescentar que existem outros termos técnicos empregados por Rosmini, que ele mesmo se encarrega de esclarecer em suas notas de rodapé, como é o caso de "noção" e "razão", cuja significação específica para o filósofo é apresentada por ele mesmo na nota (1) do primeiro artigo do capítulo I. Há também esclarecimentos do autor no corpo da obra, como ocorre no artigo I do capítulo VII, em cujo parágrafo final ele explica que, por "princípios", entende os fundamentos da ciência moral. 
Anexo II

Antonio Rosmini

\section{$\underline{\text { Principi della scienza morale }}$}

